\title{
Mining and Corporate Social Responsibility in Zambia: A case study of Barrick Gold Mine.
}

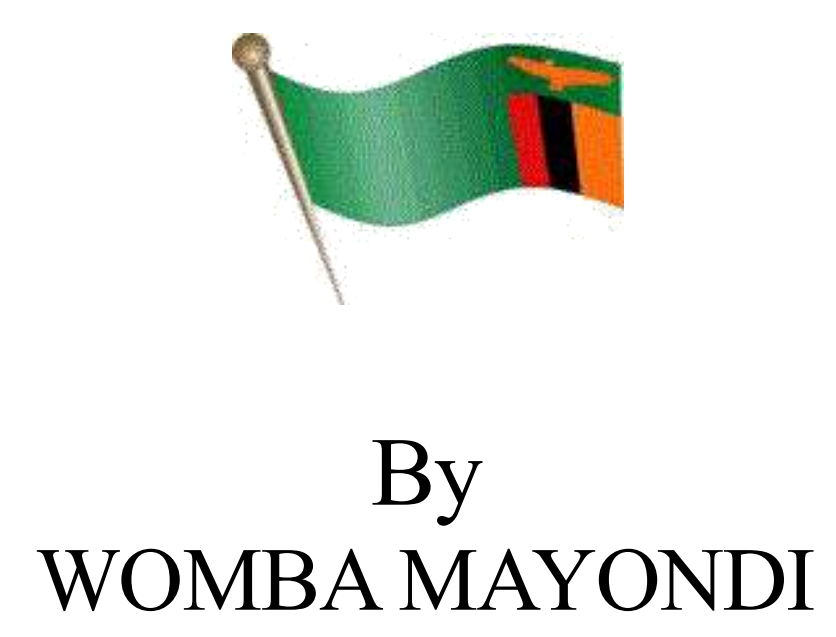

A thesis submitted to Victoria University of Wellington in partial fulfilment of requirements for the degree of Masters in Development Studies

Victoria University of Wellington 


\section{Table of contents}

\section{Chapter One}

\section{Introduction of mining and corporate social responsibility}

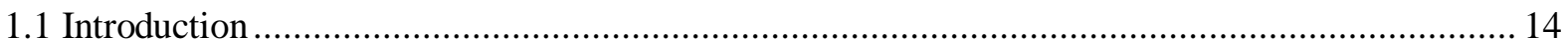

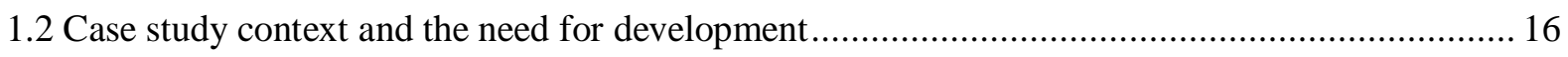

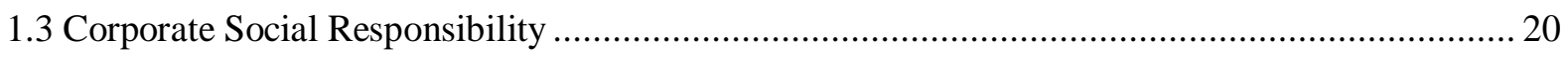

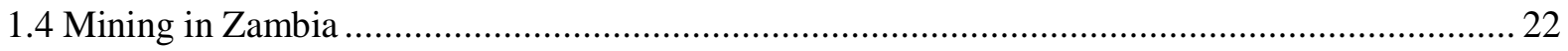

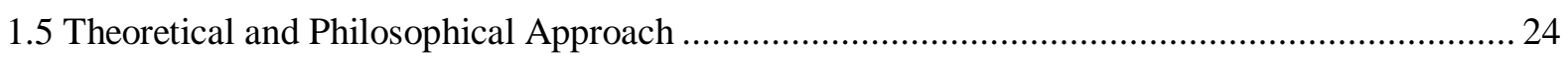

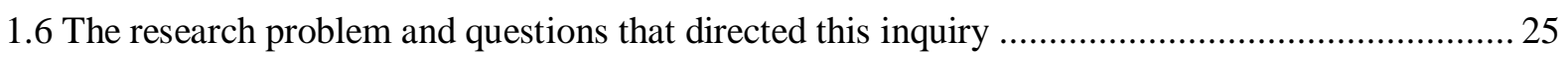

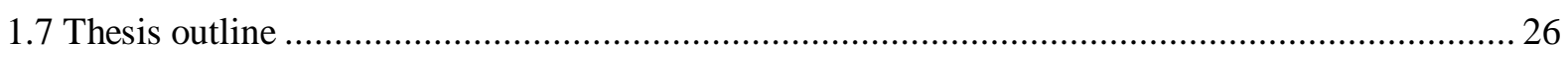

\section{Chapter Two}

\section{Epistemology, research design and methodology}

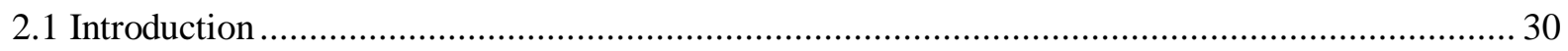

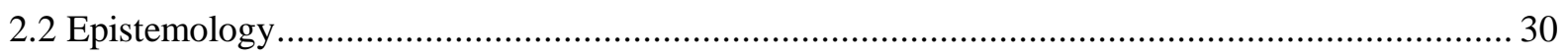

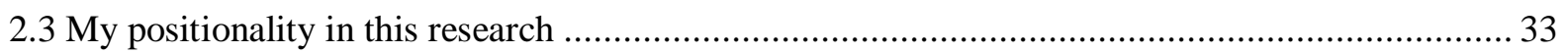

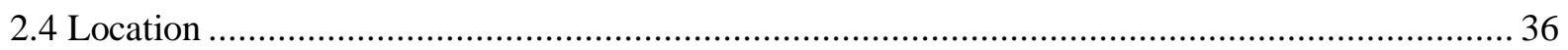

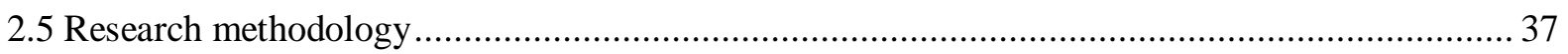

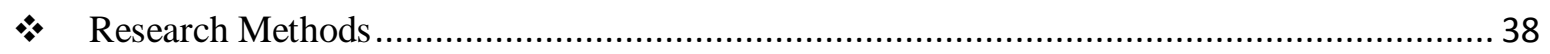

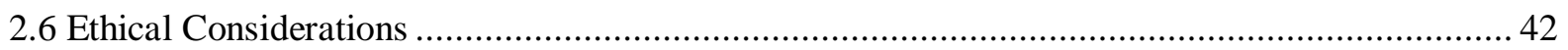

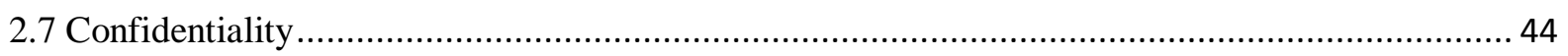

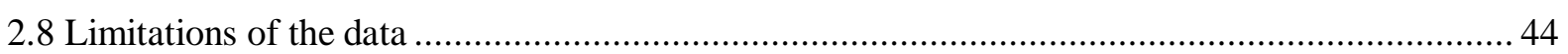

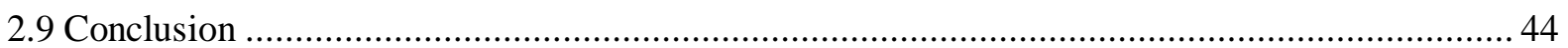

\section{Chapter Three}

\section{Mining: History and current development trends}

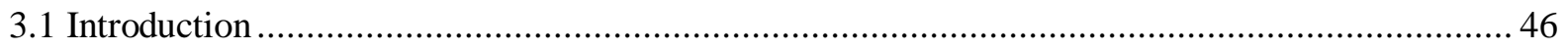

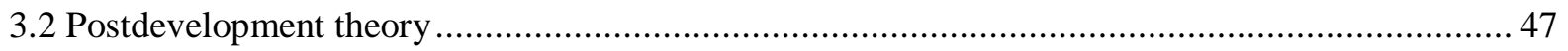

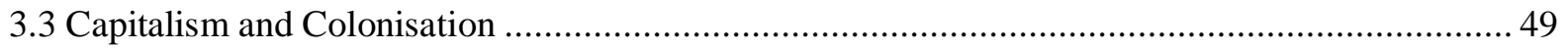

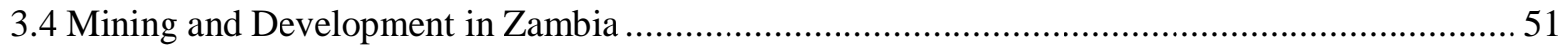

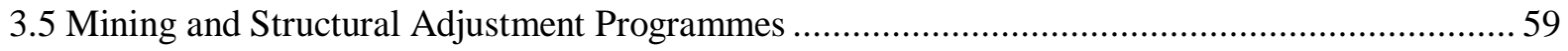

3.6 Current situation in Zambia and macro-economic policies.............................62

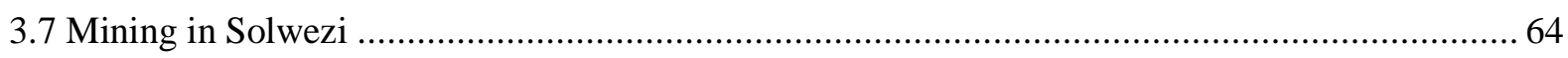




\section{Chapter Four}

\section{Mining, Corporate Social Responsibility and edcuation}

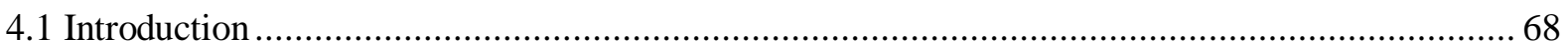

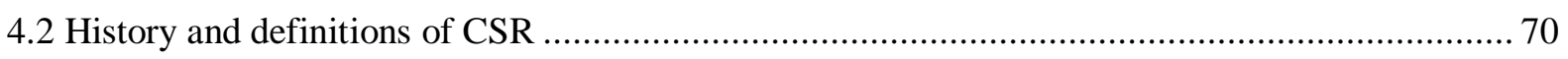

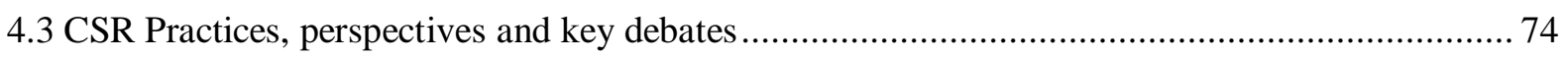

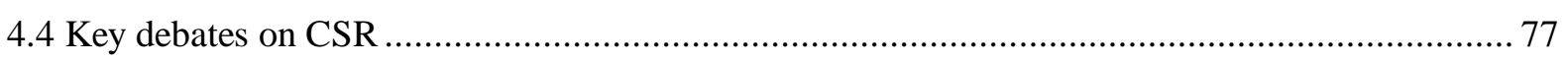

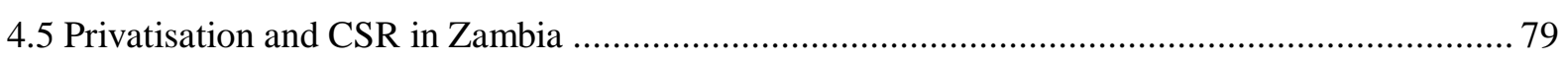

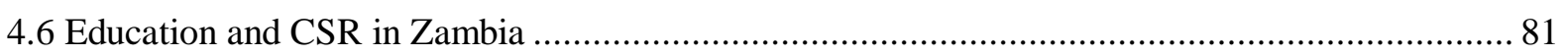

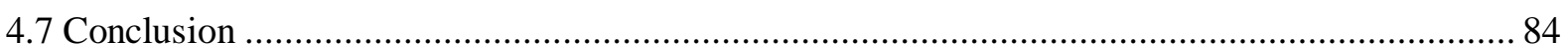

\section{Chapter Five}

\section{Findings and analysis}

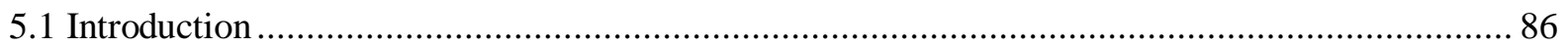

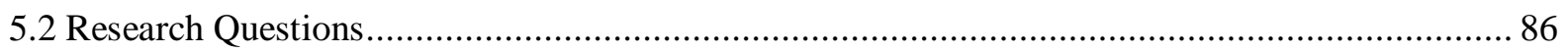

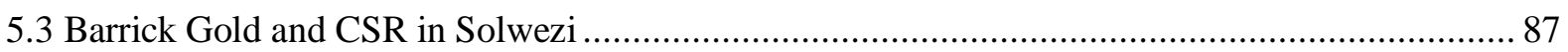

5.4 Barrick Gold's engagement with the Solwezi community and government ............................... 88

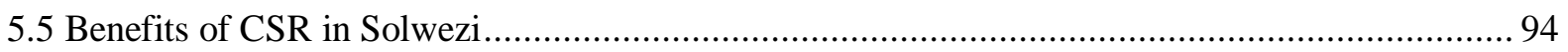

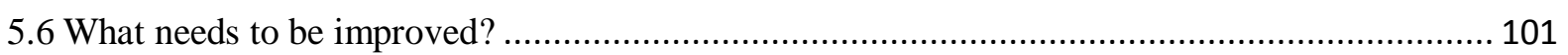

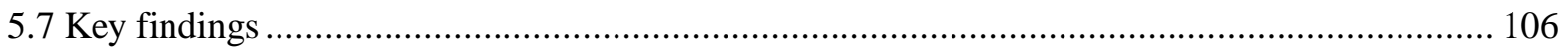

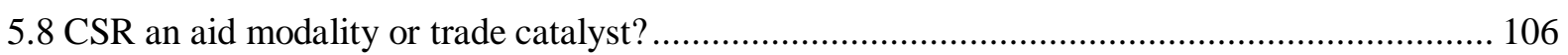

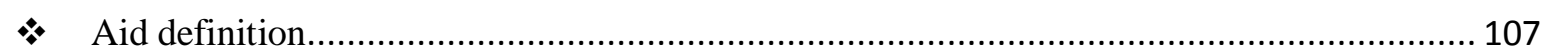

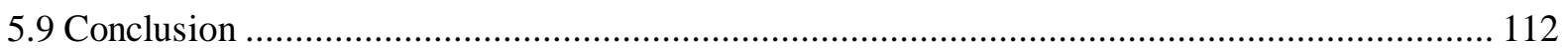

\section{Chapter Six}

\section{Summary and conclusion}

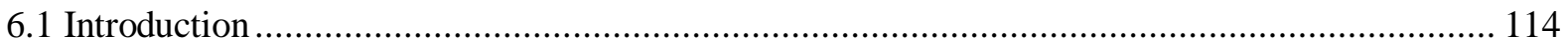

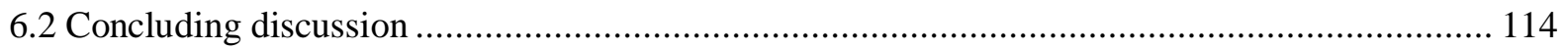

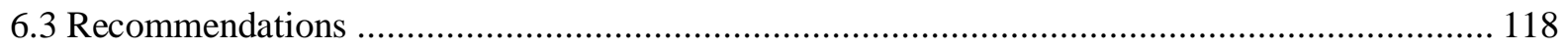

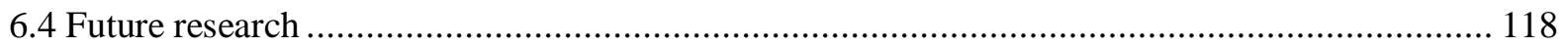

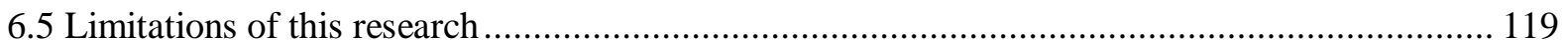

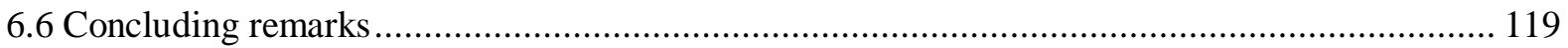

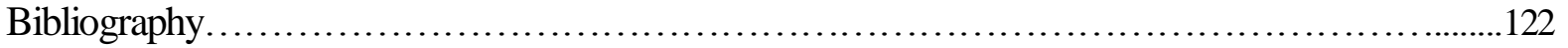

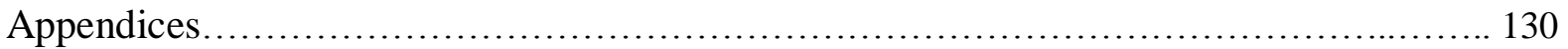




\section{List of Figures}

Figure 1.1 Map of Africa with names of countries

Figure 1.2 Map of Zambian Provinces ...........................................................................................

Figure 1.3 Map of North-western Province of Zambia................................................................18

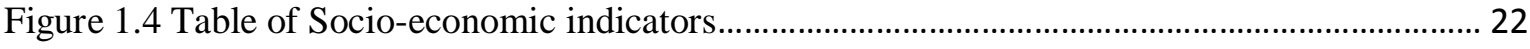

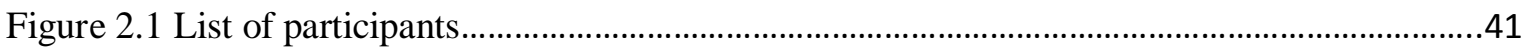

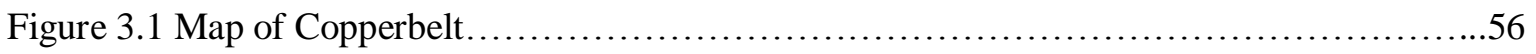

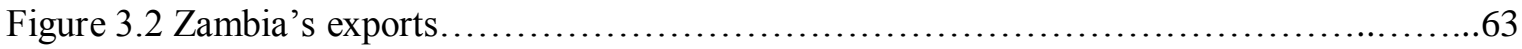

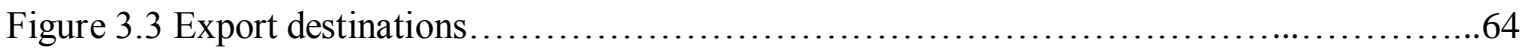

Figure 4.1 Carroll's 1991 pyramid....................................................... 71

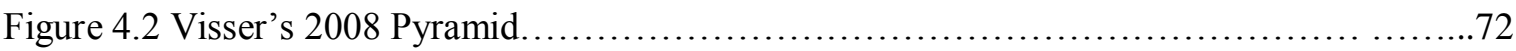

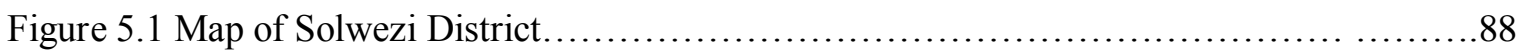

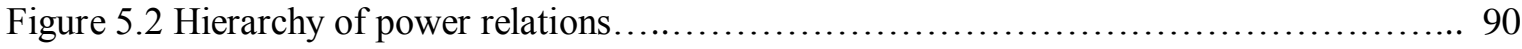

Figure 5.3 Picture teacher's makeshift accommodation.....................................95

Figure 5.4 Picture of newly constructed teacher's house....................................96

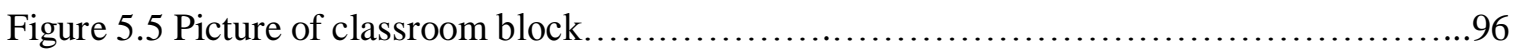

Figure 5.6 List of schools and expenditure.............................................. 97

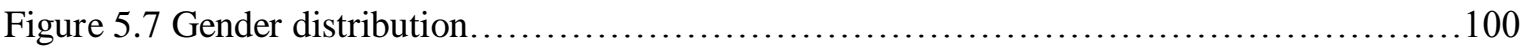




\section{ABSTRACT}

Corporate social responsibility (CSR) has become a widely accepted non-core but essential part of profit making corporations. Practices vary in different companies and different countries. The motivation for each is different but nonetheless there is an agreed unwritten code about being good corporate citizens. CSR has become common place for companies in Zambia. Mining, telecommunications companies, banks and hotels practice CSR initiatives in different forms.

Mining has been the biggest revenue earner for Zambia since the colonial era. Since the 1990s, CSR has been taken on by the mining companies in order to contribute to the community where they are situated. This research explores how CSR is perceived by local people, traditional leaders and district government officials from Ministry of Education in Solwezi. Solwezi is home to two of Zambia's largest mines namely Lumwana and Kansanshi mines owned by Barrick Gold and First Quantum Minerals respectively. These two mines have been established in the recent past in Solwezi and have become the hub of Zambia's economic activity and have been dubbed the 'New Copperbelt'. This thesis will look at Barrick Gold and the education projects that the mining company implements as a case study in CSR.

The literature reveals that mining has been both helpful for economic growth yet detrimental socially and environmentally. There has been a disillusionment among people of the original Copperbelt who experienced cycles of boom when the copper prices and production are high and bust when the copper prices and production were low. In the New Copperbelt, Barrick Gold implements projects such as women's savings, education, health and agriculture. Many of the education and health projects involve infrastructure development. Even though this is the case, this thesis' findings indicate that the community who are the intended beneficiaries of the education projects perceive that more can be done in terms of education programmes over and above what Barrick Gold is currently doing. Accountability and transparency are also issues of concern for the officers at the Ministry of Education. This thesis explores how these interwoven connections work for and against access to education in the community level. 
Overarching themes; Mining, Privatisation, CSR, Postdevelopment, Feminist approaches, development, community. 


\section{ACKNOWLEDGEMENTS}

As this part of my life in which I have pursued this masters' programme comes to a close, I would like to firstly acknowledge the support I have received. This has been no doubt the most challenging and yet fulfilling part of my life.

Firstly I want to acknowledge the mighty hand of the Almighty God, Yaweah the creator of heaven and earth and all mankind through whom I have had the ability to soldier on even during the tough times.

I am highly indebted to my supervisors Dr. Marcela Palomino-Schalscha and Dr. Sara Kindon whose support, feedback, correction and encouragement are highly valued. I can never thank both of them enough for helping me through this journey especially during the time I was writing my thesis. Many times I felt like giving up but their encouragement and interest in my work and wellbeing were a great help for me to see the big picture.

I would also like to thank all the people who participated in the fieldwork. Despite their busy schedules they accorded me the time and patience to speak to me during the face to face interviews and focus group discussion. This whole thesis would not be possible without their thoughtful insights and statements.

I am also grateful to Linda Sutton who allowed me to stay in her house and gave me a sense of family and belonging. I am thankful to all the lovely people I met at the Arise Church in Wellington and who embraced me dearly. David my husband was absolutely amazing and knowing that he was taking care of our children gave me more peace of mind. I am thankful to my parents, my sisters and brothers, my uncles, aunties and cousins who were always sending me encouraging emails and text messages in all the time I was in New Zealand.

Last and not the least my gratitude goes to friends I met in New Zealand, Brenda, Christopher, Rose, Denis, Sofia, Upendo, Sixfred and Zawadi. I also thank all fellow classmates many of whom became close friends and confidants. Thank you for listening, smiling and greeting. I am also thankful to my office mates Cristian Leaman and Lillian Fougère who are very focused and their work ethic motivated me to work hard. 


\section{List of Acronyms}

$\begin{array}{ll}\text { AAC } & \text { Anglo-American Corporation } \\ \text { BCC } & \text { Behaviour Change Communication } \\ \text { BSAC } & \text { British South Africa Company } \\ \text { CSR } & \text { Corporate Social Responsibility } \\ \text { DDCC } & \text { District Development Coordinating Committee } \\ \text { DEBS } & \text { District Education Board Secretary } \\ \text { GDP } & \text { Gross Domestic Product } \\ \text { IGA } & \text { Income Generating Activities } \\ \text { IPO } & \text { Initial Public Offering } \\ \text { LME } & \text { London Metal Exchange } \\ \text { RST } & \text { Roan Selection Trust } \\ \text { SAP } & \text { Structural Adjustment Programme } \\ \text { SWAp } & \text { Sector Wide Approach } \\ \text { ZCCM } & \text { Zambia Consolidated Copper Mines }\end{array}$




\title{
CHAPTER ONE \\ Context of mining and Corporate Social Responsibility in Zambia through a postdevelopment lens and feminist approaches
}

\author{
Zambia Vision 2030
}

\section{Vision statement reads in part}

Zambians, by 2030, aspire to live in a strong and dynamic middle-income industrial nation that provides opportunities for improving the wellbeing of all, embodying values of socioeconomic justice, underpinned by the principles of: (i) gender responsive sustainable development; (ii) democracy; (iii) respect for human rights; (iv) good traditional and family values; (v) positive attitude towards work; (vi) peaceful coexistence and; (vii) private-public partnerships. Mining sector should have well organized private sector led mineral resource exploration and exploitation that contribute to sustainable social economic development by 2030.

Source: Ministry of Finance and National Planning (2006, p.8)

\subsection{Introduction}

Zambia is a landlocked country of about 13 million people in Southern Africa. It has a long history of mining. Mining has been a key if not the most important driver of the country's economy since the 1920s when commercial mining commenced in Zambia. However, the mining industry has contributed to turbulent economic times too. Copper mining is feast or famine in nature because when copper prices and production are high, there is an economic boom but when copper prices and production decrease, the economy suffers. This is the Boom and Bust Theory suggested by Fraser and Larmer (2010). There are a lot of external factors that lead to this situation such as the copper prices on the London Metal Exchange (LME), the nature of Zambia's geography (being a landlocked country), and high production, export and transport costs. Currently the price of copper on the LME is favourable and copper exports account for 74.5 percent of Zambia's total export earnings (Zambia Central Statistical Bulletin, 2013). This results in income from the copper mining industry in Zambia being a significant part of the economy.

As stated in the excerpt of Zambia's Vision 2030 above, public-private partnerships and private sector-led mining exploration and exploitation is part of the vision to becoming a middle income prosperous nation (Ministry of Finance and National Planning, 2006). This vision document is a strategy paper that spells out how the Zambian government intends to 
achieve national development objectives. The Vision 2030 strategy provides a premise for partnership with the private sector in matters of economic as well as social development. Therefore I have undertaken this research to show how one mining company is contributing to the broad development goals of the government through their work in Solwezi district. Furthermore, this thesis looks at education projects implemented by Barrick Gold through their Corporate Social Responsibility (CSR) activities. This research is a contribution to the broader body of knowledge of CSR in the mining sector in Zambia. It also brings perspectives from the intended beneficiaries of CSR projects and the government.

Since the mid-1990s when mines were sold to private investors, they began to practice CSR, which can be defined as companies being socially responsible in order to increase their market share (Cramer, 2006). It is also a way of supporting the community in the area where they operate (Lungu \& Mulenga, 2005; Banks et al, 2013; Gilberthorpe 2013). They engage in projects such as agriculture, women's savings clubs, education and health. There are extensive discussions in the literature review in Chapters Three and Four exploring the role of CSR in community development. Although there is no one common definition of community development, for this research it is considered to be the provision of social services such as education and health facilities as well as economic opportunities. Many companies in Zambia engage in CSR out of a moral obligation to be a 'good' corporate citizen because CSR as a non-core activity of mining companies is not directly related to mining (Fraser 2010). Other motivations include, but are not limited to, public relations, ethical considerations, competition and international pressures. This thesis explores how local people in a community and Ministry of Education officers perceive mining and CSR in education. Because I am a Zambian who is a native of and lived in the North-western province for several years, I am well aware of the possibilities and challenges posed by CSR and therefore I bring my own perceptions, experiences and commitment to search for better alternatives when exploring this issue.

A case study was chosen for the primary research, which was conducted in Solwezi, the area where Barrick Gold a Canadian firm owns Lumwana Copper Mine. I chose this district because Solwezi has two large mines operating in the area and has become the hub of Zambia's economic activity. Although Barrick Gold has embarked on several CSR initiatives in areas such as health, village banking, education and agriculture, this thesis focuses on the education initiatives as a core community issue. Because education is inter-related with other social issues, mention is made of the intersections with the other sectors. The research draws 
on information and perceptions from the local people, the Ministry of Education, teachers, school managers, the chief and staff from Barrick Gold.

This introductory chapter first discusses the context of the case study and the importance for development in this area. Secondly, it explores the wider context of CSR and mining in Zambia. Then it discusses the methodological and philosophical approaches and the research aim and research questions. I end this chapter by giving a detailed outline of the whole thesis and what each chapter contains.

\subsection{Case study context and the need for development}

Solwezi, the chosen case study area, is in the North-western province of Zambia, in Southern Africa, as seen in Figure 1.1 and 1.2. Solwezi is the area also known as the New Copperbelt because two mines have opened in the area since 2005 and 2007, and they are making a significant contribution to the national treasury in terms of revenue. However Uranium ${ }^{1}$ one of the Chiefs in Solwezi stated that "the mines in Solwezi are contributing 65 percent to the national treasury, but this is not equitably distributed" (Interview $6^{\text {th }}$ May 2013). Solwezi used to be a predominantly agrarian district with few commercial activities. There were subsistence farms growing beans, sweet potatoes and Irish potatoes, and small scale fishing. The district is still known for the production of brown beans called Solwezi Beans, and 'Chingovwa,' the local name for the variety of sweet potato (Kumara) grown in this area. Kaonde is the main tribe in Solwezi originated from the Congo basin a cultural heritage of fishing and agriculture. The opening of the Kansanshi mine owned by First Quantum Minerals, a Canadian firm in 2005 and the Lumwana mine in 2007 have brought significant changes to the landscape and culture of the district.

\footnotetext{
${ }^{1}$ To maintain the confidentiality of participants' identities, pseudonyms have been used in this thesis using mineral names.
} 


\section{Figure 1.1}

Map of Africa with names of countries

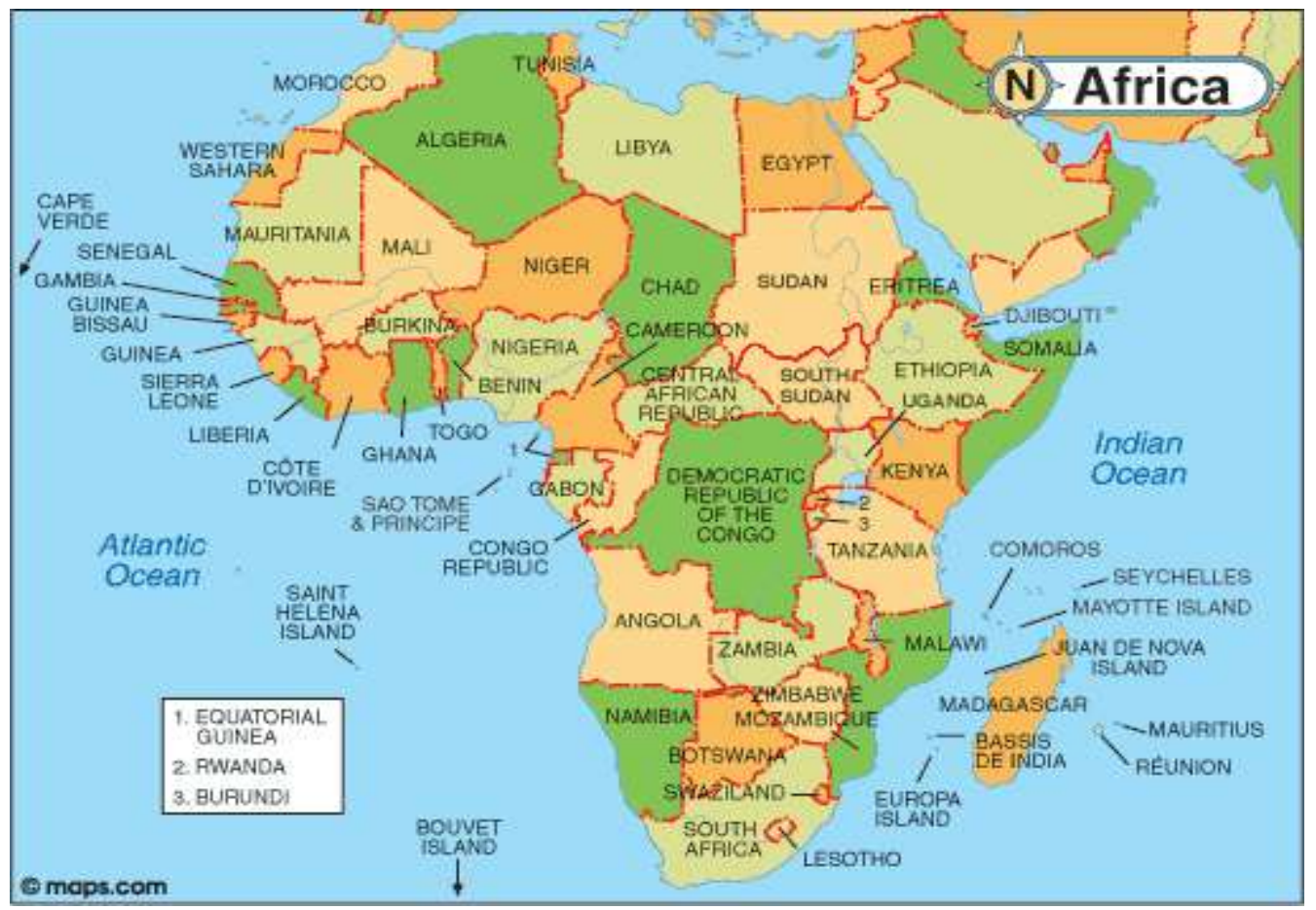

Source: http://www.infoplease.com/atlas/africa.html

\section{Figure 1.2}

Map of Zambia showing provinces and provincial capitals

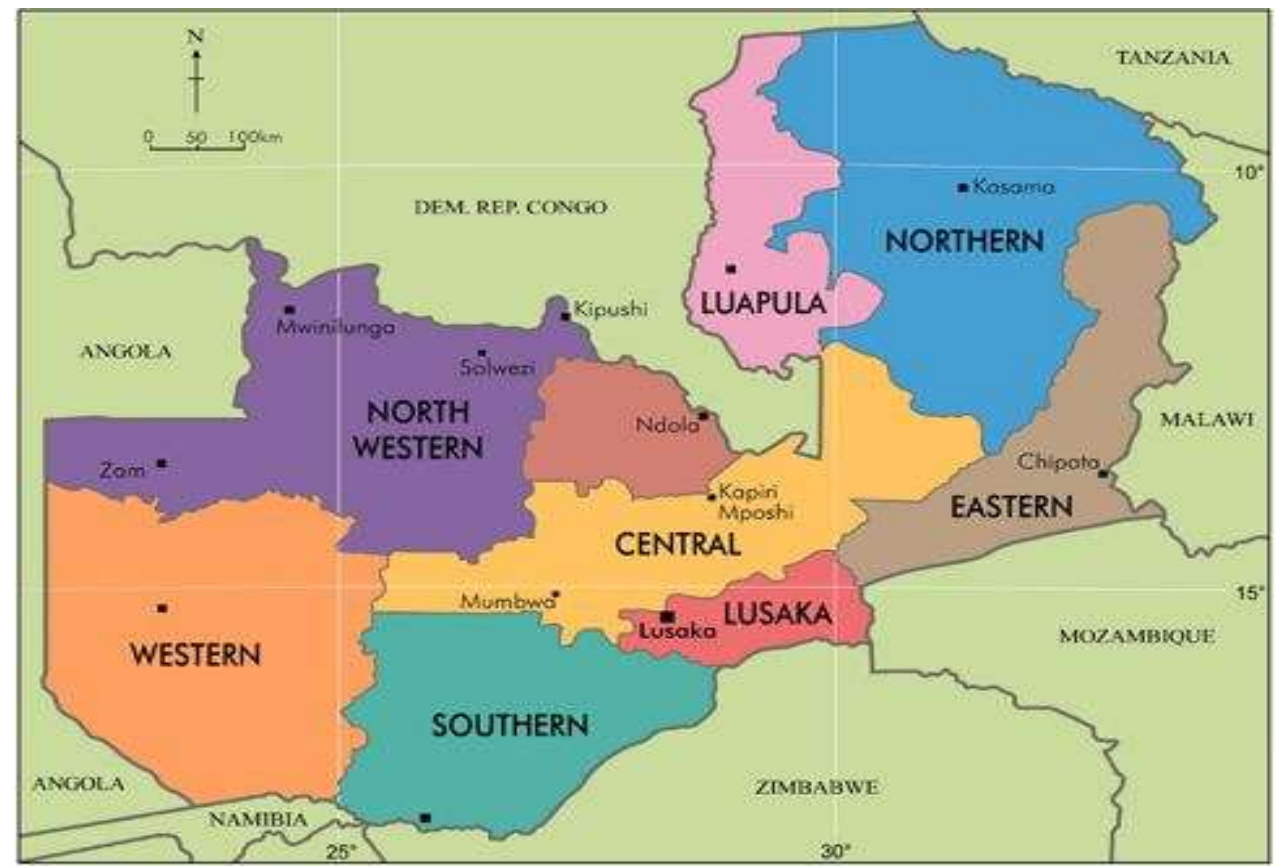

Source: Mapsof.net (2013) 


\section{Figure 1.3}

Map of North-western Province of Zambia

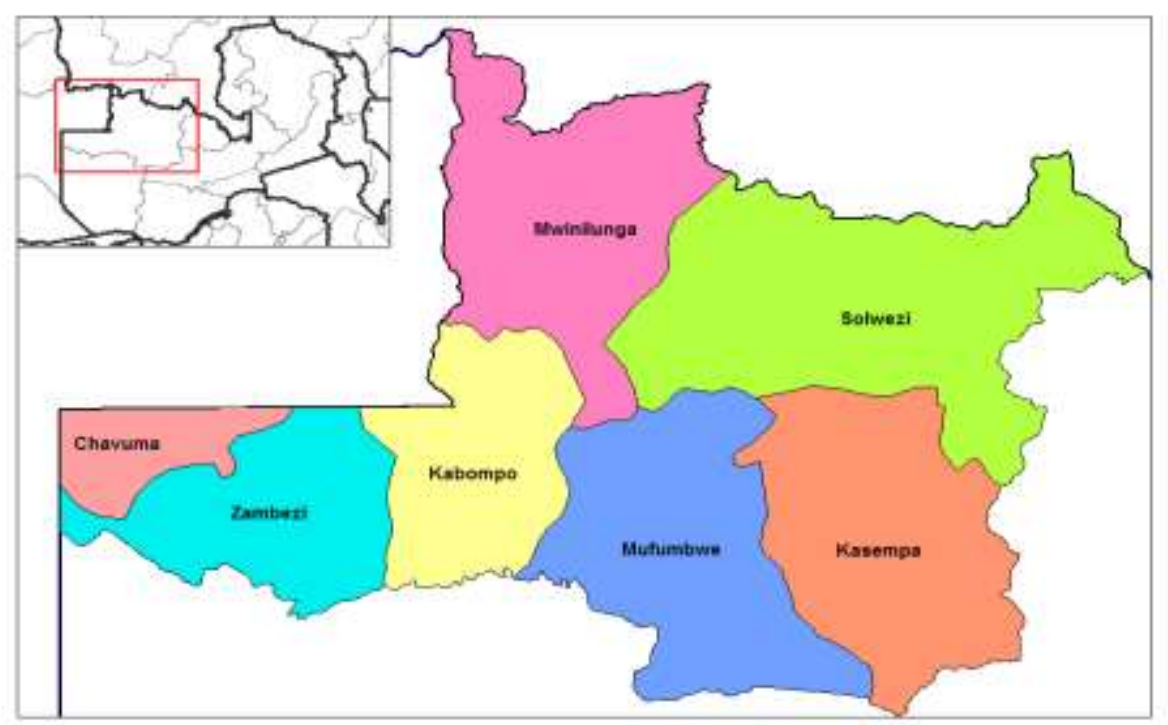

Source: Mapsof.net (2013)

Solwezi is the provincial capital of the North-western province with a total population of 706,462 people. Solwezi has an active local government divided into several ministries such as education, health, agriculture and there is a district council among others. Solwezi is approximately 600 kilometres from Lusaka, Zambia's capital city. The case study research focused on education projects being implemented by Barrick Gold through their CSR framework. Barrick Gold implements many different kinds of projects in the Solwezi district, and the case study focuses on the education project, owing to its importance to the local people. Figure 1.2 above shows the provinces, Solwezi is on the Eastern side of Northwestern province and that is what constitutes the New Copperbelt.

My first encounter with stark poverty in Zambia was in the North-western province in 2003 when I took up a job with World Vision, a humanitarian and development organisation. I was confronted with children who had all kinds of conditions such as malnutrition, scabies, jiggers and diarrhoea. This was in a small town called Mwinilunga, which is near the Zambia-Angola border see Figure 1.3. At that point it became more than just a job and I knew I wanted to help in any way I could to alleviate the poverty of these people. Despite Zambia being resource rich in copper, poverty remains endemic, especially in rural areas. My 
paternal village is in the North-western province west of Solwezi. For the people of Solwezi, their dilemma is very vivid because even though their land is endowed with minerals, trees and rivers, they grapple with inadequate social services such as schools, medical clinics, teachers' accommodation and money to pay for children's school fees. These are the reasons that motivated me to pursue a Masters' development studies and to choose Solwezi as the case study for this thesis.

The need for education cannot be ignored because the local people of the area and those coming from other cities all compete for jobs and business opportunities associated with the mine. Livelihoods have changed and people are not engaging in small scale farming as much as they used to before the mines were opened. Maconachie and Hilson (2013) state that traditional livelihood structures are destroyed by the pursuit of mineral wealth which can, in turn, cause further changes in agrarian livelihoods by negatively altering natural resources such as land and water. This is what happened in the original Copperbelt province (Fraser \& Mulenga, 2006). It is likely that if precautions are not taken the same could happen in the New Copperbelt (Solwezi). Agriculture production and fishing have slowly reduced in this area. Apart from education being a contributor to economic growth through provision and upgrading of human capital, it is also one way in which the people of Solwezi can gain economic and other benefits such as empowerment and skills to work in management and technical positions in the mine. Mandela (1995) explains this clearly when he states:

Education is a great engine of personal development. It is through education that the daughter of a peasant can become a doctor, that the son of a mine worker can become the head of a mine, that a child of a farm worker can become the president of a nation (p. 194).

Mining companies require minimum qualifications for someone to be considered for employment. They require a full high school completion certificate even for unskilled labour. For other administrative or technical level jobs, tertiary education is required.

The employment situation is compounded by rigid trading requirements that hinder growth of the informal sector. For a local company to trade with the mine as a supplier or contractor, certificates of incorporation, tax registration and other statutory requirements are necessary in order to be considered as a business partner. These conditions are often out of reach for local small-scale businesses. As such, businesses from other cities have established themselves in Solwezi to fulfil the domicile requirement, excluding the local businesses from economic 
benefit. Education is not only the second Millennium Development Goal (United Nations, 2013), but it is a means (probably not the only one, but important) by which people of Solwezi district can prosper, whether they aspire to work in the mine or do business. Potter et al (2008) also give currency to the importance of education when they argue that education and freedom of expression should be key elements in the development process.

The people of Solwezi have a strong attachment to nurture their land, rivers and trees. Chiefs in Zambia are custodians of traditional land. This is land which is not within the vicinity of the central business district of any town or city. Negi (2010) explains that chieftaincy in Zambia has been in existence since pre-colonial times, but became more pronounced during the colonial era because the colonial administration needed someone to carry out their orders. Since the chiefs were, and still are revered, the mining company saw it fit to make them their allies (Negi, 2010). This is akin to many other indigenous communities in Latin America such as Suriname where mining is equally important (Haalboom, 2012). CSR is one way in which the host community can gain economic and other benefits from their land, even though the mines are owned by private companies who negotiate and obtain mining licenses from the central government. The chiefs usually welcome this investment, albeit under duress, because there is still a big gap between the traditional and statutory land ownership, but according to Zambian law, the subsurface minerals belong to the government.

\subsection{Corporate Social Responsibility}

Corporate Social Responsibility (CSR) is a highly contested concept with varied meanings depending on the country, and the political and economic issues surrounding the country. Cramer (2006) suggests that interpretation of CSR depends on the political culture of a certain country. The discourse around CSR has hinged largely on how corporations engage the people in the host community and country where their organisations operate. The issue of corporations and their involvement in the community may look different in different countries. For example in developing countries like Zambia the outlook of corporations is more philanthropic and social in nature. Philanthropy plays no role in China with regards to CSR, as good food supplies and a place to sleep are more pertinent for Chinese employees who are usually employed for a short period of time and live nomadic lives (Cramer 2006). ABN AMRO bank, which has branches in 58 countries, focuses on micro financing and reduction of the company's carbon emission by efficient energy use in Brazil and India, while 
the headquarters in the Netherlands concentrate on being a good employer and creating education opportunities for growth and diversity for employers (Cramer 2006).

Alongside the differences of CSR in different countries and contexts, CSR can be a platform for integrating economic and social policy and practice. De Haan (2007) suggests that it is necessary to integrate economic and social policy so that economic development can directly link to social sectors such as health and education. Mining is the largest industry in Zambia and it accounts for 68 percent of the country's total export earnings (Zambia Central Statistical Office Bulletin, 2013). It is therefore imperative to explore how economic and social policy can be integrated for the benefit of the people in the host community.

In Zambia, CSR is characterised by community development projects and this may not be the case in other countries. Haalboom (2012) states that the community development approach to CSR rests on corporate contributions to community development projects. This can include road building, provision of electricity infrastructure, schools, job opportunities and microcredit lending schemes. Other issues that can be addressed by CSR include indigenous people's rights, human rights in general, environmental and social impacts of the company, workers' health and safety and humane wages (Haalboom 2012). In this broad scope, this thesis concentrates specifically on how Barrick Gold implements CSR in Zambia using the community development approach. It highlights the education projects of Barrick Gold, owing to the fact that globally education is seen as a means by which local people can gain access to employment in the mine.

The employment and school enrolment rate are low in comparison to many other African countries. I cannot provide empirical evidence of the relationship between education and formal employment, but I would like to claim that low employment levels are a result of low education levels among other factors. Poverty levels are high especially in rural areas such as the place where the case study was undertaken. Therefore these indicators are an illustration for the need for more education in particular and other poverty alleviation strategies in general. It is my view that partnership with the private sector mining being a major player in the private sector is essential. Figure 1.4 below illustrates social indicators in Zambia. This is necessary in order to understand Zambia's socio-economic landscape. In particular it illustrates the need for more investment in social development programmes in Zambia. 


\section{Figure 1.4}

Table of socio-economic indicators for Solwezi and Zambia

\begin{tabular}{|l|l|}
\hline Solwezi Population & 706,462 \\
\hline Zambia rank in HDI & 163 \\
\hline Zambia Population & $13.4 \mathrm{~m}$ \\
\hline Zambia GNI per capita & 1,254 \\
\hline Zambia GDP per capita & 1,430 \\
\hline Zambia Net enrolment rate (primary \& secondary) & $47 \%$ \\
\hline Employment Rate & $19 \%$ \\
\hline Population on \$1.25/day & $64 \%$ \\
\hline Mining export revenue & $74.5 \%$ \\
\hline Mining contribution to GDP & $70 \%$ \\
\hline
\end{tabular}

Source: Bank of Zambia Report, Zambia Central Statistics Office and Human Development Report (2013).

\subsection{Mining in Zambia}

The mining industry is Zambia's most lucrative revenue earner. There has been a lot of rhetoric on diversification but this has not happened. Rising global copper prices stimulated the opening of the first mine in Zambia in 1928. This was a mine jointly owned by the Roan Selection Trust (RST) and the Anglo-American Corporation (AAC), (Fraser 2010; Lungu 2008; Mususa 2012). Cecil Rhodes, a South African businessman of British descent, was the key protagonist and he had a large stake in RST. This was during the colonial era and Africans worked in the unskilled sector, or underground drilling, while the Europeans, and later, Asians, worked in the more technical areas.

During the first decade of copper being discovered and commercial mining commencing in Zambia in 1928, urbanisation grew as people moved to the Copperbelt province of Zambia in search of employment in the mines and Zambia was urbanizing at a very fast pace (Ferguson 1999). Although there was growth for about six years following the establishment of commercial mining, turbulent times soon came and much of the gains made socially, economically and otherwise, plunged. Fraser (2010) recounts that in 1929 the Great Depression hit and the workforce of mostly men who came from rural areas to work in the mines shrunk from 30,000 in 1928 to 7,500 in 1932. During that period copper prices and 
production declined (Lungu, 2008). Zambia was a British colony since 1898, (Lambert, N.D.) and therefore much of the macro-economic fiscal policy was directed from Britain. In 1964 Zambia gained independence and Kenneth Kaunda became the first President of Zambia.

In the late 1960s, the copper prices and production had improved but there was still dissatisfaction among the workers. Fraser (2010) states that the newly elected government saw this as an opportunity to cash in on their popularity and they implemented the Nationalisation Policy. Mines were bought from the RST and the AAC and government controlled the major stake (Fraser, 2010; Lungu, 2008). After the nationalisation process, the mines took on several social services as part of their responsibility in order to appease the workers who by this time were part of powerful trade unions. But turbulent times returned during the oil crisis of 1979/1980 (Auty, 1993). The copper prices on the London Metal Exchange (LME) fell, along with production, and the debt burden increased and the Zambian economy took a steep decline once again (Ferguson 1999; Fraser, 2010; Lungu 2006). Eventually by 1991 a new government was ushered into office after a dramatic election in which President Fredrick Chiluba won a landslide victory because Zambians wanted a change of government. President Kaunda had previously ruled for 26 years and he declared a one party state. With the new political dispensation came new policies, the most prominent being Structural Adjustment Programmes (SAPs) and the privatisation of many government operations. Currently the mines are owned by private transnational corporations (TNCs).

The welfare approach to mining with regards to treatment of workers and local people in the mining areas has not been consistent during the period that the new owners bought and took over the mines. Gewald and Soeters (2010) state that the new foreign investors have shown significantly less interest in taking responsibility for non-core business services which Zambia Consolidated Copper Mines (ZCCM) had provided to the people. This is one of the main reasons for undertaking this study - to explore this situation. It is worth noting that even though the social well-being of the Zambian populace was unimportant during the privatisation negotiations, the government is still unable to meet all the social service requirements. Owing to this gap, I believe CSR initiatives have the potential to become the social welfare service that ZCCM used to provide at least for the rural population where the new mines have recently been established. 


\subsection{Theoretical and Philosophical Approach}

This research is situated in the broader context of postdevelopment theory, which questions development policy and practice and seeks to challenge the status quo of what development purports to do. The integral question hinges on the fact that aid and development practice in its current format has not yielded desirable results, at least not for the under-developed countries in the Global South. This thesis focuses on evaluating the mining sector in Zambia as a means to development. The discussion in this thesis looks at the challenges and opportunities of the mining sector in Zambia to contribute to development through different economic and political phases and also discusses perceptions of CSR from various stakeholders.

In this research, CSR from copper mining in Zambia is analysed using the theoretical lens of postdevelopment. Even though CSR is not classified as an aid modality in the traditional sense, in this thesis it is considered as external financial support for rural communities akin to aid modalities. Postdevelopment is a theory that researchers, academia and development practitioners have been championing and it has gained considerable ground, especially among scholars and practitioners in Latin America and sub-Saharan Africa. The theory revolves around a critical analysis of development and poverty, and how they have been constructed by the West. Escobar (1995) argues that the classification of two-thirds of the world as poor because they lacked material possessions and money created a problematisation of poverty and the developmentalisation of the Third World as a solution. The label was created and Africa, Asia and Latin America were classified as poor. Most importantly the solution to such poverty was prescribed in economic development terms by the West.

Africa is classified as Third World and poor owing to the per capita measurement created by World Bank. Escobar (1995) also argues that vernacular societies in Asia, Africa and Latin America developed ways of defining and treating poverty that included communality, frugality and sufficiency, but these were broken down when market forces took precedence and millions were deprived of water, land and other resources. This thesis follows the notion that there are alternatives ways in which development is defined and practised, and that there is the need to seek multiple trajectories apart from the prescribed modernity.

The imposition of terminologies such as 'Third World' 'Poor Countries' and 'Least Developed' by the West compels me to think about the need to join the proponents of postdevelopment in rethinking these terminologies and deconstructing the binaries created. It 
is important to think about who defines poverty and who prescribes solutions. These are tough questions even for me as a development practitioner who is thinking about the rural people who need schools so that their children can be educated and get jobs in the mine. As Robert Chambers (1989) would ask: What if they are content with agrarian and fishing lifestyles? Whose development is it anyway?

The choice of postdevelopment as a theoretical framework and use of feminist approaches in this thesis is not lightly chosen. The theoretical and philosophical approaches intersect in that they both question the power relations and Western hegemony over the rest of the world. McEwan (2001) argues that for the Third World black woman no one single source of oppression exists but gender oppression is inextricably bound up with race and class. Feminist approaches will not only allow me to question issues of race but gender and class as well. Postdevelopment lens and feminist approaches are the theoretic and philosophical lenses through which this research is conducted and the knowledge is produced and interpreted. I am motivated by seeking alternatives, challenging the status quo and exploring a better way of undertaking community development that can be practised by corporations. I am interested in bringing the voices of the people in the community where this development is taking place to the forefront. A postdevelopment and feminist approaches privileges that voices of people often not heard.

\subsection{The research problem and questions that directed this inquiry}

The North-western province is plagued by several socio-economic malaises. For the past several years, the province was ranked among the poorest provinces in Zambia. The situation has improved with the opening up of two large-scale mines and exploration for other mines and oil in other parts of the province. In terms of social services, the province has lagged behind in terms of access to education, health and farming inputs. Poverty remains a harsh reality for many people of the North-western province. It is for the reason stated above that CSR can be perceived as an alternative source of income for provision of social services so that the corporations operating in the area can offer benefits to the local people to whatever extent possible.

The research and literature in CSR focuses on what companies are doing to alleviate the poverty of the communities or countries within which they work. There is little information from the perspective of the local people who receive this support. From my literature review, 
I have observed that there has been very little research on CSR and its benefits within Zambia. While the community does not have control over the amount of money CSR provides, they can at least be part of the process and contribute their views and aspirations on how to implement CSR. In my view, this participation may lead to optimal community benefits from the CSR activities.

Solwezi, the case study area, has few schools and low literacy levels. This inhibits the local people from accessing skilled employment in the Barrick Gold mine. Many employees come from abroad and from other towns. I chose to conduct my field work in Solwezi because two mines have recently opened there and they each have a projected lifespan of more than 30 years. Given that these mines are so new, there is an opportunity for this research to influence the way that CSR is planned and implemented in the local community. The mines are a potential source of funding for social programmes such as education and health.

The overarching research aim of this thesis is to explore how local people in the community and the Ministry of Education officers perceive the mining and CSR projects implemented by Barrick Gold. Community is used to describe people in Solwezi district in general and particularly those from Lumwana area where the mine is situated.

The research questions are:

1. What is the history and current practice of mining in Zambia's development?

2. What is the history, current debate and practice in CSR globally and in Zambia?

3. How do people in Solwezi community perceive Barrick Gold's CSR education programmes in terms of benefits and shortfalls?

4. How do officers from the Ministry of Education at district level view Barrick Gold's work in the education sector?

5. Can CSR become a form of aid modality for development programmes?

\subsection{Thesis outline}

This thesis is divided into six chapters. This introductory chapter briefly presents the topic and rationale of the thesis and gives a synopsis and outline.

Chapter Two focuses on the research methodology, with the theoretical and philosophical approaches to this research. It includes the philosophical approach and data collection 
methods, choice of participants, justification, reflection on my positionality, and some discussion of the limitations in data collection. It also discusses the challenges of the research and ethical considerations. I have taken a feminist approach to this research, with postdevelopment as a theoretical lens through which knowledge is interpreted.

Chapters Three and Four present the theoretical basis of this thesis. In Chapter Three, literature on mining is reviewed forming a backdrop for the whole research. The theoretical framework of postdevelopment and its intersections with colonisation are also discussed in this chapter. The description of the history of mining at a global and national level gives further context. It also explains mining and development in Zambia from the preindependence era until now. This chapter responds to research question one above.

Chapter Four reviews literature about CSR and the history of how it has evolved. This is discussed globally as well as specifically in the Zambian context. Chapter Four also highlights national socio-economic indicators and discusses how important CSR is in terms of providing additional funding for social amenities to benefit the host community. This chapter responds to research question two.

Chapter Five discusses the research findings and how the community, traditional leaders and Ministry of Education officers perceive CSR, mining and education in Solwezi. This chapter gives detailed accounts of information as given by participants as well as my analysis and interpretation of their accounts. I also demonstrate that despite what is being achieved through CSR, members of the community and Ministry of Education would like more from CSR. The information in this chapter answers research questions three and four by presenting the participants' perspectives and thoughts and analyzing this in light of the literature.

Chapter five also discusses the possibility of CSR being considered as an aid modality to fund a sector-wide approach (SWAp) or project funding. Exploring the manner in which CSR is implemented and how funding is disbursed, the following questions are asked. Does it conform to the Paris Declaration? What are the similarities or differences? The chapter discusses the challenges and opportunities of the CSR model in the provision of social services. It also discusses the current education policy and the current funding mechanisms with regards to service delivery. Based on the premise that there is no policy framework within the Zambian government to govern implementation of CSR by corporate institutions by the Zambian Government, they do as they see fit. This section responds to research question five. 
Chapter Six is the conclusion of the whole thesis. It highlights future prospects of CSR in Zambia. I endeavour to bring all that has been discussed and drawing on main issues identified, link them to broader debates in development studies. As I speak back to postdevelopment theory, I highlight the complexities of CSR as a means of community development. I also demonstrate that no simplistic solutions or prescriptions can create meaningful change but change will take forethought, stakeholder participation and careful planning to make a tangible contribution in people's livelihoods. 


\section{CHAPTER TWO \\ Epistemology, Research Design and Methodology}

\subsection{Introduction}

The previous chapter explained the place, context and scope of this thesis. It highlighted the key themes of this thesis and gave an overview of the chapters. This chapter will move on to explain the epistemology and methodology of the whole research both in theory and as it was practiced during and after the field work. This thesis aims to examine how CSR in the mining sector is practiced and the benefits it is rendering to the community. It is situated in the broad context of postdevelopment theory as a theoretical framework and feminist approaches as an epistemological basis. The philosophical, theoretical and methodological views have been chosen partly because of my world view and my intention to question the status quo of Western hegemony as it relates to development whether at community or national level. I seek to question the power imbalances that occur with CSR as an aid modality. To do this, I have chosen a methodology and case study that will allow an exploration of the perspectives from the people of Solwezi and Ministry of Education with regards to CSR. From this exploration I will draw my conclusions regarding how CSR is, or can be, an effective tool for development in this specific context.

This chapter outlines the methodology that was used in this research. It gives details of the epistemology, my positionality as a researcher, the research methods used for data collection, data analysis, ethical considerations, limitations of the research and challenges. Each of these aspects of the research design and methodology will be explained in detail. The research design and methodology is the foundation upon which the data collection process is built. Because research methodology is of great importance, my epistemology and positionality guided the selection of data collection methods, analysis and the choice of participants.

\subsection{Epistemology}

Epistemology is the philosophical approach of the researcher. How does the researcher know what they know? What worldview underpins the researcher's way of knowing and interaction with people and information that he or she derives from research participants? Below I explain my epistemology. In this thesis instead of looking at myself as a detached observer and as an omnipotent expert (England 1994), I approach this research as a partially interested 
candidate who is constantly reflecting on issues and seeking answers. I have taken advice from Palomino-Schalscha (2011) who states that approaches and the methodology taken for any study should be politically, historically and culturally appropriate for the peculiarities of the topic being researched. I have therefore chosen methods that conform both to the peculiarities of the people in Solwezi district as well as my own motivation, positionality and aspirations.

\section{Feminist Approaches}

Feminist approaches influenced how data was collected and analysed. It has influenced how the research findings were interpreted and how knowledge will be generated in this thesis.

Feminist approaches point out the ways in which institution and practices both differentiate the sexes and also make them unequal. Feminist scholars have taken up the necessary and overdue project of challenging the racial-ethnic differences among women, breaking down the problematic feminist view of womanhood as a universal category and women's oppression as a common and shared experience. Raceethnicity, gender or class differences/discrimination cannot be understood if isolated and viewed as separate from each other because they have been experienced simultaneously. (Amott \& Mattaei 1996, p. 5)

The research is influenced by feminist approaches which not only gives a critical perspective on gender alone, but race and class as well in cognizance of Amott and Mattaei's explanation above. I would like to state that this is not just an issue of gender equality, but rather of questioning male dominance, Western hegemony and power relations in various forms and at various levels. Phillips (2005) describes feminism as the politicisation of epistemology which emerged in the 1970s as a radical and critical social movement seeking to change things and not simply study them. Feminist approaches also suggest that science and commerce reflect the position of, and are dominated by wealthy Western men (Kitchin \& Tate 2000). Kitchin and Tate suggest that there is a preeminent existence of men in general creating situations where women are subservient to men, in both the public and private sphere. It is this male dominance and power imbalance that feminism seeks to confront and address. The power imbalance can appear in various forms such as gender, racial and the West-Rest inequalities. 
Feminist approaches therefore, are not restricted to issues of gender alone. Feminism's emphasis on the different power imbalances led me to recognize the need to renegotiate the role and structure of institutions in the production of knowledge. This is a subjectiveobjective reality with constructions resulting from different systems of representation. I sought to understand the systems, structures, policies and practices that underpin the implementation of CSR projects with a focus on power relations. Kitchin and Tate 2000 state "Feminism is a political project seeking empowering and emancipatory benefits for the research participants," (p. 18). This gives currency to feminist approaches in that they are derived from feminism as a wider philosophical and political construction. Visvanathan et al (1997) state that the first project of the feminist approach is to deconstruct and dismantle, while the second is to build and construct. They further argue that unless these processes, though seemingly contradictory, take place simultaneously "Third World" feminists risk being marginalized from mainstream and Western development discourses.

This position is supported by England (1994) who argues that feminist approaches have opened up geography to voices other than white Western, middle-class, heterosexual men. This gives currency to the argument made by Kitchin and Tate (ibid) that feminism is a political project seeking empowering and emancipatory benefits for research participants. Furthermore, feminist approaches provide a more comprehensive project of remoulding a conceptual framework capable of embracing a global politics of social justice (Schech \& Haggis 2000). This is in line with postdevelopment theory in that they both question the power structures whether political, economic, gender or racial. The most prominent issue is Western hegemony. In my view, feminist approaches and postdevelopment share the same principle on how a Western construction of poverty and its prescription of solutions have not been able to yield intended results.

With this epistemological backdrop, I seek to ascertain what makes things happen from the perspective of the people who live the everyday experience in the area being researched. This was in line with my research because I want to investigate the mode of communication between the Zambian Ministry of Education, teachers, the community/parents and Barrick Gold. I want to understand the policy, practice, systems and structures that are part of the world of the people in Solwezi. I am also seeking to explore the various power relations between men and women and boys and girls. I am also interested in exploring what actions produce change and what makes these actions happen in the first place. I am also investigating the extent to which the views of the community, the school and the Ministry of 
Education inform and influence the decision making process of Barrick Gold in CSR implementation. This is in line with England's (1994) argument that feminist approaches in research allows others to speak. This is also in tandem with questioning Western countries' hegemony over countries in the global South. Feminist approaches encourage a renegotiation of power relations in society. In other words, what are the power dynamics between the mining company and the community, between the community and the schools and between the school, the mining company and Ministry of Education? The critical perspectives of feminist approaches are closely linked to the postdevelopment debate because they both question the status quo and suggest alternatives of how development can be funded and practiced differently.

\subsection{My positionality in this research}

Feminist geography has played a major role in challenging the status quo. Phillips (2005) states that feminist geography, among other things i) critiques objectivism and highlighting of the situatedness of theory; ii) the promotion of heightened reflexivity on methodology and iii) challenging the value of major theoretical dualisms such as culture/nature, work/home and public/private. It is imperative to think of one's positionality when conducting research from a feminist perspective. This forms the basis for what data is collected and how it is collected, analysed and interpreted. Harding (cited by Johnston et al 2000) states, "declaring the position from which one writes may lead to more sound analyses rooted in authority of experience than disinterested research which fails to acknowledge partiality" (p. 604). Therefore, I state my position and the standpoint from which I undertook the fieldwork and from which I am doing the research as a whole.

I believe I should start by stating the motivation and reasons for doing this research or a Masters' degree in the first place (Palomino-Schlascha 2011). Firstly, I am motivated by the fact that I am a native of the North-western province of Zambia and my paternal origins are in this part of Zambia. I am a Lunda by tribe which is also one of the tribes that came from the Congo Basin together with the Kaonde people of Solwezi. The Lundas settled in Mwinilunga, north of Solwezi and Zambezi east of Solwezi. Our tribes share a rich cultural heritage and identity. Secondly, I worked in Mwinilunga as a project worker with World Vision. Thirdly, I am a patriotic Zambian who believes that my country is rich in natural resources and I remain committed to contributing towards searching for better alternatives to alleviate poverty and improve the wellbeing of the people in North-western province and 
beyond. Thirdly this area, the New Copperbelt is currently contributing a lot to the economy through taxes and royalties to the Zambian economy (Fraser and Larmer, 2010) and I am curious to see how much of this is benefitting the community directly.

As a Masters' student from the global South (sub-Saharan Africa), a Black African woman with reservations of the West's history and mandate in Africa, I am strongly compelled by my values and disposition. Feminist approaches and postdevelopment theories, discourses and debates have influenced my thinking and perception of investors from the global North. What power struggles exist? What needs to be renegotiated? These and other questions were in the back of my mind before, during and after my fieldwork. I still have the same questions lingering in my mind. I must state from the outset that I am a subjective researcher because I have not completely divorced my personal opinions and characteristics from this research (Hay, 2010). I acknowledge rather than deny my social position, and I reflexively think about who I am and how this can influence this research.

England (1994) states that feminist approaches seek to dismantle smokescreens of neopositivist research which supports the notion that the researcher is an omnipotent expert in control of both research subjects and the research process. I am therefore not a neutral or detached researcher but am partial to questioning power systems and taking a critical look at the status quo. Throughout this whole research process including at the time of writing this thesis I am constantly reflecting on how my partiality, biography and philosophical approach will influence the information I gathered and how I interpret it. With this reflexivity at the back of my mind I am well aware of the need to strike a balance between being personal and subjective. I am fully aware that this is no easy task.

Through the feminist lens I am predisposed to thinking my place is not just in the domestic domain to attend to childbearing and homemaking duties. I am a mother of two young children and a wife, therefore this is a major component of my life but it is not the only important aspect for me. Haggis and Schech (2000) describe the contemporary women as free-born and independent, unconstrained by the bounds of domesticity, respected and helpmates in male endeavours. This is how I see myself and I am truly grateful that David (my husband) is not a typical traditional man who stifles my abilities and professional ambitions. Outside the confines of home I am a professional woman who has spent over 10 years working in the male dominated INGO sector. It was actually because of my ambition to assume a more senior role that I left employment to pursue fulltime study. For this reason, 
this is more than an academic exercise for me because the stakes are high in terms of getting a Masters' degree. I actually agree with Smith (1999, cited in Palomino-Schalscha 2012), who states that although research can be seen as a small technical aspect of wider politics of indigenous people, it can help generate or make more credible and visible knowledge and perspectives to support their priorities and rights. I am hoping to contribute to knowledge on the perspectives of the people of Solwezi and how they view the contribution of the mine in their area to their personal and community lives.

The debate of positionality has been advanced most rigorously within feminist approaches rejecting the hegemony of the "abstract masculunism" and challenging its epistemological claim of universality (Johnston et al 2000 p. 604). With this explanation in mind, I am also interested in questioning male dominance in the work place and in corporate institutions, government departments and the communities in Zambia. Rose (1993) states that "women cannot escape from the 'Woman figure' and this figure gives them a subject position" (p. 11). I should point out here that my positionality is to a great extent influenced by the fact that I am a woman, a label I cannot run away from. I grew up in a patriarchal society in which cultural norms and values firmly place the women in a subservient position to men. Therefore, I would like to contribute to the decentering of dominant power structures (of which male dominance is very prominent) and perhaps contribute to empowerment and emancipation of the marginalized. Schuermans and Newton (2007) claim that there is a notion held by communities and academics in the global South that academics from the North use it as a site of knowledge extraction because the research is usually planned in the North with no or little involvement of participants from the South. They further suggest that a return visit after preliminary findings and analysis is helpful so as to chart practical recommendations for policy makers. I was conscious of the fact that this is how I could be viewed, coming from a University in a developed country to conduct research in a rural area. With this in mind I will endeavour to give the research participants written copies of preliminary findings.

I conducted research in a place where the mine is owned by a Canadian company. With this, I may be unable to conceal my bias and suspicion but nonetheless the fieldwork helped me understand CSR in Zambia as the implementers and recipients perceive it to be. My positionality is multifaceted. I am a teacher, humanitarian, community worker, an evangelical born-again Christian with a deep belief in equality and social justice for all people. I am an advocate of community development and I agree with Kindon and Elwood (2009) on the 
point of researchers using their expertise as advocates. I detest injustice and discrimination in whatever form it may occur. I am a native of the province in which I carried out the research. In addition, I worked in a community in the next district where the local people called me by a nickname of "Mother Theresa" because of the way in which we collectively worked together in implementing water, sanitation, malnutrition and agriculture projects. I was conscious that I did not want to raise expectations and assume a "superwoman" type role, as if I could save local people from perceived social problems. On the other hand, participants viewed me as an emancipator and had certain expectations. I could observe this from the enthusiasm with which they responded to most of the questions. Coming from the capital city and pursuing further studies at a university abroad raised some level of expectation among the participants.

Lastly, I am aware of the challenge it will be to become a voice of representation of the people and also to give them a voice through this thesis and the politics of representation (Palomino-Schalscha 2011). Since feminist epistemology seeks to bring emancipatory social change and empowering virtues to the researched (Habermas, 1972, in Kindon and Elwood 2009), I can be a voice for the community through this research and I hope to contribute to positive development policy and practice change in the CSR context. This is a challenge but it is not impossible. I intend to share this thesis with the community, Barrick Gold and the Ministry of Education. Rose (1997) states that feminist approaches often demand a kind of reflectivity that aims at a full understanding of the researcher, the researched and the research context. I am mindful of the fact that this may not be possible to attain especially within the time and resource limit of this thesis but it is worth trying all the same. I recognize that it will be a long term process of gradual change as people read the thesis and as I evolve in the process.

\subsection{Location}

The data collection was undertaken in Solwezi district in Zambia's North-western province. This is a predominantly agrarian rural area with few schools. It is for this reason that I chose to conduct research in this area because CSR is a major contributor to social services such as education and health for the people. The two schools where I conducted interviews are government/public schools which have dire need of infrastructure such as classroom blocks, teachers' houses and latrines, and have benefitted from CSR projects. School A has a bit more infrastructure and more pupils than School B. School B needs more support. These 
schools also have few teachers due to limited teacher accommodation. I was in Solwezi for one week and I carried out ten interviews and one focus group discussion during this period. I had made prior arrangements and appointments before I travelled from Lusaka to Solwezi.

Barrick Gold owns one of the largest mines in Zambia and it would be expected that they would have a higher per capita investment in the country in comparison to other mining firms. The area has some public schools and few clinics for the community. There is a large workers' complex for mine staff demarcated according to positions in the mine. They have two schools for mine workers one for the white expatriates and another one for the Zambians. The research took place within the community. I interviewed the two staff members from Barrick Gold and Ministry of Education at their offices.

\subsection{Research methodology}

The research is a qualitative case study. Hay (2010) explains a case study as "the study of a single instance of a phenomenon in order to explore in-depth nuances of the phenomenon and the contextual influences on and explanations of that phenomenon" (p. 81). It was chosen as a case study of Barrick Gold's CSR work in one community. Yin (2009) describes a case study as an empirical inquiry that investigates a contemporary phenomenon in depth and within its real life context. I wanted to explore the local people's understanding of the benefits they derive from the mine through the CSR projects in one community. I also wanted to investigate whether the company's CSR intervention in education in particular is benefitting the local community in the best way possible or whether it is tokenism or "gold-plating" with little benefit accruing to the community. By examining how CSR is implemented by Barrick Gold in Solwezi, by asking the locals their thoughts and opinions, I gained insight into how CSR is implemented by Barrick Gold in Zambia and other parts of the world where they undertake similar activities. I was able to gather information on what should be done to improve the quality of benefits from the local people's (the beneficiaries) perspective.

Although feminist research can be done using mixed methods (Kitchin and Tate 2000), this research employed qualitative methods. Given the research questions and approach to privilege the voice of people affected, qualitative methods were most appropriate. In a case study, the inquirer has a set of research questions as opposed to a research objective and these questions revolve around a central question (Creswell, 2009). All my questions revolved around a central phenomenon which is "what benefits from the mine accrue to the local people?" Interviews and focus group discussions were the primary methods and main source 
of information. However, some secondary data was obtained from other sources, namely the school attendance records. The data was obtained from both schools for 2013.

\section{* Research Methods}

Because qualitative approaches require interaction between the researcher and the research participants (Creswell, 2009), I carried out ten face to face interviews and one focus group discussion with 16 people. Therefore the findings are a product of the interaction between me as the researcher and participants. The data collection methodology was interactive. According to Chambers (1983), those who are neither rural nor poor may not know the priorities of those who are. Therefore it was imperative to hear from the people who live and work in this community.

Even though in my mind I would have wanted to empathize with the research participants and situated myself in their context, this was not possible because I was coming from the city and staying at a lodge nearby then going to the community for meetings and interviews. Owing to this, I could not fully comprehend their day to day realities. This is the paradox in which I found myself: on one hand, I wanted to put myself in their situation and feel how they feel and experience what they experience but my circumstances and spatial location was different. Even though this was my predicament, this research sought to examine how the local people who are the intended beneficiaries and the partners, such as the schools and Ministry of Education work and communicate with Barrick Gold as the funder of education projects.

The data was collected through individual interviews and focus group discussions. Both focus groups and individual interviews were semi structured. Hay (2010) defines semi-structured interviews as the researcher having content focused or fully worded questions based on the research question. He further explains that the researcher will have an ordered but not restricted question sequence. Furthermore, Freeman (2006) explains that focus groups are a popular way of qualitative data collection as a particular form of group interview intended to explore people's lived experiences and perspectives. Because I really wanted to get the people's experiences and have information as broadly as I could, I opted to have one focus group discussion with parents and grandparents of the students enrolled in school B, who benefitted from the CSR. I relied on facilitation skills I learnt during my years as a field worker, especially for focus group discussion to stay on the topic at hand and keep the group focused. The interview questions and information sheets are in the appendix. 
Individual interviews were face to face with as much interaction as possible. I used openended question sheets and some of the questions were being reformulated during the interviews (Creswell 2009). The school manager asked one of the teachers, a native of the area who understood the local language to help me write down the responses while I asked the questions. I was speaking in the local language and the participants also responded in the local language but both the teacher and I wrote the responses in English. During the focus groups discussions, I spoke in the local language called Kaonde, and the participants also responded in the local language. Since I can speak but not write in the language, the teacher helped me to write in the local language. The responses were later translated into English. Afterwards we compared our notes to make sure that we had written down all the responses and I subsequently collected all the scripts from him.

Statistical data was collected from the local school for 2013 but they could not seem to find the older records from previous years. My intention was to get data from the 2008 attendance registers (before CSR activities started) and compare with those of 2013 (after CSR started) but the data from previous years was not available.

\section{* Research Participants}

I conducted ten individual interviews in total. The people who were interviewed were; the chief of one of the chiefdoms where Barrick Gold operates, two school managers from two different schools, three teachers (two female, one male), two staff from Barrick Gold (from Sustainability department), two staff from the Ministry of Education working in Solwezi district, in the district education planning department. I conducted one focus group which comprised of people who have children or grandchildren attending school B (eleven female and five male). See Figure 2.1 below for the list of participants and schools where the teachers came from. Due to confidentiality and the fact that it is a small community, I refer to school A and B so that the teachers and school managers are unidentifiable.

The selection of the two schools was based on the information I had on schools Barrick Gold supports. Selection of the school manager was deliberate because I wanted to get first-hand information from the most senior staff member at the school. The selection of teachers however, was done by the school managers. The selection criteria for each focus group participant was targeted towards those whose children or grandchildren who go to the school where Barrick Gold is implementing CSR activities and who have benefitted from the sponsorship. 
For Barrick Gold and the Ministry of Education I chose to interview officers from the relevant departments based on the information I wanted to get. For interviews, the people mentioned above are the primary stakeholders who provided the information I needed to obtain. Hay (2010) states that good projects identify potential obstacles and show what alternatives will be followed should this occur. It took a while for Barrick Gold staff to respond to my emails requesting an appointment but I managed through family connections to find appropriate people. For the other participants, appointments were made via telephone with no hurdles. Although it was the harvest period, the seasonal activities did not affect my appointments with the community members. I was able to meet them at their convenience. I also provided for enough time to spend in the field in order to accommodate any unforeseen circumstances.

Interviews with such key informants were necessary to gain a deeper understanding of their perceptions of the education project and each interviewee had their own perspective based on their experience with Barrick Gold. One to one interviews with Barrick Gold and the education department staff were more appropriate. I used open-ended questions for both one to one interviews and the focus group discussions. Although most of the questions were similar I had a few tailor made questions for the Ministry of Education and Barrick Gold staff, for the community chief and teachers so that I could get more information from their perspectives. 


\section{Figure: 2.1}

Table of Interview Participants

\begin{tabular}{|l|l|l|l|}
\hline Interview & Pseudonym & Gender & Institution \\
\hline 1 & Cobalt & Male & MoE Planning Department \\
\hline 2 & Zinc & Male & MoE Planning Department \\
\hline 3 & Uranium & Male & Chief (one of the Chiefdoms) \\
\hline 4 & Gold & Male & School Manager School A \\
\hline 5 & Silver & Male & School Manager School B \\
\hline 6 & Amethyst & Male & Teacher School A \\
\hline 7 & Amber & Female & Teacher School A \\
\hline 8 & Jade & Female & Teacher School B \\
\hline 9 & Coal & Female & Barrick Gold Sustainability Dept \\
\hline 10 & Copper & Male & Barrick Gold Sustainability Dept \\
\hline
\end{tabular}

\section{Source: Womba Mayondi (2013)}

The interviews worked well and the focus groups were better for the people from the community because they could bounce ideas off each other. This was achieved because people were able to remind each other as they spoke and also emphasize certain points. The parents had a lot to say about the sponsorship that Barrick Gold is rendering to the students and articulate their wish that it should start earlier.

\section{- Data analysis}

All interview responses were coded manually in thematic categories. Crang and Cook (2007) state that it is worthwhile to develop codes that allows analysis and notation of the context of remarks and observations. This helps to avoid producing a cold, over rationalized account that does not take into account the inter-subjective richness of the research encounters (Cook $\&$ Crang, 2007). The broad research questions pertaining to perceptions of the local people and Ministry of Education officers guided how I coded and created categories of the 
responses. In certain situations I have two or three sub-categories. Then I used the categories created to analyse the information and clearly marked the people who said the statements therein. The information was divided into six main categories. These are; access, improvements, communication processes, Barrick Gold policies, motivation and training. WEFT QDA was appropriate as a data analysis tool because it is a free software as opposed to other software packages which are expensive and may be difficult to access outside the university. It is also easy to use. Further, there are resources available online on how to use the software if need arises.

\subsection{Ethical Considerations}

The university requires everyone undertaking research with human subjects to seek and obtain ethical approval before commencing the fieldwork. I obtained ethics approval from the Victoria University Human Ethics Committee prior to commencing my field work. I strictly followed the code of ethics provided by the university for all students conducting field research with human participants. I obtained written consent from each of the research participants. I also explained what the research was all about and why I needed to obtain the information. I explained the information sheet which had been approved by the Ethics Committee. However, despite following the stipulated University Ethics procedures carefully, some ethical dilemmas emerged while I was in the field. I discuss these dilemmas below.

My positionality came under scrutiny at one point during the focus group discussion when one elderly man who had been introduced by the other participants as their leader said "don't waste your time telling her anything, maybe she is just lying and she will not do anything". This made me realize that there was suspicion in the room about my presence and my research in the area and that I could not take for granted that they trusted me wholeheartedly. It was an awkward silent moment, then the conversation continued has if nothing had been said. I was careful not to say anything because either way whatever I said may have been used against me. If I dismissed his assertion publicly I would have given room to raise expectation further that I was going to single-handedly deal with the matter. If I claimed he was right, I would have altered the whole course of the discussion, therefore I decided not to respond to the statement at all. This was a reality check for me because I had thought that since I am also from North-western province, and I am Lunda by tribe, I had expected people to embrace me without suspicion or reservation. Not only that but I had lived and worked in North-western province before and so I thought I would be less likely viewed as an outsider. 
But I realized that with all my good intentions, I still had to be careful and thoughtful with my assumptions and how I conducted the research.

At that point I was aware that my positionality may affect my relations with research participants and their responses. I was also aware that even with the best intentions and wellcalculated activities, my presence created an alteration in group dynamics especially at the local community level. However, I did my best to explain that it was a data collection exercise for my Masters' degree. I did not make any promises whatsoever except that I would share the information they gave me with the Barrick Gold Sustainability Manager. It was a process of constitutive negotiation because of my privileged position and my social identity (Rose 1997). I recognised the need to be humble and listen to their stories, perceptions and aspirations. My desire was that the participants (the researched) and I (the researcher) would be transformed by the field work experience through this interaction and on-going communication.

Another ethical dilemma arose concerning payment which I had not anticipated. One of the teachers I interviewed asked if I was going to pay for participating because she understood that every researcher has a budget and therefore there should be a budget for participants. Added to this, some community members made it clear that they preferred money and not refreshments. I could not argue with them and therefore I had to produce the cash and pay them. Due to my limited budget I negotiated to the lowest minimum they could agree to. I was caught up in a moral dilemma for which there was no easy way out. If I gave money it would have placed me in a position of superiority and this was not my intention. On the other hand had I not given it, it may have brought another dimension of taking people's time and data without compensation.

This payment situation was not unusual. Fortunately or unfortunately, I am not the only researcher who has been there to conduct research. Different kinds of research groups have conducted research in Solwezi and it is a custom to provide compensation of some sort, whether cash, food or drinks. This was an expectation they had because of the pattern that has been set. I chose to oblige and gave cash which I said was for drinks even though there are few shops in the area where drinks can be bought. This was an ethical issue for me because either way I had to do what was "right" at least from the participants' and my perspective and conform to the precedence that has been set by other researchers. I proved Scheyvens' and Storey's (2003) advice that the best way to deal with matters when things go wrong is to have 
an open mind and a sense of humour to be very true and valuable while I was in the field. I also have to constantly think about my motivation for carrying out this research in the first place. I questioned myself if it is ethical to collect information from people for almost nothing except a bit of money for refreshments which may not be commensurate to the time they accorded me for the interviews. I kept these thoughts in mind throughout the whole research journey so that I am constantly thinking about how to be honest and thoughtful as I analysed and made sense of the data.

\subsection{Confidentiality}

I obtained written consent from government and Barrick Gold staff members, school managers, teachers, the chief, and the focus group discussion participants. The data collection was confidential but not anonymous. I did not disclose names of participants but used pseudonyms for those involved in interviews and the 16 focus group participants will just be referred to as participants. The information is grouped and individual people are unidentifiable. Specific details of how many interviews are listed in Figure 2.1 above. I chose confidentiality so that for their safety and peace of mind, all participants will be unidentifiable.

\subsection{Limitations of the data}

I was unable to obtain information from the schools for enrolment and attendance in previous years prior to CSR projects. However, I managed to glean a bit of information from the two schools which shows the figures of this year's attendance. Therefore I cannot make comparisons in terms of what it was before CSR implementation. This information would have assisted me to compare so that I can ascertain in numerical terms how much increase there is in access to education.

\subsection{Conclusion}

My research design and methodology was anchored in feminist epistemologies. I drew on this philosophical approach because they align with my personal values and life experiences. I am also seeking to empower and emancipate myself and the research participants as African people I realize that I stand to benefit most directly from this research through an educational qualification and learning, but by presenting my findings to the authorities, the voices of the participants will be heard. By looking at the literature available on qualitative research in general and case studies in particular, I used the most appropriate data collection tools 
befitting for this kind of qualitative study. I had to fit all the field work into the time and budget available and the focus in questions and prearranged participant appointments helped me to achieve this. In this chapter, I have shown how my epistemology, research methods and data collection tools enabled me to design and carry out the research. I have also explained my positionality and how this may affect my research choices and data analysis. I have also discussed ethical considerations, limitations with the research and challenges I faced in the field. Throughout the data collection, I was able to gain a broad sense of the day to day realities of the people in Solwezi. The following chapter discusses the history and current trends of mining in Zambia. This is the first part of the literature review. 


\section{CHAPTER THREE \\ Mining: History and current development trends}

\subsection{Introduction}

Mining has been a major activity of human existence and has become more prominent during the modern era of capitalism. The previous chapter introduced the methodology and research design of this thesis. This chapter explores the literature on postdevelopment theory which is discussed as a theoretical lens that has influenced this research project. Postdevelopment is critical of the manner in which development policy is formulated and how it is practiced. I also discuss the history of mining on two fronts; globally and in sub Saharan Africa with special focus on Zambia. This chapter discusses key dates in the global mining history, the impact of these events on the mining industry and the implications of capitalism for the mining sector. I employ postdevelopment theory as a development lens through which I analyse various aspects of the mining industry its contribution or negative impact on the community. This chapter is the first part of the literature review, the second part is Chapter Four and it concerns CSR.

The discussion on mining in sub-Saharan Africa also includes the impact of European colonisation. Colonisation was the process of acquiring of colonies in Africa by European states, namely France, Britain, Belgium, Germany and Italy (Rist, 1997). Lastly, the chapter discusses the present legislative framework that governs mining and revenues in Zambia in the post-colonial period. Ferguson (1999) states that the post-colonial era is significant in the mining sector especially for the Zambian context because at independence in 1964, the rights and shareholding of the mines were controlled by the British South African Company (BSAC).

Further on in this chapter I discuss the role of mining in Zambia's economy and its contribution to the national treasury and Gross Domestic Product (GDP). This chapter will also discuss the macro-economic indicators and issues of capital flight in the mining sector. I will also illustrate the costs and impacts of mining in Zambia. I discuss the impact on the environment, people's social-economic status, culture and health in the Solwezi district as a specific case study. Lastly, I discuss the benefits of mining in the Solwezi district, where the concerns around CSR are raised. 


\subsection{Postdevelopment theory}

Postdevelopment is a term that was coined in the 1990s to denote both the failure of conventional post-1945 development, and alternatives to it. The notable scholars of postdevelopment theory whose work I draw upon are; Rist, Escobar, Rahmena, Sidaway and Gibson-Graham. Postdevelopment theory proposes that development is a failed modernity; a set of practices, discourses and strategies institutionalized in the multilateral development institutions which emerged after the Second World War (Johnston et al 2000). Postdevelopment signifies a critique of epistemological categories, hierarchies and assumptions of development discourse (Sidaway, 2007). In using this theoretical approach I am constantly reflecting on the image painted by 'developers' of helpless Third World people sitting down and doing nothing as they wait for the saviour in the name of the Western White Man to bring help, aid or development. As Berman (1982 cited in Sidaway) points out, the developer must be judged by his vision of the world, the new horizons it opens up for mankind and also what he does not see and refuses to look at such as the potentialities it cannot bare to face. My understanding of this statement is that people who live in Third World countries are not a lost cause, but they have potential to contribute to their own 'development' and should therefore be viewed as partners or central actors. This is how and why postdevelopment theory is a lens through which this whole thesis is developed.

Development and indeed underdevelopment add to the creation and construction of these binaries. Rist (2007) explains that the terms development and underdevelopment as we know them today are anchored in President Truman's speech of 1949. The interpretation of development as a trajectory towards modernization is important in order illustrate how postdevelopment as a theoretical framework has shaped this research. Escobar (2004, cited in Gibson-Graham, 2005) argues that modernity can no longer be treated as the Great Singularity and giant attractor towards which all tendencies gravitate; rather it should be treated as a true multiplicity where trajectories are multiple and can lead to different and varied outcomes. Escobar's claim therefore validates the need to explore these alternative models of development that can lead to other outcomes. For the purpose of clarity, this research employs postdevelopment as a critique of the prescribed trajectory of modernization as the sole objective of development. It also questions development as a process which supports and condones the hegemony of the West over the developing countries in the global South. 
The creation of these dichotomies and binaries has been a source of contention. Owing this contention, postdevelopment theory creates an opportunity to question, challenge and indeed deconstruct them. Sidaway (2007) observes that postdevelopment critiques Western notions and assumptions of superiority and expertise that are seen to very often accompany development interventions.

This research is anchored in postdevelopment because of the debate on aid versus trade and a critique of current aid modalities which have done little to alleviate poverty of many African countries. Okonjo (2012) suggests that current aid modalities where donors provide funding for goods and services such as health, education and water, should be replaced by trade so that revenue would give a country income to provide these public goods to their people. Other postdevelopment theorists have criticised the manner in which developed countries lend money to developing countries through IMF and World Bank as a means of development.

If the goals of official debt were to squeeze the debtors dry, to transfer enormous resources from South to North and to wage undeclared war on poor countries and their people then their policies have been an unqualified success. If however the strategies were intended as these institutions always claim to promote development beneficial to all members of society, to preserve the planet's unique environment and gradually to reduce the debt burden itself then failure is easily demonstrated (Rahnema and Bawtree 1997, p. 207).

In addition, the other concern in the postdevelopment debate is questioning the status quo in terms of how development is perceived in general and specifically how policies and procedures governing aid mechanisms affect recipient countries. Gibson-Graham (2005) argues that postdevelopment is not anti-development, nor does the theory see all development, past, present and future as failed: rather, it is a challenge to imagine and practice development differently beyond the limited imaginaries of neoliberal globalisation and capitalism. Rahnema and Bawtree (2007) suggest that postdevelopment is about an endogenous, human-centred, participatory, bottom-up and sustainable form of development. This is the alternative way of thinking about, defining and practising development programmes in which this thesis is anchored. 


\subsection{Capitalism and Colonisation}

Mining is a lucrative venture globally. In many countries where the mining industry is thriving, it accounts for a large percentage of the total national income, and this is inherently linked with capitalism. Capitalism is a specific form of economic and social organization. In theory, it is the singularity of economy in which the direct producer is separated from ownership of the means of production and the separation is effected through the transformation of labour into a commodity to be bought and sold on a labour market regulated by price signals (Johnston et al, 2000). Capitalism created an insatiable appetite for minerals because the wealth of a country was (and still is to a large extent) measured by the mineral wealth it possesses. In 1492 capitalism begun to thrive in Europe with the political revolution that transferred power from the landlord elite to the bourgeoisie (the capitalaccumulating new elite) and this led to the glorious revolution in England in 1688 followed by the Industrial Revolution in the latter part of the 1800s (Bulmer, 2003). Europeans and not Africans or Asians conquered America as part of their drive for minerals.

Owing to the fact that capitalism was thriving from early 1800s until now, more minerals were and are still needed to maintain money-centred economies in the world. For this reason, the search for mineral concentrates has gained momentum. This situation explained above propelled colonisation because European countries needed these minerals from countries in the South. The organization of the colonial economy was always guided by the concept of mercantilism. A nation's prosperity was (and still is) linked to accumulation of capital and capital was tied to availability of precious metals. Since Spain and Portugal had limited supplies of precious metals they relied on supply from Latin America. Through the Trade Deficit Agreement, Spain and Portugal sought to extract these precious metals from Latin America. This is an important historical aspect because colonisation of African countries was motivated by the mineral resources found therein (Bulmer, 2003).

The extraction of minerals from Latin America can be viewed as the beginning of colonialism which eventually spread through other European countries who "acquired" colonies in Africa and parts of Asia. Maconachie and Hilson (2013) have stated that since colonial times, the developing world has served as a resource hinterland for the global capitalist system, driven by unequal terms of trade which have catalyzed transfer of value from poor to rich countries. The insatiable appetite for minerals led Europeans into extensive colonisation of Africa. The colonisation process led Britain, France, Belgium, Germany and Portugal to each "acquire" 
or colonize several countries in Africa. Escobar (1996) argues that colonisation and the expansion of capitalism is a way of imposition of modernity over the rest of the world. Escobar further argues that colonisation and later, development, is about consolidating and supporting the expansion of Western capitalism and wealth so as to civilize and modernize the "backward" and "barbaric" primitives. This illuminates the power imbalance if, from the outset, African colonisation has multiple agendas, it follows that the people are not considered as equal to the colonisers. Zambia was a British colony until 1964 when she gained independence.

Almost 50 years later, the Zambian Government still has to succumb to the dictates of the World Bank, IMF and other donors. The power may look different and be institutional and not governmental, but it is still a power imbalance that is not in the best interests of Zambians. Colonisation has left unequal relations. Carmody (2012) noted a comment made by Hillary Clinton that Africa countries should 'get-over' colonisation. This is a hard statement considering that colonisation may not be over at least not in the real sense. The fact is, other countries and companies need mineral resources to make a profit. Zambia can provide those and the effects of colonisation in terms of who controls how and what is mined and what is done with the profits is still evident today. Clinton's comment seems to elide history, whereas in reality, history affects the present. This thesis is about exploring how this historical colonial and capitalist legacy of mineral extraction affects Zambian people today. Rather than 'getting over it' as Clinton would suggest, I consider exploring it and seeking a better way to extract resources to really be able to rework persistent colonial legacies.

Africa was integrated into the world economy because of the availability of raw materials. Carmody (2012) states that Africa was integrated into the world economy as a supplier of raw materials in the colonial scramble for Africa but today transnational corporations (TNCs) bargain with leaders of these countries to access their raw materials. Colonisation has taken a different form and the geopolitical landscape of Africa is changing as TNCs acquire interests in primary sectors such as oil and minerals in the post-independence era where all countries in Africa are independent. Carmody (2012) observes that on the African continent transnational capital tries to capture resources to meet the needs of global capitalism and the home countries of these TNCs also have a role to play. This makes African countries not only prone to unfair policies to suit the potential investors and their countries but also caught in a crossfire in that there is increasing competition between investors from the West and East. As 
Chinese and Indian TNCs increase investments in Africa in several sectors, there is growing interest for corresponding investment from the United States of America and other European countries.

\subsection{Mining and Development in Zambia}

In Zambia the first mine was opened in a town called Roan in the Copperbelt Province in 1928 and was owned by two private companies, the Roan Selection Trust (RST) and the Anglo-American Corporation (AAC) (Lungu, 2008). These were concessionary companies closely linked to Britain and they were granted monopoly, territorial and exploitative rights by the colonial administration (Carmody, 2012). After independence in 1964, the then Zambian government bought the mine under the Nationalization Policy in 1970 and all rights of ownership or minerals reverted to the state (Auty, 1993). The mining sector experienced turbulent times in the late 1960s when copper prices fell on the LME. This affected copper production and exports negatively. The history of mining in Zambia is essentially about control.

Zambia has rich deposits of copper and relatively fair deposits of gold. Other precious metals are emeralds, coal, cobalt and zinc. The opening of a mine brought about new services and infrastructure development. With it also came some other negative impacts such as environmental degradation, including soil infertility, water and air pollution. Mines are cited as a result of geological circumstances and sometimes this could be in remote areas which were removed from fresh water, good soils, the coast or the navigable rivers that usually contribute to the organic growth of towns (Macmillan, 2012). This means that mines are usually established in areas where population may be sparse and small scale agriculture or other livelihoods are taking place. This meant that the opening of a mine in an area would create prospects of infrastructure development for the mine and other corresponding infrastructure such as housing units, water, sanitation, education, health, and recreation facilities. The mine could bring development to an otherwise rural and isolated region as was the case in the Copperbelt (Ferguson, 1999). This is currently being experienced in the New Copperbelt (Negi, 2010).

In order to reduce operational costs and have a viable mining venture, the Zambian Government needed to put in place a legislative framework that would not disadvantage the 
people but would also give investors the confidence to establish mines. Mining is a speculative business, meaning that there is no guarantee of profit immediately after opening operations. Macmillan (2012) states that mining is the most cyclical of industries because commodity markets are characterized by a pattern of increased demand, shortages, high prices, new investment, increased production and over-supply of minerals. Auty and Mikesell (1998) state that the macroeconomic conditions for sustained growth in mineral-exporting countries are affected by a number of factors. These include: fluctuations in world prices of mineral exports; changes in exchange rates; capital imports and exports; and structural changes affecting the country's capacity to produce minerals.

Many wealthy nations are the producers of finished consumer products, while mineral rich countries export mineral concentrates (usually as raw materials) which are more susceptible to price fluctuations than manufactured goods or services (Macmillan, 2012; Auty \& Mikesell, 1998). Furthermore, Auty and Mikesell (1998) suggest that copper and petroleum display different patterns of fluctuations and prices because of the way they have been governed by the LME for several decades. In my understanding, this shows the interconnectedness of the globe and that resource rich developing countries still need the global system to be favourable in order to benefit from their resources. For example, during the 2008/9 global economic crisis, copper prices fell, as did demand on the world market (Fraser, 2012). The reduction of labour costs in order to lower production overheads was the mining companies preferred option (Auty \& Mikesell, 1998). During the 2008/9 economic crisis there were a lot of job losses in the mines in Zambia in order to reduce overhead expenditure (Fraser, 2012). This had a ripple effect on the exchange rate of the local currency against the major currencies of the world and affected the balance of payments overall. Therefore, mining has a direct correlation to development and macro-economic development at Zambian national level and it is prone to global conditions.

Zambia has been exporting much of its copper as either copperplates or semi-processed concentrate since commercial mining began. There was a national over-reliance on copper, as its export yielded three-fifths of the government's national revenue in the 1960s and 1970s (Auty, 1993). The heavy reliance on copper for export revenue has not changed much in the recent past. Copper and copper products account for almost 80 percent of Zambia's exports (CSO, 2007 cited in Carmody 2009). Although there was nationalization of mines in the 1970s, the mines were privatized in the early 1990s under the World Bank and IMF induced 
Structural Adjustment Policy (Fraser \& Lungu, 2007). At present, mines are owned by transnational private companies, necessitating negotiation between the government and the companies, with tax and royalty payments of central concern to the government. Tax and royalties are a mechanism by which the mineral exporting country can gain income from the mines when they are privately owned. Auty and Mikesell (1998) state that "taxation in mining is complicated because the government may have multiple objectives," (p. 42). These may include: maximizing mineral rents, stabilizing tax revenue and making the mineral industry attractive to investors. These objectives are not necessarily compatible with those of the government and may have conflicting outcomes.

Tax evasion and understatement of profits have been points of contention in Zambia's mining sector. Guy Scott, Zambia's vice president, expressed concern regarding tax avoidance in the mining sector stating that Zambia is losing more money through tax avoidance and transfer pricing than it is gaining from foreign aid (BBC, Why Poverty Documentary, 2012). As an example of this, Glencore, a Swiss commodities trading company which owns Mopani Copper Mines has been cited as depriving the Zambian government of large amounts of money through transfer pricing and tax evasions, (BBC, Why Poverty Documentary, 2012). The picture may be no different in other mines because profit making seems to be of paramount importance to the industry.

The other forms of revenue for a mineral exporting country is the upfront payment which the investor pays before they start mining and the resource rent they pay for as long as they are mining (Auty \& Mikesell, 1998). However, even though taxation, royalties, resource rents and upfront payments are guiding principles for maximizing revenue for the country, the reality is different. For example, the Mines and Minerals Act (1995) specified that mineral royalties should be three percent for those holding large-scale mining licenses but the rate negotiated by most mining companies was 0.6 percent which is the current rate being used. The Mines and Mineral Act is an act of parliament passed in 1995 to stipulate obligations of investors in the mining sector and the government of Zambia. The companies were also granted 100 percent deductions of capital expenditure which exempted them from paying customs and exercise duty as well as import tax on all machinery and equipment (Lungu, 2008). Thus, it would seem that the mining sector gets added incentives to operate in Zambia, at a cost to the government. 
The feast or famine nature of income from minerals on the global market gives Zambia an unstable revenue base. For this reason, Lungu (2008) suggests there is an urgent need for the country to embark on a long-term development agenda that will lead to sustained growth and development. The diversification debate needs to be rekindled so that other sectors such as agriculture and manufacturing can also contribute to development to cushion the sole reliance on mining. In my view, both agriculture and manufacturing have the potential to provide an alternative to mining. It is worth noting that Chinese investment in Zambia has increased in the agriculture, manufacturing and mining sectors. Fraser (2012) states that Chinese investment in Zambia grew during the 2008 economic crisis and still continues to thrive even now especially in the extractives industry. Chinese investors continued lending when credit from Western Banks dried up.

Global geopolitics is at play with such negotiations, and definitely there are those who are more powerful than others. In my view, the transnational mining companies and the countries they represent are certainly more powerful than the Zambian Government and this renders the negotiation table uneven. Mususa (2012) states that during the colonial period in Zambia, mining companies paid mineral royalties to the British South African Company (BSAC) of 13.5 percent, export tax of 40 percent and corporate tax of 45 percent. The paradox is that at present, after privatisation, the taxes that are being paid are lower. Even though the tax required by law is insignificant, companies still find a way to pay less or nothing at all.

Between 2001 and 2008, the copper price on the LME quadrupled but investors in Zambia paid virtually nothing in profit taxes (BBC, Why Poverty Documentary, 2012). This has a link to postdevelopment discourse in terms of the relationship between the developed countries and the least developed countries. Who stands to gain the most in the privatisation or better still, the international trade agenda? From a postdevelopment standpoint, the legacy of Western hegemony is apparent in the privatisation process. Western domination can be clearly seen, assuming that the majority of shareholders of the TNCs who buy mines in mineral rich countries are Western men such as Peter Munk CEO and founder of Barrick Gold, and Clive Newall President of First Quantum Minerals. One vivid case in point is how Glasenburg, the CEO of Glencore earned US $\$ 880 \mathrm{~m}$ in one day when Glencore went public in an Initial Public Offering (IPO) in 2012, and the mayor of Rueschlikon (in Switzerland) the city where Glasenburg lives had to lower the tax percentage. This was because the money that Glasenburg would have paid in taxes would have been much more than the local 
government can spend in a city where unemployment and other social problems are nonexistent (BBC, Why Poverty Documentary, 2012). This shows the power imbalance between the Zambian government and Western countries.

During the late 1960s, the mines were not making enough profit and production was low owing to decline in capital investment and other inefficiencies on the part of the government. Because of this, there was need for recapitalization and since the government at that time, during the 1970s and 1980s, controlled the major shareholding, but could not afford to inject more money into the mines, privatisation was inevitable (Lungu, 2008). Privatisation led to the dismantling of Zambia Consolidated Copper Mine (ZCCM) and different companies bought different mines or at least acquired majority shareholding. The Anglo American Corporation acquired 65 percent of Konkola Copper Mine, Glencore (Switzerland) acquired 73.1 percent of Nkana and Mufulira, and the Binani Group of Companies (United Kingdom) bought 85 percent of Luanshya formerly Roan Copper Mine (Lungu, 2008). During privatisation, keeping the up-front and royalties payment and tax regime attractive for investors was the Zambian government's goal. The copper mines where sold for a total of US\$ 627 million but in subsequent years minted a total of US\$600 million in profit (BBC, Why Poverty Documentary, 2012). Much as I agree that the mines where not viable in the business sense, I also think that privatisation in terms of prices, taxes and royalties favoured the investors more than the Zambian government.

From the early 2000s the Copper prices have been favourable and new mines have opened in Zambia within the last 10 years. Lungu (2008) suggests that copper production has increased partly due to the opening of new mines, and if China's appetite for mineral resources continues rising, the price may be favourable for some years to come. Currently the copper price is US \$7,276 per ton (Bank of Zambia, 2013). This is a higher price in comparison to the price drop from the mid-1970s through to early-1990s.

Mining can have both negative and positive development outcomes, and I will now discuss some of the positive outcomes. Mining was a big contributor to infrastructure development in Zambia. The whole Copperbelt Province which consists of several towns which were built with funding from the mine. The first mine was opened in Roan (now called Luanshya) but mines soon opened in other cities such as Ndola, Kitwe, Chingola, Mufulira and Chililabombwe. Housing units for staff and infrastructure for mining as a whole were 
required. Macmillan (2012) states that after the Second World War, the government of Zambia began to make large-scale provision for family housing motivated by the need to create a stable and more highly skilled workforce. By the early 1970s, Zambia was the most urbanized country in Southern Africa outside South Africa. Figure 3.1 below shows the map of the Copperbelt towns stated above.

\section{Figure: 3. 1}

Map of the Copperbelt

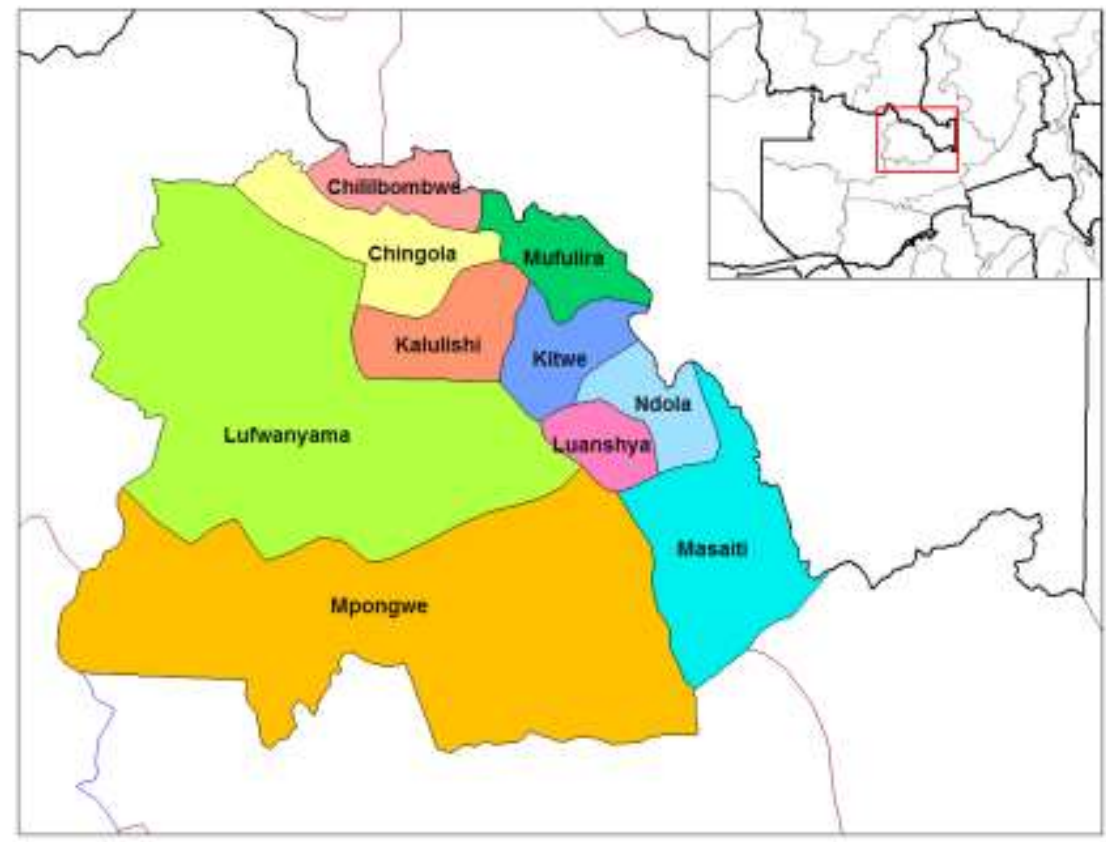

Source: Wikipedia (2013)

Copper mines have made a significant contribution to Zambia's development. Lungu (2008) states that the private mining companies provided orderly residential housing, food rations, hospitals, schools, and recreation facilities for employees. He also states that the mine provided 'cradle to grave' type of welfare to the employees which ranged from infants' nappies to funeral arrangements for the dead. This welfare type of mentality was a political move to conform to the then President's Kenneth Kaunda's humanist philosophy. In my opinion, while I appreciate the intended goodness of this humanistic approach, the consequences of inefficiency in businesses became more detrimental to the Zambian people because many nationalized companies could not sustain profits due to poor management and lack of diversification of the economy. Therefore it created more poverty than it was trying to curb because when the copper prices fell then the whole national economy was affected because development and mining profitability were tied to global markets. 
The growing mining industry and somewhat stable copper prices kept the urbanisation of the Copperbelt towns thriving during the 1930s to 1960s. Ferguson (1999) recalls Zambia at its independence in 1964 was a highly urbanized nation and newly so because the mining towns sprung up on the Copperbelt and symbolised newness in a way that old towns could not. Macmillan (2012) notes that, by the late 1960s, Zambia's copper miners were the best-paid workers in Black Africa. The urban population grew rapidly due to higher wages, and other policies such as food subsidies encouraged a rural exodus as many people came to the city to seek jobs in the mines and other related industries (Ferguson, 1999). Mususa (2012) states that conditions for the African workforce in the mines improved and the mining companies provided an opportunity to progress into skilled jobs under a policy of Africanisation which sought to empower Africans with appropriate skills, to take on skilled jobs because they were a cheaper source of labour than their white counterparts. This also illustrates issues of Western hegemony.

Historically, mines needed to pay workers, taxes, royalties, repay capital investment, provide a return to investors and generate funds for development (Macmillan, 2012). This was not an easy matter because the mine had to be viable and make profits within a short period of time if it was to sustain business. Macmillan (2012) also states that in order to do this, they required small quantities of expensive skilled labour, with large quantities of cheap, unskilled labour in order to make high rates of profit. Therefore, "in Zambia the only option was for the government to accept expatriates to come and work in the mines, because from 1930s to mid1970s, few Zambians were sufficiently literate or skilled to fulfill the job requirements" (Alstine \& Afionis, 2013, p. 366). However, Zambians did provide mass numbers of unskilled labour. It is a widely held view among the Zambians who worked in the mines in those days that this created inequality among staff and it was viewed as a form of continued colonisation even after Independence. For example, I met one elderly man during my field work and we got talking about my topic. He had worked in the mines from 1960 to 1980s and recounted how difficult it was to work with European colleagues and also he recalled how that the recreation, housing, education and health facilities where different for Africans and Europeans and this continues today. The employees were and still are aggregated in terms of race and class. Another woman I met (with whom I had an informal conversation), whose husband works for Barrick Gold explained that their children go to a different school than those of the non-African workers and they have different medical facilities and housing. This 
demonstrates the fact that race and class still play a major role in the labour issues in the mine.

The Copperbelt province had good times as well as bad. This seemingly blissful moment would be the norm, for as long as copper prices were high, demand outweighed supply and there was no depression in the global economic arena. I can see a similar trend with what is happening in the new Copperbelt. Barrick Gold even claim to have a local empowerment policy in which a certain quota of employees is allocated to Zambians. Fraser (2012) note that the opening up of new mines in Solwezi has created roads, schools and other infrastructure where before there was only bush. However, the good times are temporary and the residents of Solwezi cannot relax in this current situation. In addition, Konkola Copper Mines (KCM) in neighbouring Chingola has also announced job cuts for 1503 employees citing depletion of copper deposits and a shorter life span remaining for the mine (Zambian Watchdog, 2013; Zambia Weekly 2013). There are also media reports that Barrick Gold will also lay-off 73 staff members in order to cut down on over-heads due to high production costs (Zambia Weekly, 2013). It appears that it is a double bullet for the Zambian middle working class in mining towns. This is because their fortunes and livelihood is so intricately tied to one sector, so they are heavily affected by the rise and fall in the industry. In effect they are dependent on mining.

The mines are currently privately owned. Return on investment in mining fluctuates due to several factors such as copper prices on LME, the global real estate industry and demand for copper. The favourable copper prices and demand of the commodity do not last forever. The situation begun to deteriorate during the mid-1980s when copper prices fell and production also fell (Macmillan, 2012). It is worth noting that those who are happy with the process of urbanization as a result of the mines would have to wait for the next phase of the cycle when copper prices would increase, production and demand would increase as a result of this. Until the early 1990s, there was little recapitalization in the mines. Production reduced from 760,000 tons per annum in 1969 to 257,000 in 2000 (Macmillan, 2012). With this, the service delivery of other social services reduced. If the copper prices fall on the LME, this situation will recur in Zambia. This pattern of cyclic development that relies on one industry's fortunes is disempowering for the local Zambians. This is because when there is any shift in the mining industry in terms of prices, or less demand then the whole economy is affected and the effects are felt among the people. 
This cyclic nature causes negative effects, the major ones being the shrinking of the workforce, deterioration of infrastructure such as housing, health, education and recreation facilities due to lack of maintenance. These can result in health and social issues being affected and the continued increase of HIV and AIDS has been attributed to the mining industry's cyclic nature because most of the workforce is migrant, whether from other towns or other countries. They come to work in the mines and only return to their towns or countries during vacations. Zambia's economy was dependent on mining and still is even at present. There is little, if any diversification into other sectors and this is a major issue. Lungu, (2008, p. 403) states that mining was treated as a "cash cow" by the government. As Zambia is landlocked, mining companies have developed transport infrastructure because mineral concentrates are hauled by road to the nearest port either through Tanzania to Dar-es-Salaam or through Zimbabwe to Durban. Owing to this, there is need for support from neighbouring countries especially Tanzania, Namibia, Zimbabwe and from South Africa as well because some copper is transported to Durban, the busiest port in Africa. Sachs (2005, in Carmody, 2012) states that Africa is not only cursed by its resources but also by its geography and bad neighbours because for as long as the continent does not have appropriate infrastructure it will be by-passed by the market. However, I should note that so far Zambia has benefitted from the amicable relations with countries mentioned above and the minerals are exported to the outside markets through various ports.

\subsection{Mining and Structural Adjustment Programmes}

Minerals are formed underground as a result of a geological accident. This may be a good accident because it gives a country or place a resource which if managed properly can be of great benefit to the people. At the same time this accident of nature can bring about conflict, strife and other social and environmental impacts. It may not give the place or country the much needed revenue. It becomes a "resource curse" (Auty and Mikesell 1998, p. 13) because instead of the mineral resources precipitating social and economic good, they cause more poverty. Wilbur Simuusa, former Mines minister in Zambia observed during an interview that Zambia has an abundance of mineral resources yet it is among the bottom poor 20 countries of the world (BBC, Why Poverty Documentary, 2012). This is a very bitter pill to swallow for me as an African, as my country is rich in nature, but for human reasons cannot claim to be rich economically. 
The resource curse thesis has been discussed by several authors. For example, Carmody (2012) states that the paradox of plenty or 'resource curse' is that Africa is mineral rich with 90 percent of the world's platinum, 80 percent of the world's coltan (an essential metal for manufacturing electronics such as mobile phones, laptops and other hand held devices), 40 percent of its gold and 30 percent of the world's mineral reserves overall, but it is the poorest and most conflicted continent in the world. We are so rich, yet so poor. Graulau (2008) argues that for most countries, the discovery of minerals was a matter of chance and or luck. The discovery and use of minerals changes the economic landscape, creating a ripple effect on development. The cardinal point is; the revenue that the mineral rich country can derive through taxes, royalties and other payments gives the country the ability to fund social programmes such as education, health and agriculture. Discovery of minerals, whether gold, diamonds, platinum, copper or oil, may have seriously distorting effects on economies. It is how and by whom the revenue that is gained from mineral extraction is managed that determines the wealth of the country.

During the 1980s and 1990s much of the Third World undertook SAPs. Carmody (2011) states that SAPs promoted by World Bank and IMF centred on liberalisation, privatisation and state cut-backs and retrenchment. The World Bank and International Monetary Fund (IMF) imposed several reforms and conditions which the Zambian government could not avoid but had to adhere to. These reforms were: privatisation, trade liberalisation, banking sector reforms and petroleum price changes (Harris \& Kende-Robb 2008).

Privatisation in Zambia was done in such a way that the government did not have much choice over the matter. The former Minister of Finance for Zambia stated in an interview that the manner in which privatisation was done was like someone pointing a gun to your head and coercing you to privatise (BBC, Why Poverty Documentary, 2012). These structural changes at a macro level would have been imposed with good intentions because from independence in 1964, until the new government was ushered into office in 1991, the Zambian government ran a tightly controlled state-led economy with little or no room for the private sector. However, some of the results of these structural changes were job losses and retrenchments, exclusion of the poor and remote (rural) populations and increased utility fees for necessities such as water and electricity as well as increased user fees in education and health (Harris \& Kende-Robb 2008). Provision of welfare services fell into the hands of civil society (Murray \& Overton 2011). Even though these outcomes were a stark reality in 
Zambia in the years that followed the privatisation and liberalisation process, the Zambian government had no way out but to oblige. This is a good example of unequal power relations and inequality especially for the rural population of a developing country.

It is these arguments of a different and perhaps better way of development policy and practice that has influenced this research. This background supports the argument that development should not lead to a single idea of one trajectory but there should be alternative ways of development policy and practice with other varied outcomes. The question of development being dominated by the West is also a point of reference especially when we consider how privatisation of the mines in Zambia was handled and who stands to gain more in the long run. Lungu (2008) states that after the World Bank pushed the Zambian government to sell assets quickly in the early 1990s, the government found itself in a weak position because they needed to establish an attractive environment for investment and the mines needed recapitalization. The Zambian government had no choice but to oblige with the Bank's proposals no matter what the consequences would be. Fraser (2012) points out that International Monetary Fund, World Bank and international donors foisted liberalization upon Zambia without ensuring adequate safeguards and this led to the destruction of the social structure of the mining industry and untold human suffering. Murray and Overton (2011) explain that poverty elimination was not an explicit concern rather it was believed economic growth would eventually filter down to the poor but these reforms created new forms of poverty and inequality. The suffering was as a result of job losses, welfare cuts and the discontinuation of social services.

The uneven power structures are starkly evident in the case of mineral royalty negotiations. For example when Vedanta Resources, purchased Konkola Copper Mine the mineral royalty rate that was paid to the Zambia Government was 0.6\%. Carmody (2012) notes that "at the advice/insistence of World Bank the mineral royalty rate was set at 0.6 percent giving the Zambian government US\$12 million in 2006 out of the US\$ 2 billion in copper extracted that year" (p. 100). Therefore, postdevelopment theory is a relevant theoretical framework for this research because it questions the power imbalance and perceived definitions of poverty and the solutions thereof and the role of different actors. It also questions the outcomes of development policy and practice as prescribed by the West, and carried out by the financial institutions. 


\subsection{Current situation in Zambia and macro-economic policies}

As highlighted above, if demand or price for minerals drops the effects are detrimental to mineral dependent economies. The slowdown in the Zambian mining industry continued from late-1960s until the early 2000s. During the early 1990s, the mines were privatized under the (SAPs) which favoured a free market and liberalized economy. At the time of writing, the copper prices are favourable on the LME and production is increasing in Zambia. All mines are owned by private companies from different countries. Zambia Consolidated Copper Mines (ZCCM) which is the shareholding company on behalf of the government owns minority shares in some of the mines. Lungu (2008) states that First Quantum Minerals a Canadian-based company owns 80 percent of Kansanshi Mine PLC and ZCCM owns the remaining 20 percent. The company is listed on the Toronto and London Stock Exchanges. Barrick Gold, based in Canada, owns Lumwana mine where the case study for this research was done.

Zambia is striving to achieve the Millennium Development Goals (MDGs) and education is one of the key sectors among others. As has been highlighted above, over 70 percent of funds in the national treasury come from mining exports, taxes and royalties. Copper is the major export earner for the country and diversification into other primary products are still under discussion. There are some exports of vegetables and flowers to Europe and New Zealand respectively. However, government policy will remain focused on diversifying the export base through supportive interventions in economic sectors and activities with the greatest potential for exports (Bank of Zambia, 2013).

Copper is the highest contributor of total Zambia's exports. Figure 3.2 shows export in percentage. The copper exports in comparison to other goods between June and September 2013. Consumer goods are mainly flowers and vegetables and raw materials are usually cotton and timber. Table 3.3 shows the various destinations of Zambia's exports. Switzerland is the major importer followed by China. These figures show the heavy dependence on mining for Zambia. This research concerns how the mining industry affects development through CSR and a case study of mining in the Solwezi District is used. The tables above illustrate the scope of mining industry in comparison to other industries in Zambia. They also show the interconnectedness with other countries, mainly the export market. Switzerland is 
the highest export destination and it is noteworthy that Glencore, the largest commodities trader which buys and sales much of the copper from Zambia is a Swiss company.

\section{Figure 3.2}

Zambia exports

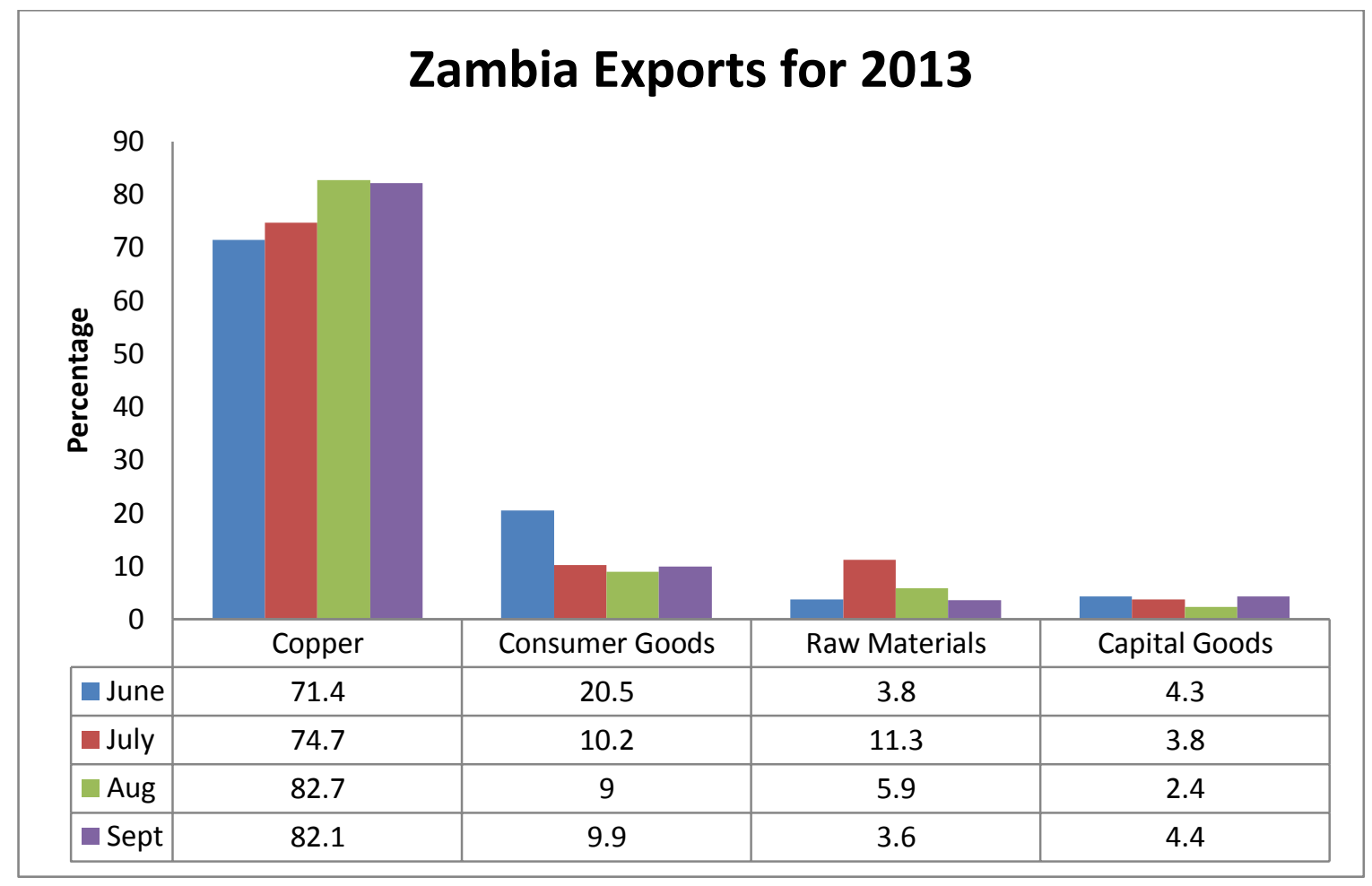

Source: Zambia CSO Monthly Bulletins; September \& November (2013). 


\section{Figure 3.3}

Export destinations of copper exports by percentage.

\section{EXPORT DESTINATIONS BY PERCENTAGE}

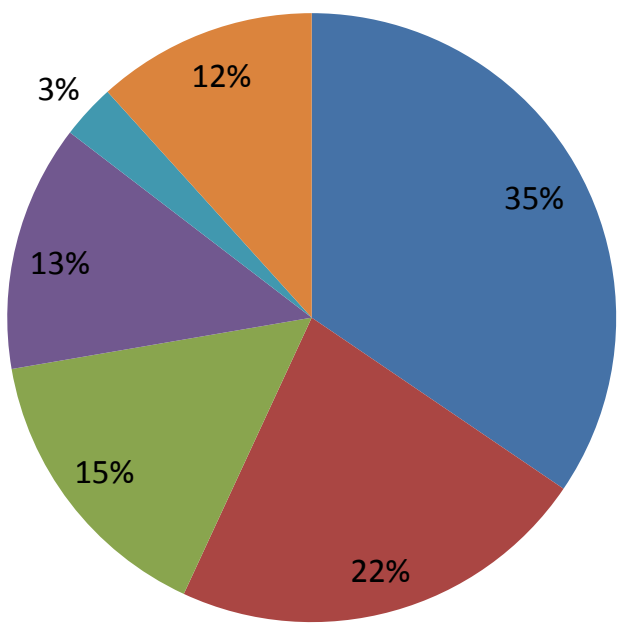

- Switzerland

China

- South Africa

- Congo DR

- UAE

Other EU Countries

Source: Zambia CSO Monthly Bulletins; September \& November (2013).

\subsection{Mining in Solwezi}

The case study was undertaken in Solwezi where Barrick Gold, the largest gold mining firm in the world is the owner of the copper mine. It is worth noting that there are two big mines in Solwezi and the other one is owned by First Quantum Minerals who, like Barrick Gold, are also Canadian-owned. The presence of these two mines has transformed the once small rural, agrarian community into a vibrant town with modern houses and tarmac roads. Larmer (2012) states that a whole new town with roads, hospitals, electricity and thousands of jobs has emerged in the area that was once only bush. This discovery of minerals has altered the outlook of Solwezi in the same way that the original Copperbelt changed during the 1950s. The transformation has been both good and bad for the people and the environment. Urbanisation in terms of having modern housing and other social housing has been one of the positive impacts of the mines. The other is the economic benefit of wholesale and retail trading and service industries such as hotels and lodges that are feeding off the mines because of a high number of people coming to the area for work and business. However, mining also creates several negative social, environmental, health, HIV and AIDS, and political impacts. One man told me during an informal conversation while I was in Solwezi that they do not fish as much as they used to in the past because the fish stock has reduced in the river and 
they have also experienced a reduction in crop production due to water pollution. Lifestyle and cultural changes are evident, although not always measured by studies.

Culturally settlement patterns and the rural way of life have been altered. The communal and interdependent type of life style which characterized rural settings in this part of Zambia is slowly changing and giving way to individualistic and independent types of lifestyle. People also have to accommodate others who are coming in search of jobs and business opportunities from other parts of the country. Binge drinking on pay day and alcoholism have become rampant because now people have some disposable income which they never had before. This is due to the fact that some have been employed by the mine either as casual or full-time workers. Others are trading because some money has been introduced into the economy owing to employment and other contractual activities. Politically, strife and conflict over land rights at local government and traditional level has increased. There are several disputes pertaining to resettlement wrangles with those people who have been displaced to give way to mining needs and they are still awaiting compensation (Alstine \& Afionis, 2013)

Mining definitely changes the environment of a particular place. Auty and Mikesell (1998) state that mining changes the primordial state of the earth, and has an adverse impact on groundwater and adjacent streams. This has affected the agricultural output in Solwezi. The air has also been affected due to the release of fumes into the atmosphere. This is particularly dangerous for Solwezi district because the population depends on underground water and perennial rivers for all their daily water needs. Although not much evidence has been documented in Solwezi on the environmental impact of mining, people of Copperbelt province experienced considerable environmental problems. For example, Fraser and Lungu (2007) state that mining has created significant air and water pollution in the Copperbelt towns due to excess sulphur-dioxide emissions from smelting, silting of rivers, dams and metal effluents discharged through the rivers. In an incident in 2008, hundreds of residents of Kitwe town were treated at the hospital for assorted diseases due to contaminated water from sulphuric acid which leaked into the main water system (BBC, Why Poverty Documentary, 2012, Carmody, 2012). General health has been affected by air pollutants from the mine. There are more cases of respiratory diseases. The water utility companies treat contaminated water and they pass the cost on to consumers through higher water bills (Fraser \& Lungu 2007; BBC, Why Poverty Documentary, 2012). This is likely to be the case in Solwezi in the 
next few years unless development agreements are enforced or the government and mining companies take the initiative to clean up the air and water.

HIV prevalence and other sexually transmitted diseases are attributed to migrant workers because men and/or women leave spouses in their place of residence to go and work in the mine. The issue of spouses being separated is a serious issue in sub-Saharan Africa because it is a widely known fact that two thirds of the people living with HIV in the world live in this region. The other impact of mining is the influx of commercial sex workers who has come to Solwezi from other parts of country to seek a living because of the perceived higher cash economy which may not be the case in other towns. Solwezi District provides a good case study for analysing how the mining sector affects people and the environment in Zambia, a country for whom the legacy of colonialism is still present.

\subsection{Conclusion}

Mining has been part of human history for many years. In the last few centuries it has become a source of wealth for many countries whether they have minerals or they buy mineral rights from resource rich countries. Zambian mines were privately owned during the colonial era, then nationalized after independence and the present scenario is that private investors are the majority shareholders. Although mining is a cyclical and highly speculative venture, this neither deters countries from purchasing mines or mineral rights nor prevents those who have the minerals from relying solely on them for their sustenance. In this chapter I have traced the history of mining globally, and within the African region as well as Zambia. I have also discussed the complex correlation between mining and wealth creation for the country in form of taxes and other payments. There is a growing debate that if corporations pay the appropriate taxes, rents and royalties then the government should have enough revenue to provide the public goods and services such as health, education, water and sanitation. I have also mentioned the power struggles which the Zambian government found themselves in during the privatisation of the mines and how Western hegemony created an uneven platform to negotiate. The control of the mines, due in part to the expertise of Western mining officials, has not changed. The profits still flow out of Zambia to other countries and corporations. I agree with the proponents of postdevelopment discourse in questioning and challenging the binaries and dichotomies created by the way in which the West identifies and defines poverty and their prescriptions of solutions. This chapter responds to research question one on the history and current role of mining in Zambia's development. In the next 
chapter I will discuss the literature on CSR definitions and key debates. I will also discuss CSR and education in Zambia. 


\title{
CHAPTER FOUR \\ Mining, Corporate Social Responsibility and Education
}

\author{
"State weakness invites external exploitation and much of Africa represents a power \\ vacuum that predatory outsiders are only too anxious to fill as they search for \\ resources in an ever competitive world" (Arnold 2009, in Carmody 2011, p. 14).
}

\subsection{Introduction}

The mining industry has contributed to the economic development of most countries in the world as a lucrative source of income. The economic boom has been experienced by the countries that have mineral deposits, as well as those organisations (public and private) that have little or no deposits but acquire rights to mines in other countries. Arnold (2009) as stated above, points out the power vacuum in Africa which refers not only in governance issues but also economic and social issues. Geologically, most African countries are rich in mineral deposits but they do not have enough capital to mine and process the minerals. In addition, there is external and international pressure to involve foreign investors in the mining sector so as to become part of the global economy. Foreign Direct Investment (FDI) in the mining sector has increased and China, Canada, and India are the most prominent investors today (Fraser, 2010; Carmody, 2011).

The previous chapter discussed the different stages of the mining sector over time in Zambia and how currently more still needs to be done to ensure that the national wealth derived from mines 'trickles down' to the local community. Solwezi is the provincial capital of the Northwestern province of Zambia. This was once a serene agricultural based town. It has come into the spotlight because it is in the 'New Copperbelt'. The Zambian government has also discovered oil and gas in the area but extraction has not yet begun (Fraser \& Larmer, 2010; Carmody, 2011). The economic vibrancy of Solwezi amid stark poverty, and the two mines operating, interested me and was the impetus for this thesis and in the following sections I discuss mining, CSR, and education efforts as part of CSR, with respect to Solwezi.

This chapter discusses the literature on CSR. It traces the history of CSR as a concept. I discuss definitions from various authors, providing examples from various countries and different corporations. I explore different approaches to CSR in Zambia based on available 
documented research. Lastly, I conclude with why CSR is vital for the mining communities in Zambia, especially in the New Copperbelt where new mines have opened and where access to education is still limited.

Globally Corporate Social Responsibility (CSR) has emerged as a favourite topic in the management of corporations, both large and small, since the 1950s. In Zambia, it can be viewed as a means of financing development projects in the community (Lungu \& Mulenga, 2005). Development projects may include: environmental management (such as tree planting and water purification), water supply initiatives, housing, electrification, education, health, HIV mitigation, and microfinance schemes. CSR can provide a platform for the private sector to intervene in the service delivery of public goods that, in most cases, governments in developing countries struggle to provide. CSR is carried out in many parts of the world, especially in many developing countries where the need for social services is often greatest (Cramer 2006; Wall 2008). CSR is viewed, understood and practiced differently in different contexts. In Zambia for example, CSR projects are implemented by mining companies, telecommunications companies, banks, retail chain stores and hotels. In my observation, each of these entities has a different approach to CSR and their projects and priorities vary.

There has been much debate about whether or not non-renewable resources can be mined sustainably, due to the extractive nature of the industry. It is worth noting that this argument has been raised by academics, local communities, local and central government, in addition to international agencies such as the United Nations. Valid as the argument may be, it has not deterred investment in mining. On the contrary, mining has become one of the major economic drivers of the global economy, whether for minerals, oil or gas. Transnational companies mining in either of these items have embarked on Corporate Social Responsibility (CSR) as a way of supporting the community in the area where they operate (Lungu \& Mulenga, 2005; Banks et al, 2013; Gilberthorpe 2013). CSR is also a means partly to address this issue of sustainability of the benefits to the community after the mine stops operating in the area (Gilberthorpe, 2013). 


\subsection{History and definitions of CSR}

The history of CSR can be traced back to the 1950s. Petrick (2009) states that CSR has been discussed throughout the $20^{\text {th }}$ Century, but it was Bowen's book written in 1953 that started the modern debate. Bowen (1953) reasoned that general social and economic benefits would accrue to society if businesses recognised broader social goals in their strategies. Over the last 50 years, CSR has gained prominence among business managers from corporations of all sizes. It has evolved over the years as a concept, a model and in how it is practised.

There is no one agreed definition of CSR. It is a contested term which "means something but not always the same thing to everybody" (Idemudia 2008 cited in Kiikpoye 2012, p. 261). There seems to be an unwritten social contract that when companies extract minerals, oil or gas from an area, they should engage in or fund social activities which are a way of giving back to the community. From the community perspective, relationships between the extractive industries and the community are symbolized by unfulfilled great expectations (Kemp, 2009, as cited in Alstine \& Afionis, 2013). Although the stakeholder theory position argues that business has a duty of social responsibility to stakeholders beyond profit and the production of goods and services (Kiikpoye 2012), sometimes communities find themselves in a weaker position in that their wishes are not heard by the transnational corporations. The result is that many transnational companies engage in CSR in order to alleviate the poverty of the local community but the quality of development outcomes may be far from satisfactory. For example, previous research in Solwezi shows that the community appreciated the support Kansanshi mine is rendering to education but they still expressed concern in relation to unfulfilled promises of a better livelihood albeit by informal agreements (Alstine \& Afionis 2013).

Corporations give portions of their profits to poor communities, in order to promote development of the communities in which they work. CSR is broadly defined as "doing good" where the wealthy assist the poor and less privileged (May et al, 2007; Bendell, 2005). The World Business Council for Sustainable Development defines CSR as the continuing commitment by business to contribute to economic development while improving the quality of life of the workforce and their families and the community and society at large (Haalboom 2012). All these definitions from various authors and entities recognise the need to bring people to the fore be they workforce, families or the wider community where the company is 
situated. Carroll (1991, as cited in Yakovleva et al, 2008) analysed CSR practices and categorised them into four main segments: economic, legal, ethical, and philanthropic (see Figure 4.1). According to Carroll's model, corporations are driven by any part of the triangle and they may be more profit driven than ethical or philanthropic. Others would place emphasis on the ethical and good corporate citizenship aspects. It is worth noting that whatever the motivation to undertake CSR, it does make some difference in communities especially where the need for social services is dire. According to Carroll's model below, the most important aspect of a company is economic and this is the foundation for everything else. The pyramids below illustrate the suggested model within which CSR should operate in companies. The most important is the bottom section of the pyramid because it is the basis for why the business exists in the first place, to make a profit.

\section{Figure 4.1}

Carroll's 1991 pyramid

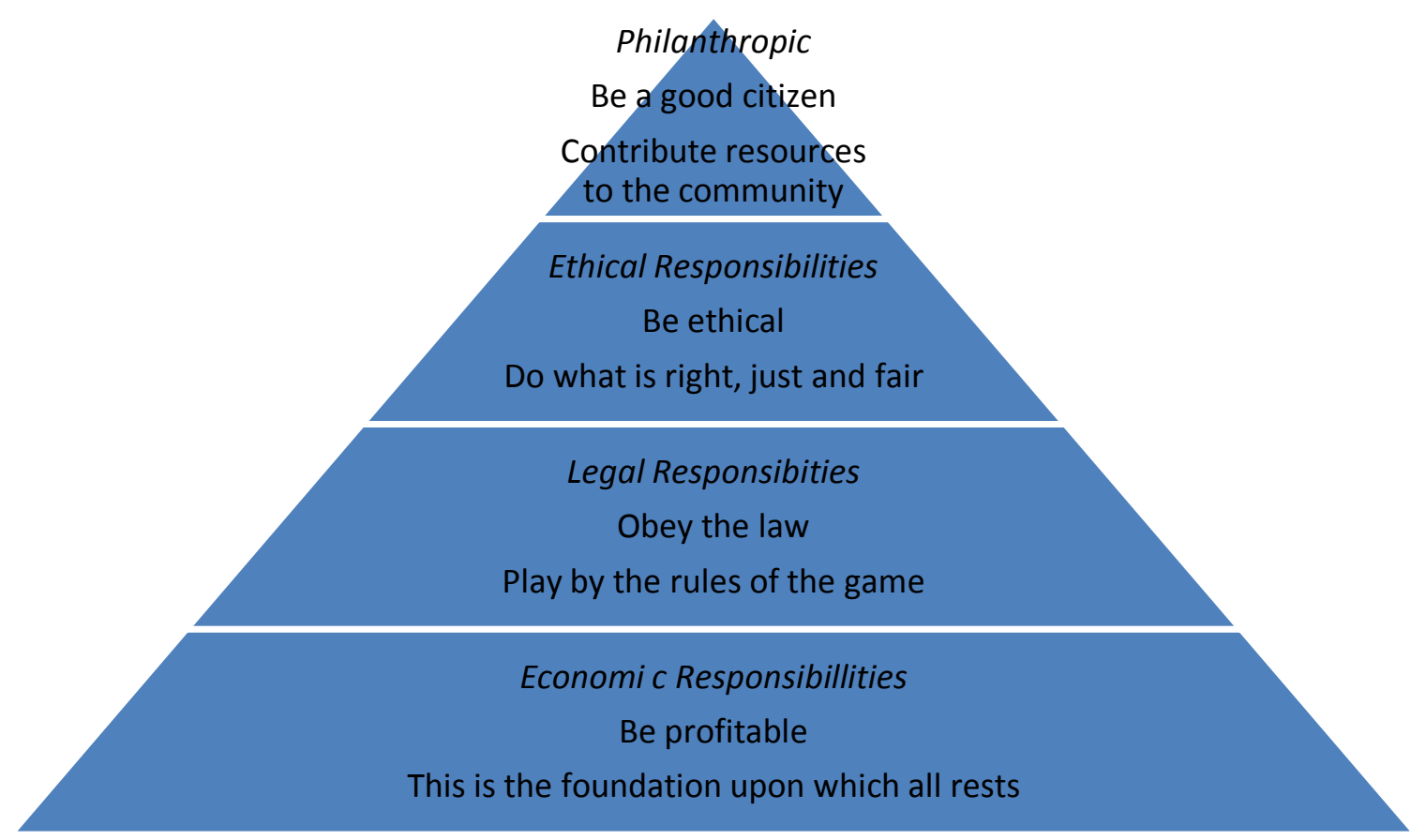

Source: Yakovleva et al (2008)

Visser also developed a similar model in 2008. In his model, (see Figure 4.2) the economic responsibility is also the bottom line. It is followed by philanthropy, legal and ethical responsibilities. 


\section{Figure 4.2}

Visser's 2008 pyramid

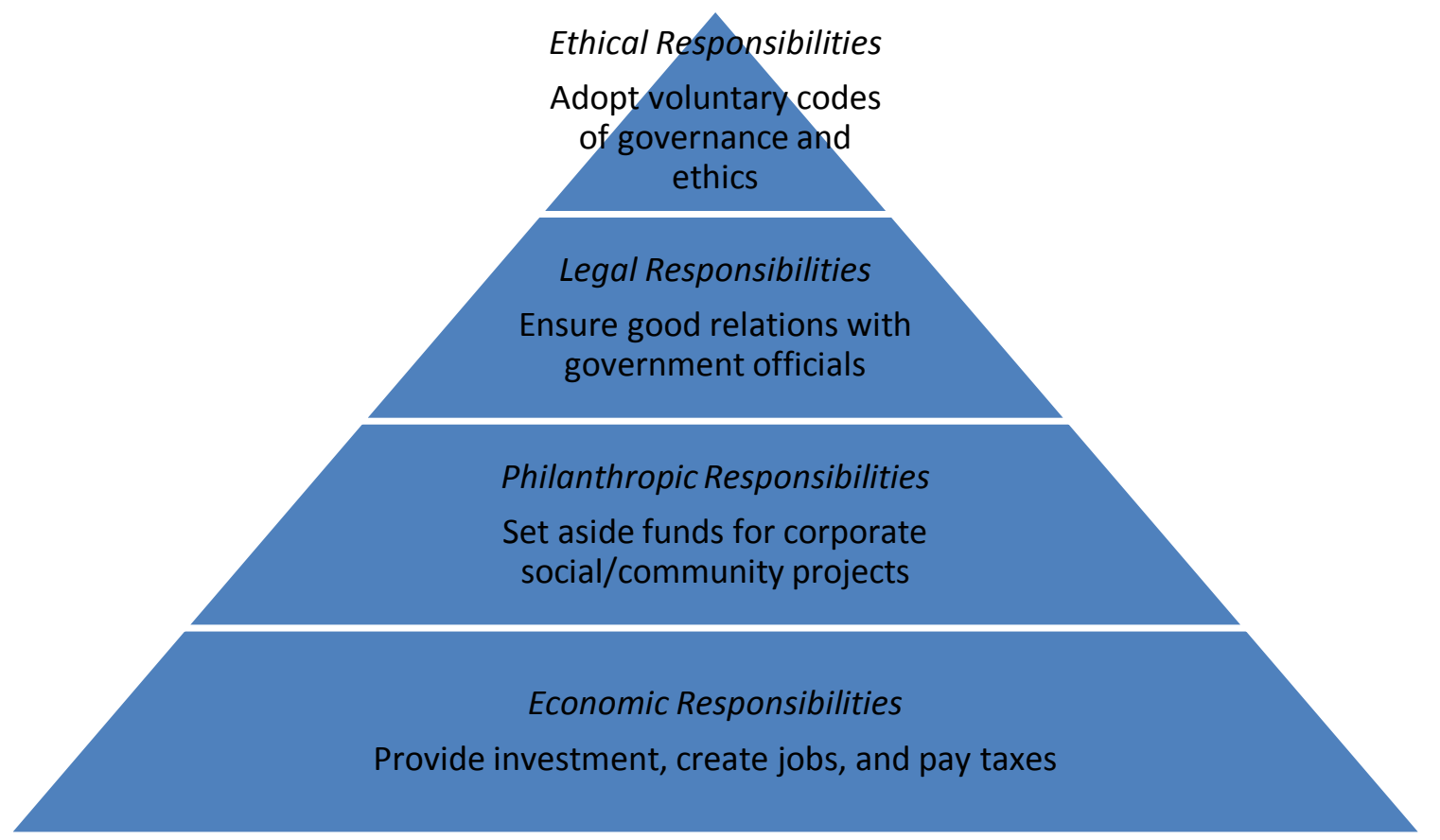

Source: Yakovleva et al (2008)

They both agree that the most important aspect is economic responsibilities. Carroll and Visser however, differ on what comes next and where philanthropy is placed in the whole spectrum. The bottom line is to be profitable, pay taxes and create employment. This is in line with Friedman's (1962, cited in Wall 2008) theory that the only goal of companies is to make a profit and everything else, including social responsibility, is secondary. Even though there is no single way in which companies can fit either compartment, it is worth noting that research has been done to explore how best to incorporate CSR in profit making companies given it is not their core business.

Some companies operate CSR as a public relations and marketing tool to increase profits through the positive public image that can be generated by CSR programmes. It also satisfies the economic and legal requirements; it allows companies to obey the law and pay taxes. Usunier et al. (2011) claim that according to this perspective, sacrificing some profits to finance expenses associated with social responsibility makes sense because this contributes to a good and more acceptable corporate image of the company. They further argue that a better corporate image will in turn lead to increased profit. Gilberthorpe and Banks (2011) argue that capitalism is destructive and extractive because corporations take resources from the 
community. Kakabadse and Morsing (2006) affirm that "CSR generates an alternative to the negative and destructive perception of capitalism, that in capitalism anything is permissible, after all it's just a business out to make a profit" (p. 10). Wall (2008) suggests that it is due to this "proper selfishness" companies such as Ben and Jerry, Timberland Shoes and the Indian Tobacco Company enjoyed superior stock market results when they took a proactive CSR approach in the 1990s (p. 7). In this way, CSR can be viewed merely as a platform to give capitalism a human face.

Some authors agree however, that CSR is synonymous with philanthropy. Wall (2011) states that, CSR is going beyond charity and philanthropy as companies take on responsibility for their environmental and social impact. In addition, other philanthropists go beyond sustainable development and engage in large scale projects. For example, the Bill and Melinda Gates Foundation are involved in health, HIV, and education projects mostly in subSaharan Africa (Bill \& Melinda Gates Foundation, 2013), Nike gives shirts, cardigans and sports shoes to people in Zambia (we received large consignments when I was working for World Vision), and Fonterra gives milk to children in low decile schools in New Zealand (Fonterra, 2013).

Sustainability is an important aspect in development processes. Kakabadse and Kakabadse (2007) explain that CSR is synonymous with sustainable development. Allouche (2006) stresses that "CSR is about ethical issues where companies feel responsible for the welfare of their neighbours, in this case the welfare of people in communities where they operate" (p. 4). Garvey and Newell (2005) elaborate on this point when they explain that CSR should pay more attention to corporate accountability to the poor through state, corporation and community related factors. Lungu and Mulenga (2005) state that the central issues to CSR are: accountability, local economic development, community involvement, the environment, ethics, governance and human rights. These may be prioritized differently by different corporations but they encapsulate the wider spectrum of CSR. Therefore, in summary, CSR has been viewed on a continuum as Carroll's analysis shows, from profit oriented to philanthropy. I would argue that most companies implement CSR within this continuum with some being very profit oriented, others more inclined to help genuinely and others in between. I would also like to note the continuum is also fluid because perceptions and policies change in companies as well as in communities. This is just one way in which I have 
decided to explain CSR from perspectives of different authors and practices of different companies.

\subsection{CSR Practices, perspectives and key debates}

Given the magnitude of the impacts of mining, most companies often get involved in CSR. Whether this is a public relations stunt or they genuinely want to help is hard to determine. I believe that CSR with all its imperfections is still valuable for the community because as an old saying goes, 'half a loaf of bread is better than none'. Mining companies have different ways of implementing CSR. In Argentina communities expect mining companies, amongst other things, to: protect natural environment and comply with environmental regulations; uphold high standards of health and safety; contribute to sustainable development and generate alternative economic development; contribute to local community development; develop local infrastructure such as school, libraries and museums; and improve the wellbeing and quality of life and provide employment (Yakovleva et al p. 6). In Papua New Guinea, an independent development foundation was formed in 2007 to deliver development projects such as; telecommunications towers, road networks, rural electrification agriculture development, microfinance facilities among others, on behalf of the Oki Tedi mine (Gilberthorpe, 2013).

I argue that CSR should be more than a once-off charitable event meant for ticking the box. It should actually address issues of sustainability in a way that the mining company leaves lasting positive change in the community, especially so for mining because minerals are not available underground forever but are a non-renewable resource. Jenkins (2005, cited in Idemudia, 2011) argues that mainstream CSR suffers from selective amnesia because issues such as tax avoidance, unsustainable investment and poverty reduction do not appear on the agenda. For this reason, I am suspicious of the real intention of CSR in the extractive sector such as mining, because by nature the industry removes so much from the earth in terms of it being a spatial location and from the community in terms of livelihood. For example, Kiikpoye (2012) states that Oil Transnational Companies (Shell and Chevron) in the Niger Delta in Nigeria, engage in diesel powered electricity for rural communities who are too poor to buy diesel, when solar or gas turbines would be more sustainable. In my view CSR is being implemented but it does not meet the needs of the people in the Niger Delta. In fact it exacerbates the volatile security and poverty situations. Carmody (2011) describes overall 
operations of ExxonMobil in Niger Delta as being responsible for devastation of local communities and vegetation due to oil spills and an increase in the number of people killed each year due to conflict. However in a bid to make CSR more responsive to needs of local people, Chevron has recently announced changes in the way they will carry out CSR activities. Chevron took a novel hybrid approach, establishing the Niger Delta Partnership Initiative as a semi-independent development organization with deep local roots. The NDPI, through its on-the-ground implementing agency, works to find market-based solutions to local economic problems. Chevron launched the NDPI Foundation, a US-based non-profit organisation, in 2010 with an initial grant of \$50 million (Devex Impact Editor, 2013). Chevron employees make up a minority of the organization's independent board. NDPI's implementing agency is the Nigerian Foundation for Partnership Initiatives in the Niger Delta, known as PIND, a Nigerian-registered nonprofit that has its own board of development experts (Devex Impact Editor, 2013). I am hopeful that even though the negative impact far outweighs any 'good deeds', CSR can contribute to change, for the betterment of livelihoods in Niger Delta.

Employment and business opportunities are also considered as a sustainable way of implementing CSR. I agree with Visser et al. (2007) who argues that CSR is about community development which includes recruitment, purchasing and investment decisions in order to bring about prosperous local communities. This is in line with the local recruitment policy of Barrick Gold and FQM in Solwezi who try to ensure that local people are considered for full time jobs in their mines qualifications and education levels notwithstanding. Visser et al. (2007) further explains that CSR is a form of good corporate citizenship which means extending the relationship between business and society to include social, political and environmental responsibilities of a business. Bendell (2005) suggests that CSR should mitigate environmental degradation and worker abuse, engaging in social development and ensuring fair trade through the corporate supply chain. CSR should therefore address the issues that the people in the area of operation see as important to them. It should be implemented in the best interest of people, the employees, families of employees and the community as a whole. CSR is a balanced progress on economic development, environmental quality and social justice (Elkington, 1997, in Haalboom, 2012). This is akin to Cramer's (2006) assertion that companies should find a balance between people (social well-being), planet (ecological quality) and profit (economic prosperity). If CSR fails to address these issues then it becomes tokenism and a waste of resources and effort. So far, the 
literature reviewed in CSR says little about the community's voices and the perspectives of local people towards CSR efforts.

This is in contrast to Gildan, a Montreal based marketer and manufacturer of apparel with factories in Central America and the Caribbean. Gildan invests in its human resources by creating local opportunities for team members to attain higher education, training and development. The CEO of Gildan is an active proponent of the Polytechnic Institute in Honduras which his organization is a lead funder, (Wall, 2008). Can Gentile, one of the executive vice-presidents of Gildan state that:

We need to have a major advantage over our competitors and key to this is welltrained motivated staff. Some companies look at CSR as costing money, we see it at reducing costs because it contributes to having well-trained, focused and committed employees, (Wall 2008, pp 78-79).

The CSR approach of Gildan appears to be more introspective in terms of focusing on the company's profits, but nonetheless it is an acknowledgment of the importance of CSR. Another advocate for CSR is John Thornton ${ }^{2}$ of Barrick Gold. One local staff member, Silver, said that when he visited Lumwana mine in Solwezi, he said:

If you aspire to be a world class mine then your CSR programme should be world class. If you have needs on operations and community where will you spend your money? It is a wise thing to spend money on operations to increase profit but after some time when you discover you need to increase the radius where the power line should pass and you go to the community to ask for land do you think they will give you the permission to pass the line through their village? There should always be options of working with the community. The mine and the community are interdependent. Mutual collaboration is necessary for growth, (Interview from this case study, $23^{\text {rd }}$ May 2013).

From this statement above, it is clear that CSR plays a key role in community engagement at Barrick Gold. CSR is a means of supporting the community, creating alliances and building relationships. But, CSR is also about protecting the company's interest to ensure it can run its business smoothly. A good public image is good for the business in Zambia and abroad.

Glasenburg, CEO of Glencore also expresses the need for more investment in education and health in their operation areas. He states that developing countries need more investment and

\footnotetext{
${ }^{2}$ John Thornton is being mentored by Peter Munk to take over as Barrick CEO when Munk retires. He visited Lumwana sometime early in 2013 .
} 
not less because investment provides jobs, education, health care, and infrastructure (BBC, Why Poverty Documentary, 2012). CSR may be interpreted differently by different corporations but the general consensus focuses on investing in people, whether those working in the corporations or those in the host community.

\subsection{Key debates on CSR}

Many corporations have embarked on including CSR in their reporting mechanisms. In this section I discuss the key debates concerning CSR. Firstly, some authors argue that this is a bid to show that what they are doing really makes a difference in improving people's lives. Ontiveros (1986) states that there is a growing trend towards increased disclosure of CSR programmes by management in various corporations. She further adds that having a concern for CSR is seen as good management within a corporation. Even though this is the case, there is still scepticism especially amongst scholars and bureaucrats in sub-Saharan Africa. For example, Okonjo (2012) is wary of corporate philanthropists who are doing community work in the health sector in Africa, without the collaboration of government officials. Her argument is that they may not really care for the people or may not have identified the real needs in the communities but they want to portray an image of caring and thus spend money. Without collaboration with governments in developing countries and local people, CSR may not yield the intended results of sustainable development.

Secondly, some scholars also view multi-national corporations from developed countries as insensitive to the needs of people in the sub-Saharan Africa. Idemudia (2011) argues that CSR falls short of addressing the real needs and aspirations of host communities and governments. In my opinion, if companies fully embrace the views and aspiration of the host community and the government especially the government department responsible for the particular social issue such as education, health or agriculture, implementation can be more successful. Idemudia (2011) argues that the role of corporations in the pursuit of sustainable development should take into account South-centered CSR where aspirations and views of the people in the global South take precedence during decision making. This is in line with postdevelopment theory with regards to challenging power imbalances. Emphasizing the need to include beneficiaries in decision making contributes to their empowerment. It also detracts from perceived superiority of experts and foreigners and waters-down their ability to 
dictate what development interventions should be implemented. This is also the aim of feminist approaches employed in this thesis.

Thirdly, Frynas (2005, as cited in Idemudia, 2011) further argues that the CSR agenda has largely been driven by Northern actors and has inadvertently diverted attention away from addressing the real political, economic and social problems facing people in developing countries. Kiikpoye (2012) states that CSR is not just a means of addressing negative externalities generated by a business in its engagement with stakeholders but is also a tool for international development and in turn for poverty reduction in developing countries. Because in many developing countries the government is struggling to provide sufficient social services, such as in Zambia, assistance from the private sector can be useful source of funding. CSR implementation is often on the premise that society expects corporations to provide safe and meaningful jobs, safeguard the environment and provide charitable donations (Lungu \& Mulenga 2005). Mining is the biggest industry in Zambia and therefore the contribution through CSR is arguably beneficial, especially for rural communities because they have fewer services than those in urban areas.

In conclusion to the CSR debate, there is a need to explore whether CSR can be an effective additional funding source for social services at both the macro and micro level. Banks (2008) states "in Papua New Guinea the community has meetings with mining investors before exploration and they set their social needs and the mining companies meet these needs as a requirement before beginning mining in an area" (p. 23). This could be useful in the implementation of CSR in other countries. Lindgreen and Swaen (2010) suggest that there is a need for interdisciplinary research on CSR implementation to validate its usefulness. Based on research in PNG, Banks and Gilberthorpe (2011) argue that extractive industries are exploitative and unsustainable in nature because they extract non-renewable resources from the countries in which they operate and they give little in return. It is for this reason that I think CSR is necessary, whatever the motivation, so that at the least the host community can gain some form of benefit albeit meagre.

In light of the above discussion and research gaps, this research investigates CSR from the perspectives of local community members and Ministry of Education officers to explore how the initiatives are contributing to access to education and development at the community level. The literature reviewed has shown that little has been documented on local people's 
and Ministry of Education officers' perspectives on CSR in Zambia. Are there real, tangible benefits as opposed to unreal and intangible ones according to the perspective of the local community? There appears to be little or no collaboration between the corporations and government departments responsible for providing the social services in Zambia or more generally around sub-Saharan Africa. This accentuates the assertion of Western hegemony and uneven power relations, because Western corporations can appear to have quite a lot of influence in the communities of the countries they operate in. This hegemony supports Idemudia's (2012) claim that CSR may not yield the intended results because corporations have minimal collaboration with government departments and communities thereby making CSR projects non-responsive to the needs and aspirations of the local people and they are not sustainable in the long run. It would be better to increase the capacity of the government that will remain after the mining company has depleted the copper and left.

\subsection{Privatisation and CSR in Zambia}

The Zambian mining sector has undergone various phases as stipulated in the previous chapter. During the time that the mines where owned by the Anglo American Corporation and Roan Selection Trust, employment conditions essentially provided housing, education, health, water and recreation for those who worked in the mines (Lungu 2008). During the years of nationalization there was a more pronounced 'cradle to the grave' welfarist approach. In this current privatisation dispensation, social issues have taken a different twist in that it is not mandatory to provide such welfare facilities (Lungu 2008). This is because private investors need to make a profit and there is a limit to how much they can spend on such programmes. CSR has become a way of giving back to the community and it is more pronounced during times when copper prices are high and the profits are lucrative. However, CSR is voluntary and the mining companies are not obliged by law or any other policy framework to implement it. The CEO of the Luanshya Mine was quoted by Fraser and Lungu and presents it clearly when he states that spending too much money on community support would undermine profitability, both of the company and their long term ability to deliver economic development in the region (Fraser \& Lungu 2007). This shows that his primary goal is to make profits and bring economic development to the area, in line with Friedman's (1962) argument that the focus on social responsibility of corporates is to make a profit. There is one and only one social responsibility of business: to use its resources and engage in activities designed to increase its profits, so long as it engages in open and free competition 
without deception or fraud (Friedman 1962, cited in Wall 2008). The logic behind this kind of thinking is to create increased profit and contribute to the economy on the assumption that as this happens, there will be more benefit to the community through more jobs, more taxes for the government's use and more economic boom.

Currently all the mines in Zambia are owned by private companies. Some are entirely privately owned, and others have the government as a minority shareholder. In this situation, the new owners may have a different approach to the welfare of the communities in which they operate. Lungu (2008) states that health and education were among the social services provided by ZCCM for all mine workers, their families and other people in the communities, however today fees apply to use these facilities and such fees are usually prohibitive. At present, privately-owned companies are more focused on efficiency and profits, because they bought or acquired the mines at a price, and they need to generate profits for the shareholders. It is worth noting that the literature reviewed has revealed many differences in the way different investors view CSR. There was also an expectation from the various communities were mines operate, that the new mine owner would continue the social programmes that the government had during the Nationalisation era. Many of the expected benefits of privatisation for the local economy have not materialised for the original Copperbelt province as well and the New Copperbelt, as the linkages made by new mine owners are to suppliers, manufacturers and markets outside Zambia.

Fraser and Larmer (2010) state that the new mine owners of all mines that were privatised were hesitant to take on the non-core activities that the mines were engaged in previously. Many local suppliers have lost the business they used to have with Zambia Consolidated Copper Mines, the shareholding company of mining on behalf of the government, for a range of reasons but mainly because they are unable to compete on quality and price with foreign suppliers. Fraser and Lungu (2007) state:

Although the Zambian Government frequently raises this issue, it seems either unwilling or unable to enforce on the mining companies a system of constraints and incentives that would make up not just a mining policy, or an investment policy, but an industrial policy designed to support local suppliers and to build a local manufacturing base processing copper in Zambia (p.4).

For example, it seems clear that several mining companies do not wish to support local businesses and will seek foreign suppliers. To cushion this situation, I believe CSR can be a 
vehicle not only for poverty reduction but for wealth creation as well, if a holistic bottom-up approach can be employed.

CSR can be viewed as a type of development aid, as suggested above, because funding is made available to provide public goods such as education, health and water supply, yet it is also linked to dependency, trade and profits. Furthermore, in order to explore how the private sector can be an alternative funding source for increased social services and delivery of development projects, it is imperative to understand the extent to which private companies involve the host communities in project planning and implementation. Thus, even if the company does not directly trade with local businesses, they need to connect with the community before implementing any form of CSR. This will foster sustainability in the long term even after the mining companies leave.

\subsection{Education and CSR in Zambia}

This thesis looks at education CSR projects in Zambia's mining sector. There is a link between mining and education because mining companies provide access to education through CSR projects. The other link is through taxes and other payments to the government and in turn the government spends on education through the public coffers. The Zambian government spends 3.3 percent of public funding on education (Human Development Report 2012). For this reason of low expenditure in education, I agree with De Haan's (2007) suggestion that there is a need to integrate economic and social policy within the publicprivate sector nexus. In this suggestion he details how this integration can increase public expenditure to key sectors such as education and health. Loxley (2013) also suggests the need to take advantage of the public-private partnerships in which the government and public sector can work together, especially on infrastructure projects.

From my observations there is a great need for education, especially in rural areas in Zambia. The mining industry is the highest single contributor to Zambia's GDP and foreign exchange earnings. Because of this situation, the contribution of mining companies to Zambia's social services is vital, not just through tax revenue but through CSR. Although all of the five major mining companies in Zambia conduct CRS activities, this research will explore a case study of Barrick Gold's CSR projects. Barrick Gold has a highest per capita investment in Zambia and therefore it provides a good case study because of its size. While Barrick Gold undertakes several CSR activities such as education, health, agriculture and women's 
microcredit clubs, this case study only focuses on education. This is because increased schooling leads to better quality of life, lower infant and maternal mortality as well as increase in income especially for those who are able to access formal employment. It also contributes to gender and racial equality especially with policies such as girl child education which is an integral part of Zambia's education policy and local employment policy which is one of the issues that the chiefs in Solwezi have been advocating for with the two mining companies that are based there.

Modern education (formal schooling) is one of the key drivers of economic development in any society. Although I appreciate that traditional education such as Ujaama, a traditional approach to learning such as weaving, hunting, gathering and communal leaving values are preferred to education formal schooling by some people, such an education will not necessarily guarantee empowerment and emancipation. This is because for many jobs whether formal or otherwise, arithmetic and English competency are not only a necessity but a must. It is common in Zambia and many other countries in Africa, to place English proficiency as a 'must have' for any job advertised. In fact, English is an inevitable requirement for tertiary education in Zambia. This is even more so in developed countries. I recall when I made my application to undertake this Masters' programme at Victoria University, I had to prove my English proficiency before I could be given an offer. Barro (1997 cited in De Haan, 2007) argues that education is a critical determinant of economic progress because greater educational attainment means more skilled and productive workers, a higher output of goods and services and easier absorption of new technology.

Not being able to read and write in English augments exclusion and people are cut off from the global system. Sharpe (2009) suggests that in order to be heard, to be listened to and taken seriously others must also adopt Western thought, reasoning and language. Resisting the language and Western ways of knowing exacerbates exclusion and Western hegemony. Sharpe (2009) further explains that this was clearly expressed during colonisation when European languages of colonisers (especially English and French in sub-Saharan Africa) were favoured over local languages. For much of Anglophone Africa, including Zambia, English was and still is, necessary for anyone to achieve any form of employment or business. In order to curb exclusion, Western hegemony and poverty, the Rest have to come to the West and be able to use their talents and capabilities to their own advantage instead of remaining in a position of vulnerability and exploitation. In this way they will be able to 
challenge the status quo and seek better alternatives. How else can Zambian government officials negotiate prices, taxes or even loans with investors, IMF or World Bank if they cannot read and write or argue in the international arena of politics and finance which is carried out in English?

Globalization and economic significance (due to mineral deposits) will connect the people of Solwezi to the rest of the world. Owing to this, education is necessary for people to be able to assume agency and to be heard. Sen (2000) affirms the development process is one that expands people's choices and freedoms, and contributes to removal of unfreedom such as poverty, tyranny, negligence and intolerance. Sen (2000) further states that education is a key to freedom, choice and values. Education is an important driver for development, both human and economic, it is one of the ways that people can gain access to permanent employment and other economic opportunities (Moyo 2009). More importantly, education goes beyond economic empowerment but also contributes to agency and social movement. Loluave (2011) argues that the aims of education either by general or vocational training is for people to earn their own living to fulfil needs and wants of human beings. Therefore I strongly believe education is a significant issue for the people of the North-western province of Zambia if they are to achieve emancipation from poverty and push their way out of deprivation. I am aware that this will not be a quick fix solution to a complex problem but it is a start nevertheless.

Low levels of education in North-western province in general and Solwezi in particular has been a hindrance for locals in securing full-time jobs in the mines (Alstine \& Afionis, 2013). Due to recent discoveries of oil and gas and the opening up of two mines (Alstine \& Afionis, ibid), the demand and need for education in North-western province has increased, and the local people want a fair share of employment in the mines, necessitating such education. A parallel can be drawn between the expatriates who came to work in the Copperbelt in the late 1920s. As few Zambian's were educated from the inception of mines in the late 1920s until the early-1970s the people who currently work in the mines come from other parts of the country because few natives of the area are educated. Therefore the need for formal schooling is high. Rahnema and Bawtree (1997) suggest that the school system was introduced by colonialism and it became the most important vehicle for development. It was presented to people excluded from mainstream development processes as the answer to all their problems of underdevelopment. But the exclusion has increased and due to its scarcity more people are trying their best to ensure their children access to education because of this perceived benefit. 
Education is the only way that poor people can access a better livelihood in terms of jobs and financial freedom (Moyo, 2009). Access to education in North-western province as a whole and Solwezi in particular has been inadequate. In my view this is a gap the CSR programmes being implemented by Barrick Gold is trying to fill. As to whether it is helpful to the local community, is a matter that this research asks. I further discuss the issue in chapter five, the findings chapter.

\subsection{Conclusion}

From a postdevelopment perspective, it is no longer morally right for the companies to pay the low royalty and company taxes when the situation has changed for the better and they are enjoying high profitability. Companies should not continue paying workers poverty wages and denying them community welfare services when they are enjoying excellent profits. The provision of community welfare services in the mining industry evolved because of the mining companies' failure to provide a living wage. As long as the wages remain at subsistence level, it is necessary to resuscitate the programmes in community welfare to make natural resource exploitation less exploitative of labour. This is, however, the simpler shortterm solution to the country's complex developmental problems for which service delivery is just one strand. Barrick Gold and Glencore consider the community to be a strategic partner and forging amicable alliances with them is vital. I am aware that this raises the public relations versus genuine philanthropy debate but nonetheless the two companies' officials recognize the importance of CSR, despite its short comings in reality.

From the literature reviewed, it can be deduced that little study has been done on the perceptions of local people and mining staff towards CSR especially in Zambia. The community in Solwezi has great expectations but in most cases these are only partially fulfilled or unfulfilled altogether. The lack of clarity over the definition of CSR and how it should be implemented poses a challenge in that each corporation does as they see fit. This often means that programs are short term and tied into the fluctuations of the global market prices for minerals. Consequences of this have been grave in that the community has not benefitted as much as they should have, and they are left to deal with the negative effects of the extractive industry. This chapter has dealt with the second research question and traces the history, current debate and practice of CSR globally and in Zambia. It is hoped that no matter where Barrick Gold fits on Carroll's pyramid in Figure 4.1 of the economic 
responsibilities-philanthropic continuum, perspectives and opinions from local people and the Ministry of Education can influence company CSR policy to enhance benefits for the local people. I believe that if the CSR resources are well regulated and utilized, the extractive industry can leave a lasting legacy in these communities through well-planned and implemented sustainable development programmes. This will take a lot of negotiation and a paradigm shift, because for the most part, CSR still has a top-down approach and there is no single form of implementation. Against this backdrop of complexity of CSR, this research taking and postdevelopment and feminist approach sought the opinions of the people involved to determine whether reality meets their expectations. The following chapter discusses stakeholders' perspectives on CSR. It also discusses CSR as an aid modality and explores policy options within this framework. 


\section{CHAPTER FIVE \\ Findings and Analysis}

"Development is not development until it can impact positively on people's lives."

(Uranium, Interview $7^{\text {th }}$ May, 2013)

\subsection{Introduction}

This chapter discusses the findings of the case study. It draws on the perspectives of the local people, government and mining company officials with regards to CSR in education by Barrick Gold in the Solwezi district. In my analysis, I have summarised their aspirations, gratitude, frustrations and satisfaction with CSR implementation, taking into account both the processes and outcomes. As stated in the methodology chapter, the thesis is anchored in broader discourse of postdevelopment using feminist philosophical approaches. Accordingly, this thesis brings the perspectives of local people to the forefront. I am mindful of the politics of representation as argued by Palomino-Schalscha (2011) but I intend to bring the voices of the people of Solwezi as a contribution to reduce exclusion, marginalisation and poverty. I interviewed teachers and school managers from two schools, two staff from the Ministry of Education and the chief of the local area. I also had a focus group discussion with people from one of the communities in Solwezi. All interview participants are referred to using pseudonyms and explained in Chapter two.

\subsection{Research Questions}

This research specifically looked at CSR activities undertaken by mining companies. The research investigated one company and its education interventions. The aim was to explore how the local people in the host community and the Ministry of Education officers perceive mining and corporate social responsibility. This chapter answers questions three to five of the thesis which are:

3. How do people in the Solwezi community perceive Barrick Gold's CSR education programmes in terms of benefits and shortfalls?

4. How do officers from the Ministry of Education at district level view Barrick Gold's work in the education sector?

5. Can CSR become a form of aid modality for development programmes? 
The private sector is a potential source of funding that communities and governments could utilize for development projects. Iwaela (2012) states that in the near future the private sector may provide more funding for development projects than the traditional Official Development Assistance (ODA) provided by multi and bilateral donors. The research aimed to explore the interaction between the government department responsible for providing education services and the mining company. This thesis explores if and how CSR can provide viable funding approaches to facilitate access to education in Zambia. It is motivated by the need for Africa to find alternative models for community development and CSR is just one resource that can be a contributor to sustainable community projects that may enhance human development especially for the excluded and rural poor. Gilberthorpe (2013) states that "the increase in global demand for fuel and non-fuel minerals has seen an expansion of extractive industries in low and middle- income countries and this has coincided with increased scrutiny by academics and conservationists" (p. 467). Hence this primary research is in addition to other research in academia about the benefits of extractive industries in low-income countries like Zambia.

\subsection{Barrick Gold and CSR in Solwezi}

Barrick Gold is a transnational mining firm with mining activities in many countries in the world. It is owned by Canadians who bought Lumwana mine from Equinox Mining. Barrick Gold undertakes CSR activities based on its community engagement strategy. Copper, a participant working at Barrick Gold explained that the company has a CSR strategy, community engagement strategy, a community relations and community engagement plan as guiding documents for CSR implementation. Copper explained that these documents are international documents but adapted to each site based on context (Interview, 7 May 2013). Despite this adaptation of documents to the local context, Uranium the chief of the village, perceives Barrick Gold as a big Western company extracting from the community and giving little to the community (Interview, $7^{\text {th }}$ May 2013). He said "Barrick Gold is a big international company and I expect them to do more in terms of CSR than Equinox did."

Barrick Gold implements CSR in three chiefdoms of the Solwezi district; Mukumbi, Matebo and Mumena chiefdoms see Figure 5.1. The chiefdoms are traditional boundaries under the chief's jurisdiction akin to an Iwi in New Zealand. Solwezi has a total of seven chiefdoms and the fieldwork was conducted within one of the chiefdom's in Solwezi. Establishing mines 
in this area could not be possible without the consent of the chiefs who hold the 'title deeds' (even though these are not physical documents) of the land. Negi (2010) explains that in order to operate in the area, Barrick Gold had to develop close relationships with the three Kaonde chiefs within whose chiefdoms the mine area overlaps. "I cannot allow anyone to loot my minerals without ploughing back into my community," (one of the chiefs cited in Negi 2010, p. 209). In my observation this is a strong case for CSR as a way in which Barrick Gold can indeed plough back into the community. Even though this other chief from a different chiefdom states this, the traditional leaders have little power to overturn contractual agreements negotiated and signed between TNCs and central government.

\section{Figure 5.1}

Map of Chiefdoms in Solwezi district

The white on the centre shows the area of the mine.

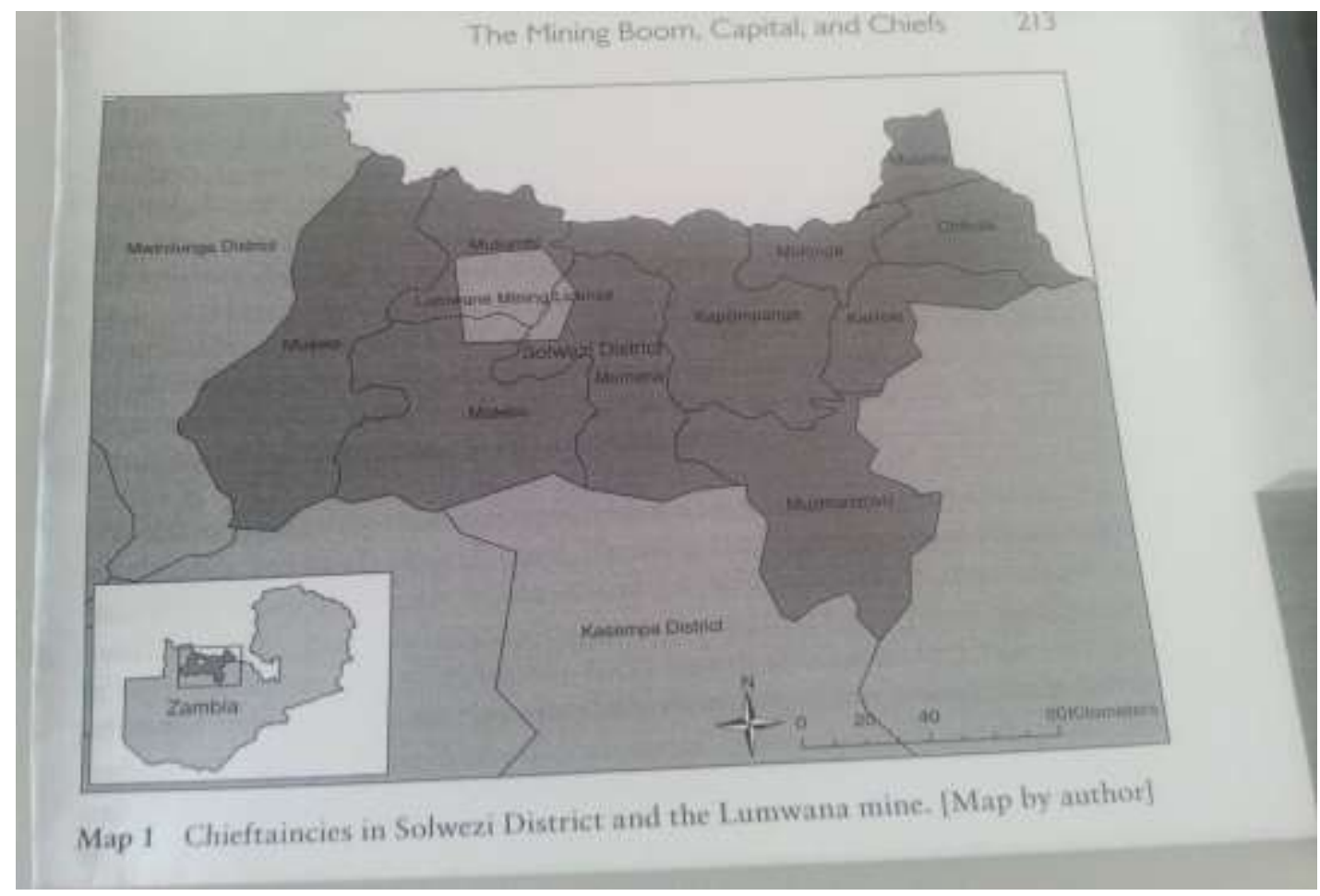

Source: Negi (2010)

\subsection{Barrick Gold's engagement with the Solwezi community and government}

Community voices are essential in this thesis because I sought to hear perspectives from the community on CSR and education. It is also inevitable as a commendable practice in development projects in that community participation and engagement should be the basis of community projects so as to avoid designing and implementing projects with little or no correlation to the needs of the people for whom the projects are intended. Therefore the views and aspirations of beneficiaries should be considered when planning and implementing 
interventions. In order for CSR to be responsive to needs and aspirations of the people in the community, companies must negotiate between meeting the needs and demands of all their stakeholders (investors, host governments, employees, and local communities) and aim to create shared value for their shareholders and society (Wall, 2008). There is growing literature on the contextualization and relevance of CSR to the particular issues in a country or community. Cramer (2006) states that, company CSR policy should take socio-cultural context and social needs and problems into consideration. She adds that for South Africa, Black empowerment and the fight against HIV and AIDS are of cardinal importance and these may not be the socio-cultural or social needs and problems in other countries. Local cultural and social context is of cardinal important to addressing local issues and community participation and engagement is the best way to do this. As Maconachie and Hilson (2013) observe, "how community actors perceive and respond to extractive industry investment plays an important role in shaping how companies fashion their business strategies and CSR agendas" ( p. 351).

From this field research, I believe that with community and other wider stakeholder engagement, Barrick Gold has the potential to implement CSR in such a way that it makes a real difference in the community and the district. In addition, each mine in Zambia may be confronted with different issues based on the district or city it is operating in and therefore it is necessary for each mining company to create and implement a CSR policy that will yield optimal results for the area in which they operate. As Idemudia (2012) suggests:

In order for CSR to achieve its full emancipatory potential, the bottom-up approach to CSR analysis needs to increasingly become more dominant. The studies on CSR bottom-up approach are still in the minority. More needs to be done to better understand CSR's impact on society as opposed to CSR impact on business and beneficiaries perceptions and experiences of CSR must become central to the analysis (p. 13).

Figure 5.2 shows the hierarchy in the Zambian government and in the traditional setting with regard to authority. The Minister of Education is the custodian of education policy and delivery at central government level, followed by the provincial education officer and then the District Education Board Secretary (DEBS). The DEBS is the person in charge of education at district level and has the ability to make decisions as fit for the district. In the traditional setting the chief is regarded as very important. This is most obvious in rural setting 
such as Solwezi. The royal establishment comprises of different people from within the chief's family and a few elderly people from other clans. The royal establishment is also highly regarded by the chief because they usually have meetings to decide on matters pertaining to the chiefdom. This is a mesh of hierarchies that do not make power relations easy even within Solwezi or any other district in Zambia. But the Western hegemonic system of corporate entities contributes to the power struggle to an already complex situation of authority.

\section{Figure 5.2}

Hierarchies of authority in Zambia in the Ministry of Education and in the traditional setting

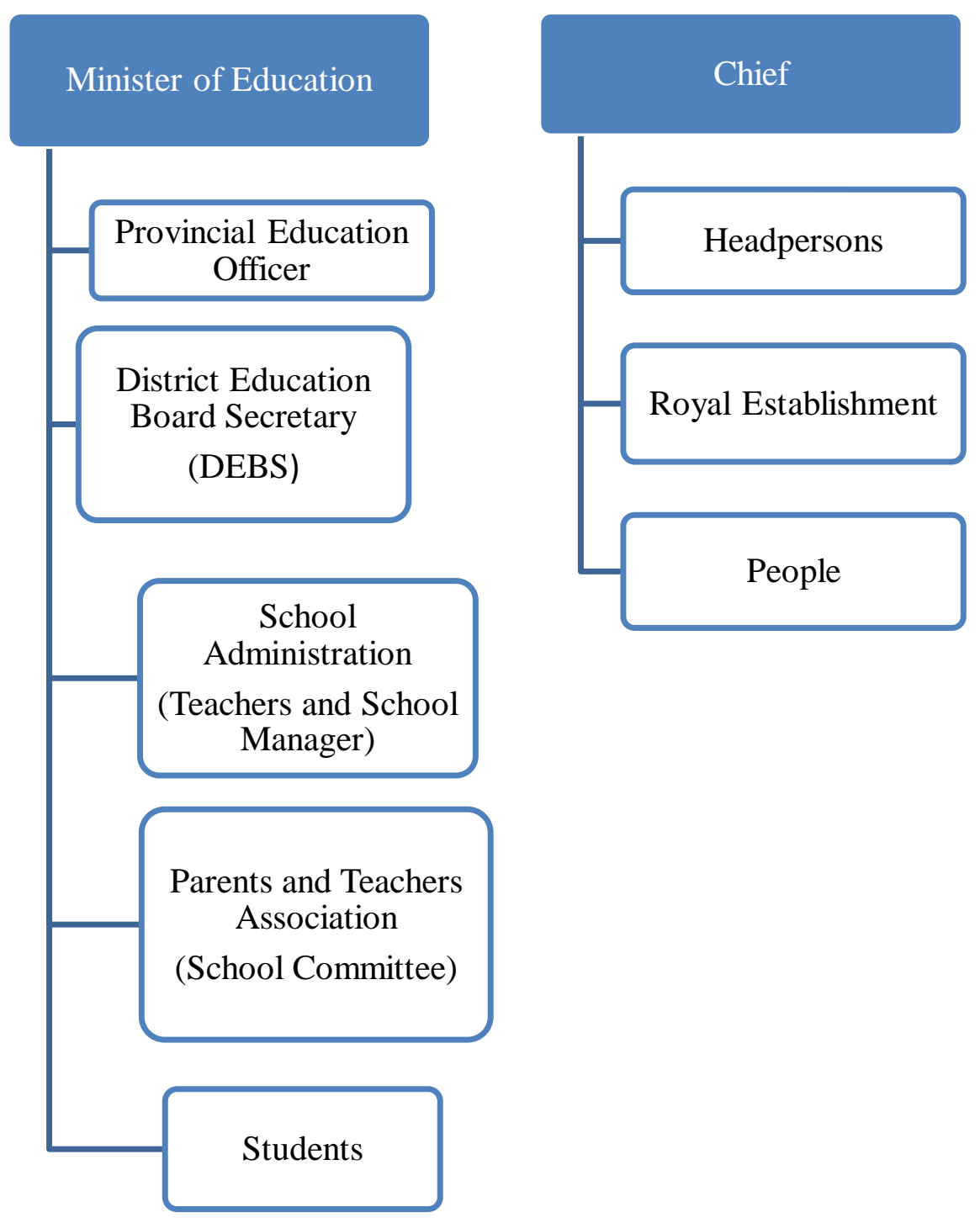

Source: Womba Mayondi (2013)

It is important to note that consultative meetings are held by Barrick Gold with the community, the Ministry of Education and schools before CSR activities are done. These are 
quarterly meetings and they provide an opportunity for the local people to express their needs on project implementation. The staff members from Barrick Gold's sustainability department identified various educational needs and are assisting the community to acquire much of the required assistance. The people in Lumwana community communicate with Barrick Gold through the meetings that the mines hold at the school. One of the male parents explained that "there is usually interaction between parents and teachers through meetings" (Focus Group Discussion held 8 May 2013). The following extract from an interview with Gold, a school manager from school A, illustrates this communication:

Community and schools jointly submit requests to Barrick Gold tabulating the projects they want funding for. Needs assessments are jointly done by Barrick Gold staff members, representatives from the royal establishments from each of the chiefs and the Community Land Use Planning and Development Committee. The composition of this committee is representative of all parts of the chiefdom which includes parents and teachers. The committee submissions assist the staff from the Sustainability Department to adapt their CSR strategy to the needs and aspirations of the community (interview $6^{\text {th }}$ May 2013).

In addition, Zinc, from the Ministry of Education, also explained that funding for projects is given directly to the school (Interview $8^{\text {th }}$ May 2013). This was confirmed by Cobalt, another officer from the Ministry of Education, who explained that the Ministry of Education is informed of the funding and supervises construction works because all construction projects have to be approved by Ministry of Education for standard and quality (Interview, $8^{\text {th }}$ May 2013). This is a commendable action because the people in the community identify what projects need to be undertaken and they suggest them to the sustainability manager of Barrick Gold. However, they do not always get what they ask for and many times they need to negotiate. Gold explained that "they are currently waiting for funding to commence construction of a school block based on earlier negotiations" (interview $6^{\text {th }}$ May 2013). This is much better than if Barrick Gold staff implement projects without input from the community. Cobalt, from the Ministry of Education, also explained that the relationship between their office and Barrick Gold has improved and it is amicable, although in the past staff from Barrick Gold would just implement projects directly with the schools without informing his office. This was difficult as any education project in the district should be approved by the Ministry of Education because education is the responsibility of the Ministry. 
The Ministry of Education recognizes the need to cooperate with other partners in order to increase access to education. To this effect the Ministry of Education policy encourages and seeks to strengthen partnerships with private and voluntary agencies in provision of education through co-operation, coordination and planning with other stakeholders (Ministry of Education, 1996).

There is better communication between Barrick Gold and the Ministry of Education than it was in the past. However, in terms of mutual accountability, Cobalt explained that they never obtain written reports from Barrick Gold's Sustainability Department of the education projects they are implementing but they are orally informed of what is being done during District Development Coordinating Committee (DDCC) meetings, or meetings held between their office and Barrick Gold (Interview $8^{\text {th }}$ May 2013). DDCC meetings are formal meetings held quarterly and they are convened by the Mayor who is the most senior government officer in the district. They are convened for the sole purpose of development reporting and representatives attend from various government ministries at district level, non-governmental organizations and the private sector. These meetings are a government standard and they happen in all districts around the country. Cobalt stated that the increased consultation has improved outcomes, especially during construction projects. However, more joint planning between Barrick Gold, the Ministry of Education and the school would be helpful to the people of Solwezi to attain more benefits.

Barrick Gold also takes a community participation approach to CSR, where the community is viewed as a strategic partner essential to the operations of the mine. Copper, from Barrick Gold explained that,

A cordial relationship between the mine and the community is important for better project implementation. The department in charge of CSR at Barrick Gold is called the sustainability or community relations department. Consultations are held between Barrick, Royal Establishment Representatives from the three Chiefdoms and representatives from the Parents Teachers Associations from various schools.

...During the consultations, different stakeholders express their views on what projects should be done. They then submit a joint proposal which stipulates the projects they want Barrick Gold to fund (Interview, 7 May 2013). 
When community needs are presented to Barrick Gold they carry out an assessment themselves, and then they fund projects according to their priorities and strategic objectives. Information is shared at the DDCC meetings. The District Education Board Secretary (DEBS) who oversees all education programmes at district level shares plans in education and funding needs. DEBS gets requests from schools and after making further consultations they submit these requests to the mine. Apart from communication through DDCC the school interacts directly with staff at Barrick Gold (Interview with Gold and Silver held 6 May 2013).

Ideally, there should be constant communication and exchange of information between all parties. This could be with any partner and any ministry and this is what local government (district administration) recommends. In practice this is subject to debate, but in my experience that is what development workers would do during projects. The interviewees stated that there is some form of consultation between Barrick Gold and the stakeholders, and development programmes are influenced by these consultations. However, the ability for the community to have their voices heard, regardless of the amount of so-called consultation, is weak in Zambia compared to other countries. For example, the community's power in influencing the local government in Esquel, Argentina is much stronger. Walter and Martinez-Alier (2011) state that local communities in Esquel opposed mining due to the magnitude of environmental damage that open-pit mining causes. In this case, the Esquel community were strongly mobilised and empowered, and worked with a local university to devise a local community development plan, which became a benchmark for all transnational companies establishing mines in Esquel.

Although the community empowerment in Zambia is not as established or mobilised as this, the fact that opportunities for consultations exist and the community somewhat has a platform to air their views is helpful for the community and shows the potential for communities to have some influence over decisions made about projects to be implemented or at least become more empowered. Although the Ministry of Education, the chief and the community do influence how Barrick Gold implements projects, they do not appear to have veto power over what and how projects are done to the level that the people in Esquel have. The power relations favour Barrick Gold's opinions because by the time they establish the mine, have had a series of negotiations with the central government. This alters the power dynamics of 
all involved and in the end the community members and Ministry of Education in Solwezi would still have to succumb to whatever Barrick Gold decides.

Since Barrick Gold took over the mine when they bought it from Equinox (who were the first owners of Lumwana mine then sold it Barrick Gold), it remains to be seen what more the company can do for the improvements of living standards of the people. Barrick Gold should not continue implementing CSR at the same size as Equinox did as they should increase their investment in the province. Since there is no funding coming from central government for capital items, Barrick should increase their funding to make the community better (Interview with Uranium held on $6^{\text {th }}$ May 2013).

The people in the community expect more investment in CSR programmes because they have an idea to a certain extent of how much copper is exported. They also know that the more tonnage of copper leaves their community, the more profit the company makes, external factors such as prices notwithstanding. Therefore the expectation is high.

\subsection{Benefits of CSR in Solwezi}

Despite limitations in community participation in Barrick Gold decision making, research participants recognised a number of benefits they derive from Barrick Gold CSR education projects. These are listed below.

\section{- Infrastructure}

Infrastructure is a critical need in Solwezi. Infrastructure needs identified by the people and teachers are teachers' accommodation, classroom blocks and latrines (usually Ventilated Improved Pit Latrines (VIP) which are different from waterborne toilets). The interview with Uranium revealed that there are only 10 high schools in the whole of North-western province and much fewer in Solwezi district. This puts people of Solwezi at a disadvantage compared to people from other parts of Zambia. Cobalt explained that 'teachers' houses that have been built in various schools so far are a motivation to retain teachers because many of them leave the school due to a lack of accommodation. Both teacher training and construction of teachers' accommodation is intended to increase student performance" (Interview, 6 May 2013). Figures 5.4 and 5.5 show some buildings which have been completed. There are also new classroom blocks completed, as shown in Figure 5.6. Amber explained that "the school has enjoyed several benefits, including a diesel powered water pump for the school garden 
and three teachers' houses. Barrick Gold paid the electricity supply company for the connection of electricity and the school, which was previously rural with no electricity, now has electricity. The construction of infrastructure has led to an increase in enrolment" (Interview with Amber, teacher $9^{\text {th }}$ May 2013). Copper also stressed that "a high school class has graduated after sitting national examinations in December 2012". This is an improvement in access to education because these children would not have attained this education without the increased infrastructure and buildings provided by Barrick Gold’s CSR.

\section{Figure 5.3}

Picture of Teacher's make-shift accommodation School B

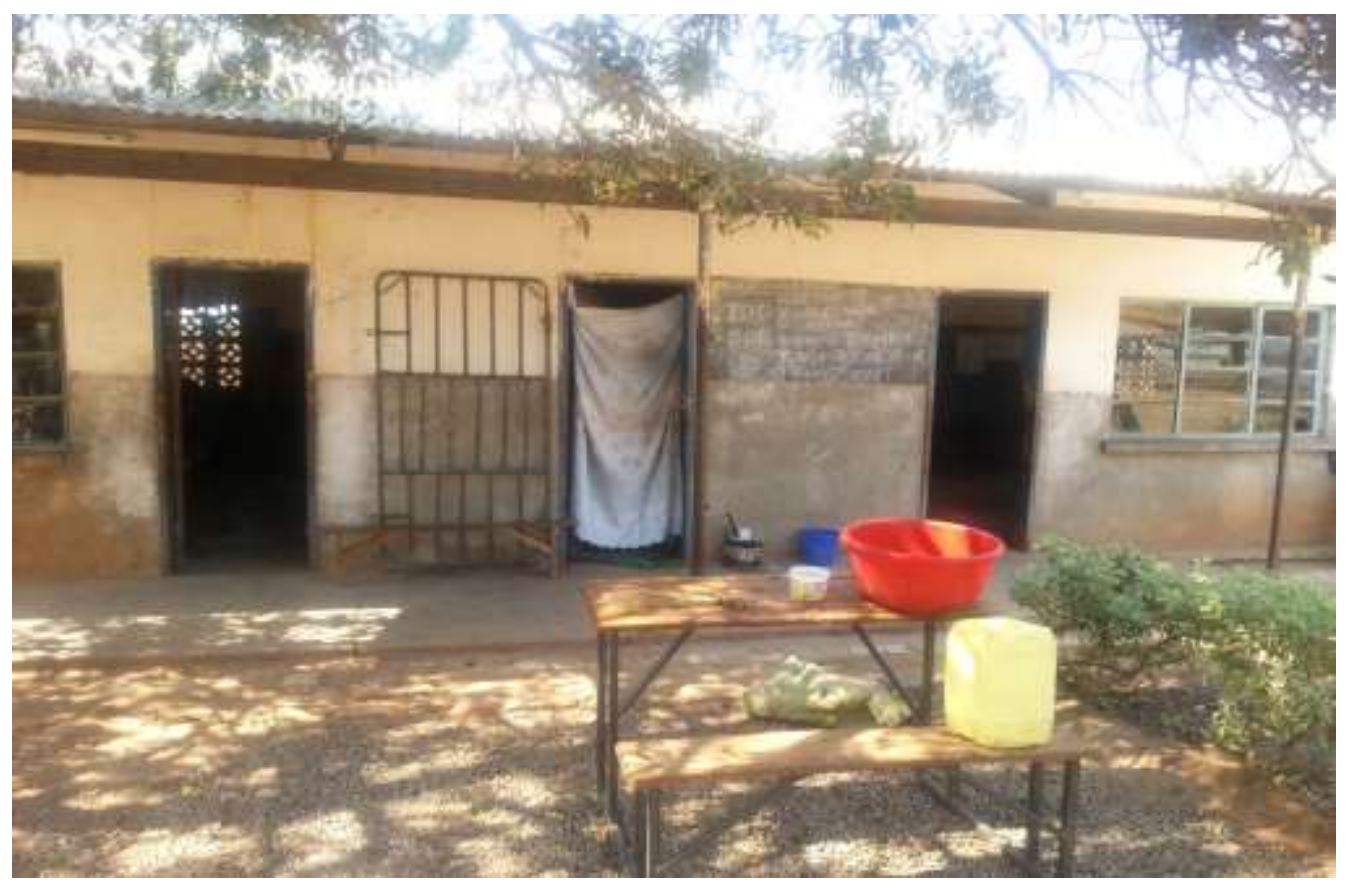

Source: Womba Mayondi, $5^{\text {th }}$ May 2013 


\section{Figure 5.4}

Newly constructed teacher's house. This is a standard house for a teacher based on specifications from Ministry of Education-School A

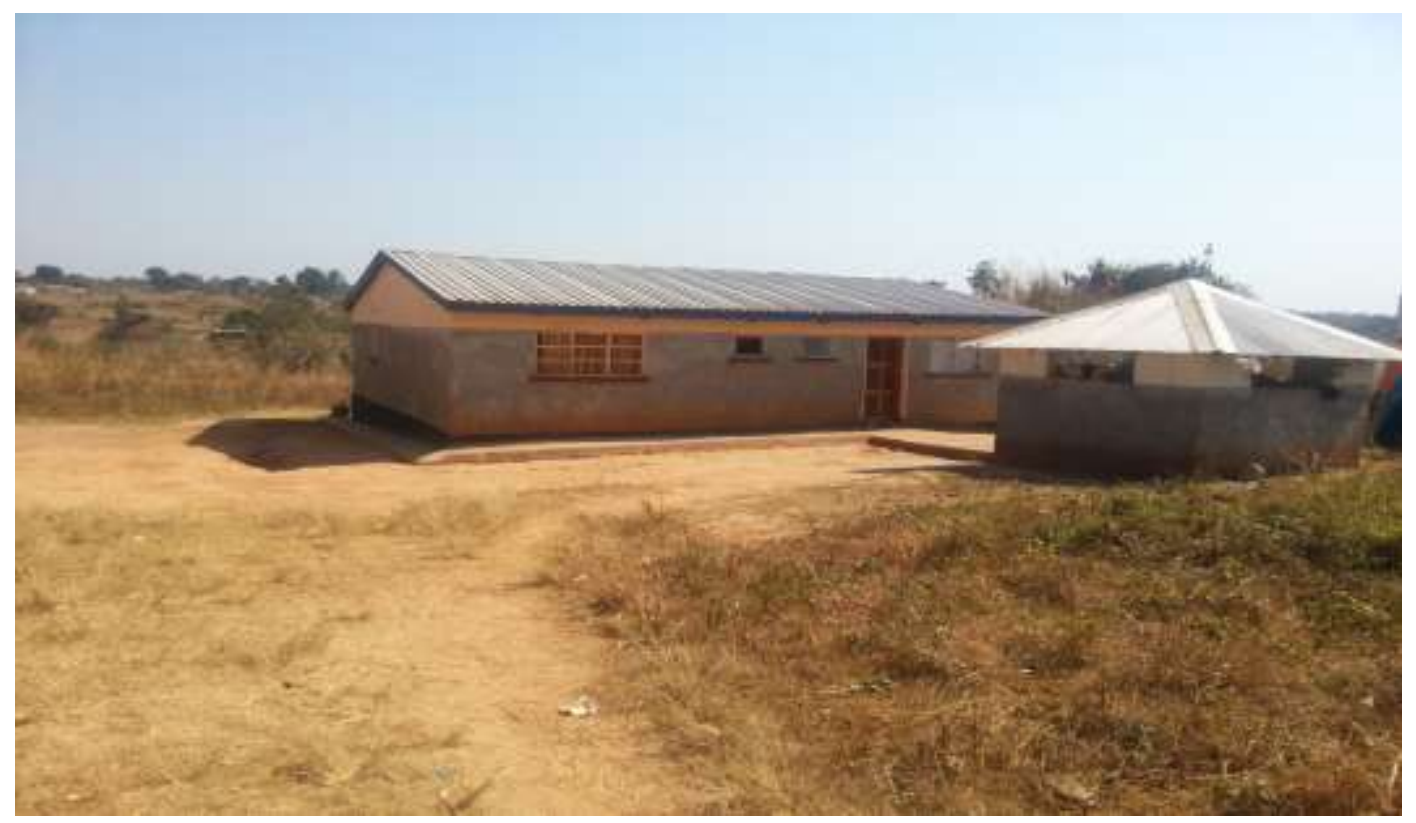

Source: Womba Mayondi, $5^{\text {th }}$ May 2013

\section{Figure 5.5 Classroom Block}

One of the recently completed classroom blocks in Solwezi constructed with funding from Barrick School A

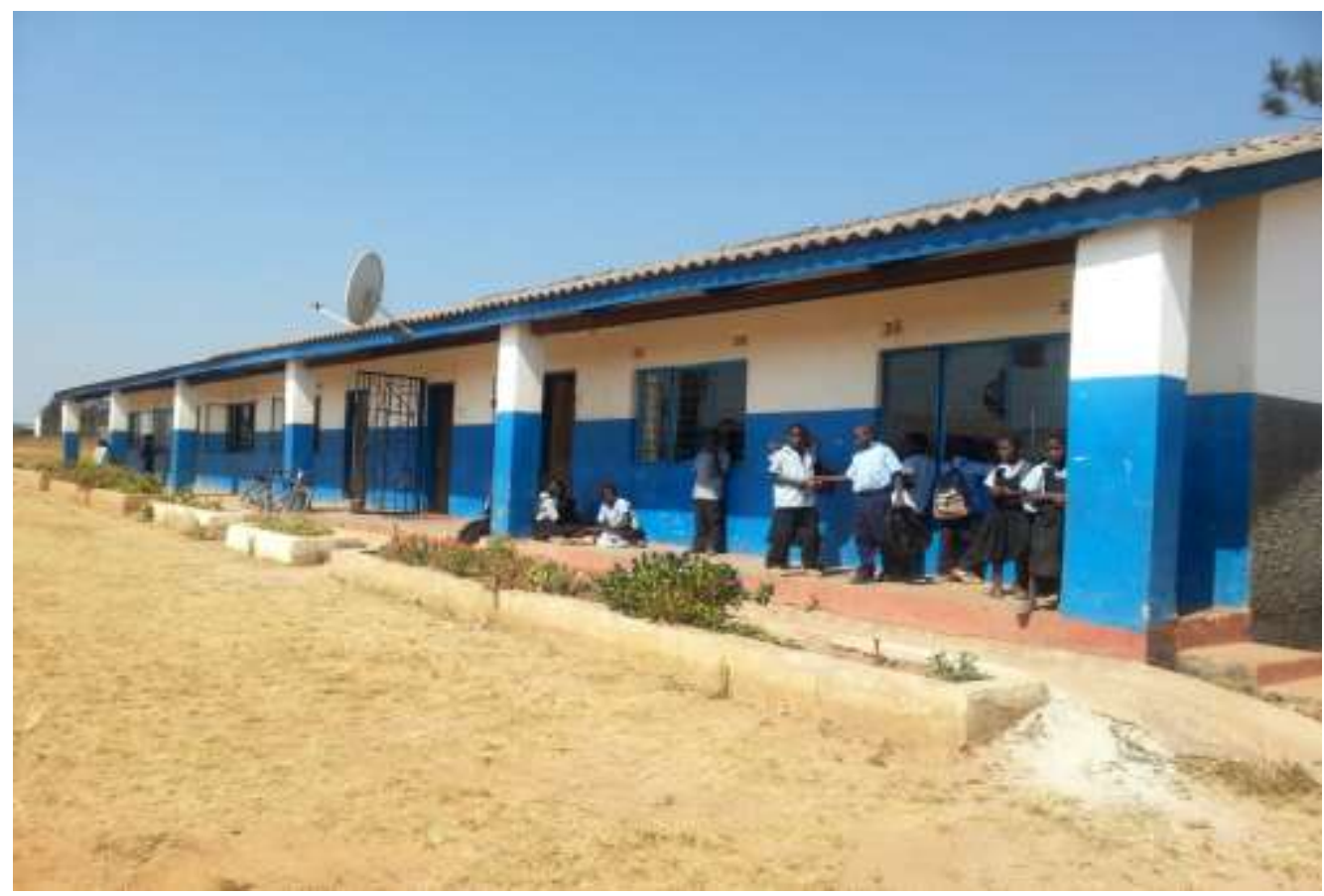

Source: Womba Mayondi $8^{\text {th }}$ May 2013 
The report obtained from Barrick Gold shows that since 2009 to date, the company has implemented 15 construction projects ranging from schools, teachers houses, laboratories and libraries in Solwezi. Approximately US \$597,229 has been spent on these projects (Barrick Gold, 2013). They have also constructed infrastructure at other school in neighbouring Kasempa district. Another 18 construction projects have been planned for the next phase.

\section{Figure 5.6}

List of education projects undertaken from 2009 to date.

\begin{tabular}{|c|c|c|c|c|c|c|}
\hline $\mathbf{s} / \mathbf{n}$ & $\begin{array}{l}\text { Name of } \\
\text { LDTF } \\
\text { project }\end{array}$ & $\begin{array}{l}\text { Descripti } \\
\text { on }\end{array}$ & Status & $\begin{array}{l}\text { Budget } \\
\text { (ZMW) }\end{array}$ & Actual Spend & $\begin{array}{l}\text { Budget } \\
\text { Variance }\end{array}$ \\
\hline 1 & $\begin{array}{l}\text { Mukumbi } \\
\text { Basic School }\end{array}$ & $\begin{array}{l}5 \text { Staff } \\
\text { houses }\end{array}$ & $\begin{array}{l}4 \\
\text { complete, } \\
1 \text { Roofing }\end{array}$ & $355,198.75$ & $387,646.08$ & $32,447,33$ \\
\hline 2 & $\begin{array}{l}\text { Jiundu } \\
\text { Secondary } \\
\text { School }\end{array}$ & $\begin{array}{l}1 \times 3 \\
\text { classroom } \\
\text { block }\end{array}$ & Complete & $200,000.00$ & $223,571.01$. & $23,571.01$ \\
\hline 3 & $\begin{array}{l}\text { Lubinga Basic } \\
\text { School }\end{array}$ & $\begin{array}{l}1 \times 3 \\
\text { classroom } \\
\text { block }\end{array}$ & Complete & $215,000.00$ & $190,678.98$. & $-24,321.02$ \\
\hline 4 & $\begin{array}{l}\text { Luamvundu } \\
\text { Basic School }\end{array}$ & $\begin{array}{l}3 \text { Staff } \\
\text { houses }\end{array}$ & Complete & $239,000.00$ & $217,226.02$ & $-21,773.98$ \\
\hline 5 & $\begin{array}{ll}\text { Shinda } & \text { Basic } \\
\text { School } & \end{array}$ & $\begin{array}{l}1 \times 3 \\
\text { classroom } \\
\text { block }\end{array}$ & Complete & $210,000.00$ & $160,392.13$ & $-49,607.88$ \\
\hline 6 & $\begin{array}{l}\text { Manyama } \\
\text { Basic School }\end{array}$ & $\begin{array}{l}1 \times 3 \\
\text { classroom } \\
\text { block }\end{array}$ & $\begin{array}{l}\text { Finishing } \\
\text { works }\end{array}$ & $200,000.00$ & $396,930.26$ & $196,930.26$ \\
\hline 7 & $\begin{array}{l}\text { Kananga } \\
\text { Basic School } \\
\end{array}$ & $\begin{array}{l}3 \text { Staff } \\
\text { houses }\end{array}$ & Complete & $220,000.00$ & $443,701.25$ & $223,701.25$ \\
\hline 8 & $\begin{array}{l}\text { Kambazhi } \\
\text { Basic School }\end{array}$ & $\begin{array}{l}2 \text { Staff } \\
\text { houses }\end{array}$ & Complete & $110,000.00$ & $239,661.91$ & $129,661.91$ \\
\hline 9 & $\begin{array}{l}\text { Mwajimambwe } \\
\text { Basic School }\end{array}$ & $\begin{array}{l}3 \text { Staff } \\
\text { houses }\end{array}$ & Complete & $241,117.25$ & $209,748.26$ & $-31,368.99$ \\
\hline 10 & $\begin{array}{l}\text { Mutanda High } \\
\text { School }\end{array}$ & $\begin{array}{l}1 \text { Science } \\
\text { Laboratory }\end{array}$ & Roofing & $385,000.00$ & $414,494.27$ & $29,494.27$ \\
\hline 11 & $\begin{array}{l}\text { Meheba High } \\
\text { School }\end{array}$ & $\begin{array}{l}1 \text { Science } \\
\text { Laboratory }\end{array}$ & Roofing & $350,000.00$ & $533,555.79$ & $183,555.79$ \\
\hline 12 & $\begin{array}{l}\text { Kamano Basic } \\
\text { School }\end{array}$ & $\begin{array}{l}1 \times 3 \\
\text { classroom } \\
\text { block }\end{array}$ & Complete & $200,000.00$ & $226,597.43$ & $26,597.43$ \\
\hline 13 & $\begin{array}{l}\text { Muyashi Basic } \\
\text { School }\end{array}$ & $\begin{array}{l}1 \times 3 \\
\text { classroom } \\
\text { block }\end{array}$ & Complete & $204,113,00$ & $214,148.61$ & $10,035.61$ \\
\hline 14 & $\begin{array}{l}\text { Lunsala Basic } \\
\text { School }\end{array}$ & $\begin{array}{l}3 \text { Staff } \\
\text { houses }\end{array}$ & Complete & $240,000.00$ & $227,905.82$ & $-12,094.18$ \\
\hline 15 & $\begin{array}{l}\text { Kyansununu } \\
\text { School }\end{array}$ & $\begin{array}{l}1 \times 3 \\
\text { Classroom } \\
\text { Block }\end{array}$ & $\begin{array}{l}\text { Not yet } \\
\text { commenc } \\
\text { ed }\end{array}$ & $240,000.00$ & - & - \\
\hline & Total ZMW & & & $3,165,316$ & $3,672,008$ & 506,692 \\
\hline & Total US \$ & & & 597,229 & 692,832 & 95,602 \\
\hline
\end{tabular}

Source: Barrick Gold, Sustainability Department (2013) 
Table 5.6 shows the total number of schools that Barrick Gold has supported in Solwezi district only from the time they took over the mine (2009) to 2013. The rate is \$US 1 to Zambian Kwacha (ZMW) 5.30.

\section{* Sponsorships and donations}

Education in Zambia is free from grade one until grade seven. A small levy is charged by the school for some administrative costs but no school fees are required in public schools until grade seven. From grade eight to twelve the fees are relatively high and many students cannot afford them. Since parents need to pay school fees, which range between (ZMK 300 an equivalent of US \$60 to ZMK 500 an equivalent of US \$100 per term), high school education is a luxury for most children. Many parents cannot afford to pay this money, and hence, parents appreciate the scholarships. Barrick Gold gives scholarships to students which comprise of schools fees, books and uniforms. The scholarship scheme starts from grade 10. . The report further states that more than 363 pupils have been offered scholarships for High School (grade 10-12) since the scholarship scheme begun in 2009 (Barrick Gold 2013). Cobalt suggested that "the scholarship scheme is highly motivating for the students because more girls and boys are aspiring to get good grades so that they can be given a scholarship." (Interview held on $6^{\text {th }}$ May 2013). Attendance has improved because the children are aiming for sponsorship (Interview Jade a teacher, on $9^{\text {th }}$ May 2013). Amethyst, a male teacher, confirmed that pupils now have school uniforms, which they received from the mine as a donation. At school A, 15 students are sponsored, however there are a lot more needy children (Interview, $8^{\text {th }}$ May 2013). One mother explained that if a child is very intelligent they receive assistance in the form of sponsorship which lasts as long as they continue to do well. She added that the sponsorship helps some children complete high school and they can even be sponsored up to tertiary education. Another parent stated that the sponsorship is helpful because children receive school fees and school uniforms (Focus Group held on $8^{\text {th }}$ May 2013). Barrick Gold suggested that only students with high marks from the national exam in grade nine would be selected for sponsorship. In my view, it is worth noting CSR has contributed to increased access to education even though we cannot fully trace how significant the increment is in terms of figures, it is an acknowledgement nonetheless.

The other problem is that there is only one Teachers' Training College in Solwezi. The college offers primary teachers' training certificate. For this reason, there are very few teachers in Solwezi and many of them have only gone up to certificate level and only a few 
have diplomas and degrees. As another kind of scholarship scheme, Barrick Gold gives scholarships to teachers to upgrade their credentials and they can go and study further at universities or colleges in other cities in Zambia. Jade, a female teacher, explained that Barrick Gold by providing monetary support for teachers to upgrade their credentials is helpful (Interview, $9^{\text {th }}$ May 2013). Silver confirmed this and also added that teachers with diplomas are pursuing degrees and those with certificates are pursuing diploma programmes (Interview, $8^{\text {th }}$ May 2013).

\section{* Gender Issues}

In Zambia, particularly in rural areas, many families prefer to send their boys to school while girls stay home to do house chores. This was very common in patriarchal communities such as Solwezi, on the basis that the boy would marry and needs to be educated to support a family, while girls would be supported by the men who will marry them. This is another form of oppression that many African girls and women grapple with. However this is slowly changing because of the women's movement in Zambia that has been advocating for equal rights with public awareness campaigns in rural areas where this practice was very rampant. It is worth noting that attitudes towards girls' and women's education are changing at all levels across the country. The women's movement's main catch phrase has been "if you educate a man you educate a person if you educate a woman you educate a nation." The premise for this catch phrase was that women are primary care givers and if they are educated they will more likely ensure their children are also educated and they are likely to use their resources towards the access to education and health for of their children. Kabeer (2005) states that research in Kenya found that women with at least four years of schooling were able to correctly understand instructions for administering oral rehydration salts and in Nigeria educated women were more likely to know about family planning and understand disease and prevention. Even though education in general and schooling in particular has been criticised to be Western and a form of continued imperialism, I think the opposite (being illiterate) is worse. This Kabeer's argument validates the importance of women's education.

In Solwezi, there has been an increase in girls attending school because of scholarships and increased infrastructures. The other reason is that of the women's movement which has vigorously campaigned for equality in education for girls and boys. Gold, Cobalt, Amber and Jade all explained that there has been an improvement in the disparities between girls and boys attending school and that there are more girls accessing education now than they were 
before, because more girls are being given an opportunity to attend school. (Interviews on $8^{\text {th }}$ $\& 7^{\text {th }}$ May 2013). Amethyst explained that although in higher grades from grade six onwards some girls drop out of school due to early marriage the situation is slowly changing and there are more girls attending school now. Figure 5.7 shows the numbers of boys and girls at the two local schools in this case study, and it is noted that School A now has more girls than boys. In school B there are more boys than girls but the gap has been reduced because the number of girls has increased due to sponsorship of students according to Jade and Amber (Interview, $9^{\text {th }}$ May 2013).

\section{Figure 5.7}

Data on gender distribution for schools in this case study

School A and B

\begin{tabular}{|l|l|l|}
\hline & School A & School B \\
\hline Boys & 389 & 263 \\
\hline Girls & 402 & 251 \\
\hline Total & 791 & 514 \\
\hline
\end{tabular}

Source: School Records 2013 enrolment.

\section{* Furniture and teaching aids}

Furniture in terms of school tables and chairs for both pupils and teachers are in short supply in many schools. Education facilities are not only inadequate in rural areas but also illequipped. Therefore, there is dire need for more furniture in the schools. Barrick Gold bought curtains for classrooms and offices, desks for students and stationery for the school. The schools also received teaching material donations such as text books (Interviews with Amber and Jade held on $9^{\text {th }}$ May 2013).

Work attitude among teachers has also improved due to increased furniture and teaching aids (Interview with Amber on $9^{\text {th }}$ May 2013). For Jade the situation was very different before as she explained: "Previously we had few teaching aids and the furniture was not enough". In my observation, this donation of furniture and teaching aids helps improve the schooling environment, which shows that Barrick Gold is contributing to local education in a beneficial way that meets a local need. 


\subsection{What needs to be improved?}

The participants had several suggestions concerning what needs to be done in order to improve the situation. Their suggestions pertain to access to education in terms of increased facilities and improvement in livelihood in terms of clubs so that they can generate income to pay for the school requisites for their children.

\section{* Education and infrastructure}

Uranium also added that there should be more sponsorship for children in tertiary education such as those at the Solwezi Trades School. A number of participants suggested that Barrick Gold should consider building a university because there are few tertiary institutions in the district. More buildings in terms of teacher accommodation and classroom blocks were also suggested. Amber and Jade, as well as some parents during the focus groups discussion, suggested that there is currently over enrolment in schools due to inadequate infrastructure, therefore more infrastructure would be a great benefit to the students.

The inadequate central government support was noted by one participant. "Much of the money from central government comes from Solwezi by virtue of having two large mines in the district. Even though this is the case there is not much infrastructure development in terms of classroom blocks, teachers' houses and latrines funded by central government hence the mine should consider increasing their support" (Interview with Cobalt held on $6^{\text {th }}$ May 2013).

Participants acknowledged that there is need for more latrines, teachers' houses, classroom blocks and a clinic. They want Barrick Gold to consider funding an upgrade of the school with more infrastructure. They also suggested that scholarships should start from grade eight onwards not only from grade ten as parents need to pay from grade eight. As well as more fully fledged boarding schools should be built they also suggested that a university should be built. The school is under-staffed because of inadequate housing for teachers. Finally, they mentioned that there should be a gender balance especially with regards to scholarships (Focus Group Discussion held on 8 May 2013).

CSR is not backed by any legislation in Zambia, it is only a moral obligation. The law is silent on CSR. There is no regulatory framework that can ensure the host community receives optimal benefits. The investor decides what they want to do and how much they can invest. Choices from the community are limited due to lack of exposure. For example requests for 
water facilities are limited to boreholes with a hand pump. There is no request for advanced water reticulation systems.

Related to this comparison is another suggestion to do with the uneven nature in which programmes are implemented. Jade a female teacher explained that:

Some schools are benefitting more than others. More teachers' accommodation and classroom blocks are required. Sometimes a classroom has 70-80 students and this makes teaching and learning very difficult. The maximum according to the Ministry of Education standard should be 45 students. But there are more pupils in the classes due to the shortage of teachers in schools where the teacher's accommodation is limited, as well as a shortage of classrooms (Interview Jade held on 9 May 2013).

Clearly Barrick Gold cannot provide funding all at once, but there is need to draw up a sustainable strategic plan of action which can be shared with Ministry of Education, and subsequently school managers, teachers and parents. This will help to remove the perception that some schools and thus communities are benefitting more than others.

\section{* Income generating activities}

Parents also made other suggestions pertaining to needs for Income Generating Activities (IGAs) that would assist them financially. They noted that these occurred in other CSR projects in other parts of Solwezi.

Barrick Gold should also consider supporting a women's club which can assist the elderly and the orphans. Women's clubs such as poultry, vegetable and legumes garden, tailoring, nutrition or a carpentry workshop can be an IGA to assist the orphans and elderly in the community. Other communities have benefitted from IGAs that is what we want. They have dairy cows which were supplied to female youths. The women's club was also given funding to build a large multi-purpose hall and they hold meetings in it. Another woman's group is rearing chickens which they sell to the general public (Focus Group Discussion held on $8^{\text {th }}$ May 2013).

\footnotetext{
Advocacy

Participants also explained that Barrick Gold should support behaviour change sensitization because other negative effects such as drunkenness, prostitution and theft have increased since the opening of the mine (Interview, $6^{\text {th }}$ May 2013). Although many children are in school there are still many others who succumb to early marriages for financial reasons and
} 
anti-social behaviour. Such children and their parents should be targeted with Behaviour Change and Communication (BCC) programmes so that they can change their attitudes (Interview Uranium 7 May 2013). Advocacy is seen as helpful because children, youth and parents will see the importance of education and opt to stay in school than indulge in other negative behaviour.

\section{* Exposure and sports for students}

One of the suggestions was that Barrick should fund some sporting activities for children. Cobalt, from the Ministry of Education, suggested that Barrick should put up interschool sports competitions and school trips to different places so that the students can be exposed to different things and that they should also support peer to peer teacher training (Interview $6^{\text {th }}$ May 2013). In addition, Uranium suggested that pupils should have a field trip to Barrick Gold and see people working in various fields because this will motivate them to work extra hard and aspire for greater things (Interview $7^{\text {th }}$ May 2013).

\section{Accountability and transparency}

Mutual accountability would be possible if Barrick Gold shares information with the community and the Ministry of Education. Cobalt mentioned that the relationship between their office and Barrick Gold is cordial but more systematic communication is desirable to meaningfully address the community needs. Zinc also explained that "the Ministry of Education rarely receive formal written reports from Barrick Gold on the education projects being implemented" (Interview, $6^{\text {th }}$ May 2013). In my view, better formal communication would foster joint planning and joint implementation and thereby contribute to quality project outcomes.

\section{* Summary of general trends and practices}

The community, school administration and Ministry of Education all have different views on the benefits of CSR, what Barrick is doing well and areas for improvement. This research, through interviewing the local community directly affected by Barrick Gold's CSR, found many positive benefits as well as some areas for concern. The need for education is high because it raises the prospects of acquiring jobs in the mine for the locals. For this reason, the need for Barrick to invest more in education cannot be ignored. However, in my analysis of the participants' responses, some of the requests and suggestions may be beyond the company's own perceived role or vision for CSR, and these items should be negotiated or fulfilled by either local or central government. Overall, Barrick Gold's contribution in the 
education sector is highly appreciated, looking at what the people have said, however, there is a need to increase coverage so that more children can access education. The key area of consensus among participants is that more infrastructure should be built. Without more educational infrastructure, such as teacher accommodation, education is hampered.

The community members also cited the need for other facilities such as a medical clinic, and aspirations for other facilities such as a tertiary institution and income generating activities. The government may need to revisit the development agreement in the Mining and Minerals Act 2008 to include CSR or other social services, and negotiate if Barrick Gold should also fund such facilities. Suffice to state that in other communities' IGAs are being done but this was not the case in this situation where the case study was done. There seems to be mutual accountability between Barrick, the community and the Ministry of Education, but there is no official document to bind such accountability or reporting. This is also an important finding this lack of official documentation. Even more, it is not easy to determine the extent to which the perceptions from the community and indeed from the Ministry of Education influence Barrick Gold's internal policy decisions about CSR projects.

There are more boys and girls able to access school as a result of the CSR work Barrick is doing. The consultation with community and government also shows that, to a certain extent, Barrick implements activities in line with the aspirations and needs of the community. This concurs with Amethyst's statement that the mine should continue with the assistance and should increase the number of children being sponsored (Interview $8^{\text {th }}$ May 2013). These statements highlight the fact that the people do not have enough money to pay for their children's school requisites, and thus they are reliant on sponsorship.

Further, this will contribute positively to the development of Solwezi both human and otherwise. Cowen and Shenton (1996) state that characteristics for intentional development are deliberate, externally driven, strategic, economically, socially and culturally conservative. The immanent and intentional development thesis propagated by Cowen and Shenton (1996) describe the nature in which mining can precipitate development in both ways. It could be immanent through migration where people move to areas within the vicinity of the mine in order to access employment or any other benefits such as trading opportunities for those who are able to open up small shops selling basic consumer goods such as matches, candles, bicycle parts and so on. These community programmes can be seen as fitting this description. Banks et al (2013) describe this as creating opportunities for people to shift from subsistence 
livelihoods to industrial employment. They further state the immanent and intentional development dichotomy provides a useful framework with which to understand ambiguous development tensions that accompany the large-scale mines (Banks et al 2013). Therefore the success of the education project will depend on collaboration between Barrick Gold and the intended beneficiaries and the government as well as the traditional leaders such as the local tribal chiefs.

In this case study, the community has expressed the need to increase the scope of education to include the wider community, and other livelihood activities such as women's clubs. This shows that the community and indeed the Ministry of Education have great expectations and they would want to see more being done. Even though they have expressed satisfaction with what is currently being done they still think there should be an increase in the number of activities being implemented. Therefore in order for the people in the community to be fully satisfied with the project, more collaboration, accountability and transparency is required so that projects are implemented in such a way that meets the needs of the people. The people in the community and government departments such as Ministry of Education should be more empowered. They should be directly included in decision making so that they can increase their demands and secure longer term investments and sustainable interventions.

Carroll has provided a platform through which companies can be measured with regards to their community development approach to CSR. From the findings, we can observe that if Barrick is placed on Visser (2008) or Carroll's (1996) scale from economic responsibilities to ethical and philanthropic responsibilities, the company will lean towards being economic driven by profits and investment. This is because CSR is not legally binding, and the projects being done are short-term even though construction projects and perhaps scholarships will outlive the mine's lifespan without proper accountability and more sustainable projects it would be naïve to assume that they are philanthropic. We could also conclude that given the scale of mining, these projects are really small in terms of costs. Moreover, Barrick Gold calls the CSR department, Sustainability department and this is only lip service. The explanation is that the community should begin to think of sustainability beyond the mine's lifespan, from the onset and not when the mine is winding down its operations. Personal commitment of some of the staff especially those in the Sustainability department notwithstanding, views and aspirations of the people and the Ministry of Education need to be high valued if CSR is to achieve what it is intended for. I wonder if these are one-off 
tokens, or Barrick Gold actually has a long term 20-year plan to continue carrying out CSR activities for as long as the company lasts.

\subsection{Key findings}

The following findings are what I deduced from the information I gathered beyond what the participants said.

1. Lack of formal documentation and communication is an issue. For example the school did not have minutes of meetings held with staff from Barrick Gold neither did the Ministry of Education. The Ministry of Education did not have formal reports of the education projects that Barrick Gold is implementing in the whole district.

2. Barrick Gold seem to want to implement CSR but on their own terms.

3. People appreciate Barrick Gold's contribution but they still have great expectations and they think more should be done in their community.

4. Local people and Ministry of Education officers are consulted but more veto power is needed for them to have equal power with Barrick Gold in decision making.

\subsection{CSR an aid modality or trade catalyst?}

Since the Ministry of Education policy encourages co-operation it could be an opportunity to work with the private sector in a more formalized and systematic way with clear guidelines. If co-operation between the Ministry of Education at a central government level and private sector is harnessed, it could trickle down to district level and private companies working in different districts could work more collaboratively with the department. Mutual accountability would also enhance alignment, managing for results and harmonization as other Paris principles of aid effectiveness. Even though CSR is not classified as Official Development Assistance in the traditional meaning of the concept, the principle of mutual accountability, alignment and managing for results as prescribed by the Paris Principles of Aid effectiveness are relevant in this case. This is because the Ministry of Education as a policy maker and implementer can work with other partners in order to increase their capacity to provide educational services.

Community participation is necessary for all project implementation. From my experience this helps to avoid implementation of projects which are not supported by the people they are intended for. The tripartite agreements between the community, the Ministry of Education 
and any partner (NGO or private company) helps foster community ownership of the project especially construction projects. To foster ownership further, there is an informal agreement that communities should contribute some local materials for construction projects such as clay bricks, sand and stones. The community mobilization for which the chief and headpersons are influential is a common practice in Zambia. Therefore, community involvement in projects cannot be ignored.

This section of this chapter discusses policy implications for CSR as an aid modality. I argue that CSR can be a form of aid and should be examined as such. I also discuss the opportunities and challenges of CSR and if it has any potential at all to mitigate poverty through community development programmes. This issue of CSR as an aid modality is discussed through the postdevelopment lens. But, before we proceed any further, it is imperative to look at the definition of aid modality, at least the traditional definition of the term.

* Aid definition

Aid modality is the various ways in which a country acquires aid. The most common modalities are general budget support, sector wide approach and project support. This aid is administered in stages either by multi-lateral or bi-lateral donors. Mavrotas (2010) defines aid as financial flows that qualify as Official Development Assistant (ODA) which is the sum of loans and grants to recipient countries. This definition does not include donations from the public and foreign direct investment. The definition is in line with the definition provided by Development Assistance Countries (DAC) donors. According to DAC, ODA is defined as fund flows to aid recipient countries provided by official agencies (including states and local governments or their executing agencies) for economic development and welfare which is concessional by nature and has a grant element of 25 per cent (De Haan, 2009). The overarching principle is that the inflows come for developed countries to developing or least developed countries for various projects and programmes.

Official development assistance is further categorized into four categories; firstly we have the bilateral donors which account for the largest sum of funding from developed countries through ministry of foreign affairs or aid departments. Secondly, the multilateral aid from UN and Bretton Woods institutions, then from NGOs which is a rapidly growing channel and fourthly, private philanthropic organisations which are the newest but certainly becoming a 
significant player in the aid arena, notable among these in Africa is the Bill and Melinda Gates Foundation.

There are some proponents of aid such as Sachs (1999) who believe that aid should increase in quantity, there are others such as Hancock and Easterly who believe that it is a way of the West exerting power. There are those who take the middle line postulating that aid is a form of partnership between states (De Haan 2009). Aid policies and practices have raised more questions in the past two decades with much criticism coming from the countries that provide the aid, as well as Latin America. For example, in 1989 Hancock argued that the aid business should be abolished and highly paid aid bureaucrats or as he termed them, the "lords of poverty' should vacate developing countries because aid had been littered with failures that escaped public scrutiny (De Haan, 2009).

Another criticism of aid was from Easterly (2006) who previously worked for the World Bank as an economist. Easterly argued that "the tragedy is that the West spent \$2.3 trillion on foreign aid over the last five decades and still had not managed to get twelve-cent medicines to prevent half of all malaria deaths" (in De Haan, 2009, p. 7). This is aligned with postdevelopment theory that casts a critical eye on development policy and practice. De Haan (2009) further explains that the US gives the most aid among the DAC donors but their motivations are driven by other political and economic agendas which are tied to the White House and Congress and motives vary from diplomacy, to national security and economic development. Gilberthorpe (2013) also notes that "the World Bank seeks to improve interventions by encouraging greater corporate social responsibility as the vehicle for development that purports to deal with human and environmental issues" (p. 467). This validates the claim by several participants that Barrick Gold should do more than they are currently doing in the community. Whatever the discourse and motivations, there are real people involved with real needs, wants and aspirations and their views should be taken into consideration when allocating funds, planning and implementing projects.

The case for Zambia is similar to that of other countries in sub-Saharan Africa concerning aid and mining. Zambia is rich in copper deposits but it is still among the poorest countries in the world. Previous chapters looked at how CSR from the mining industry is contributing to access to education in Solwezi district. Even though there is visible contribution, more still needs to be done. As stated in an interview with Uranium, the North-western province has lagged behind in terms of education performance. It has been the last among the nine 
provinces or second from last there is still more that needs to be done in the education sector in Solwezi. There is an urgent need for tertiary institutions because students find the universities in other cities too far away and too expensive. The question that this raises is that even with the presence of CSR aiding development in a region - is this enough? To achieve the aspirations of Uranium and other people in Solwezi, integration of economic and social policy would be essential. This is underscored by De Haan's (2009) argument that during the 1970s, international development moved from one centred on economic growth to one more explicitly focused on poverty, redistribution, basic needs, direct anti-poverty interventions and participatory approaches and rural development. In my view, CSR provides a premise for bringing the social into the economic sphere thereby contributing to equitable distribution of economic and other social benefits.

\section{* Corporate Social Responsibility as an aid modality}

CSR has been an increasing practice in Zambia especially seeing that the private sector is more vibrant and the days of humanism and nationalism of business enterprises are over. The private sector out of their moral obligation of wanting to be good corporate citizens are increasingly supplementing government efforts in the provision of social services, health, education and recreation or sports are the major projects the private sector implements. In my view, although there is criticism of aid inflows and policies surrounding this, there is an opportunity to classify CSR funding as an additional type of funding to complement ODA and to create other policies to guide how it is provided and utilized. This would be in order to curb poverty and the lack of access to social services for people and make a contribution to better livelihoods.

Aid effectiveness have become a big agenda, and at the very least it has become increasingly a topic of discussion among DAC and OECD donors. Ownership, alignment, harmonization, managing for results and mutual accountability has been agreed upon as the five overarching principles of aid effectiveness (Joint Progress Toward Enhanced Aid Effectiveness, 2005). These principles give guidelines on how donor and recipient countries ought to conduct themselves with regards to aid. The situation may not have changed much in terms of who decides what should be done with donor funding and how programmes should be implemented, nonetheless it is an acknowledgement that all parties should engage over the issues so that optimal results can be seen. From my view this may be possible for CSR in the immediate term and even more so, than for other forms of aid. 
Development processes do not occur in a vacuum. Policy choices, institutional reforms and public actions implementation are invariably affected by stakeholder interests and power relations. Any consideration of social development outcomes has to take account of power relations and the political economy at different levels (De Haan \& Dani 2008, p. xxiii).

Owing to the fact that development processes should be embedded in prevailing policy structures and actions, I think CSR provides an avenue through which development can be defined and practiced differently. It provides a source of funding for a Sector Wide Approach (SWAp) type of modality, an example of which is Barrick Gold's education projects which are multifaceted.

\section{* Possibilities for CSR as an aid option}

Ownership of projects is key for communities. They can own the projects in terms of dictating what activities should be done and how. For example some people interviewed stated that instead of scholarships for students starting at $10^{\text {th }}$ grade they should start at eighth grade. Some also mentioned that they would rather be assisted with livelihood activities such as gardening or raring poultry so that they can have enough money to take care of their children. If they are given a chance to decide what should be done and how it should be done as opposed to a façade type participation engagement they would be in more control of how projects are implemented.

Profit sharing and keeping funds in trusts and reserves would be a possible way in which the community can benefit from the mine. These funds could be kept for future use. Apart from construction of infrastructure this may be more sustainable because mining is not an everlasting industry, at some point minerals get depleted and companies fold-up and leave in search of other prospects. Haalboom (2012) explains that communities in Suriname have engaged the mining companies on profit sharing and the mine pays a certain percentage of the profit to the community trust. This could be a possibility for Zambia because the community through the royal establishment can actually push for this and be given an amount of the profit to keep in trust funds, probably in one of the local banks. As the funds accumulate, the community through the tribal council can deliberate and decide on what projects they want to undertake and how they want to utilise the funds. 
* Challenges to this approach

Unequal partnerships and hegemony of the West (implied or explicit) may be a hindrance to cooperation. Escobar (1995) and Ferguson (1994) argue that the entire development discourse is Western-created and imbued with the usual dichotomies of Western superiority and this justifies the existence of an interventionist and disempowering bureaucracy and the entire development concept of language and institutions built around it actually causes the problems it is supposedly trying to solve (Uvin 2004, in De Haan 2009). If the private sector can view themselves as a strategic partner and conduct their business with government departments and communities on a level platform, it would create a level of mutual trust and accountability. If the big brother mentality can be 'diluted' it would give the community and government department impetus to state their claim and have their voice heard in such a way that their thoughts, objectives and aspirations are considered.

In my opinion a legal framework that stipulates and regulates how CSR should be implemented by private companies would be appropriate in order to enhance more benefits for the local people. The other challenge would be to get to practically implement the Paris Principles of Aid Effectiveness. For example sharing budget and other implementation information was seen as classified by Barrick Gold. I consider that they would be unable to be totally transparent with all the information because they would not want to make it public. While the Zambia Mines and Mineral Act (2007) is silent on matters of CSR, it does state that the government would like to make Zambia favourable for investment and investors should honour the development agreement. The development agreement only stipulates tax, rent and environmental impact issues. The same observation was made by Uranium when he said there is no legal framework for CSR in the laws of Zambia and it is merely a moral issue which companies show to do but they do not have any legal obligation to do it (Interview $7^{\text {th }}$ May 2013). Currently, if the mining company chooses not to undertake CSR, they will not be disciplined or policed by anyone. In my view this is a lacuna in the development agreements that the Zambian government signs with the investors. Postdevelopment theory hinges of thinking about alternative ways of defining and practising development. CSR can help to increase access to social services by utilising resources made available in the optimal way possible. Hence my suggestion of looking at CSR through an aid modality lens. 


\subsection{Conclusion}

Barrick Gold implements several community projects as part of their CSR programme. This research focuses on their education project in Solwezi District, through primary research in the form of interviews with stakeholders and a focus group with community members. Although there are many needs in this district as illustrated through the array of responses identifying several community needs, this research placed more emphasis on education because education is one of the avenues through which the community can acquire skills for a better livelihood. This chapter has discussed the benefits of CSR and what needs to improve in the way that Barrick Gold implements CSR from the local people's point of view. Mining as an extractive industry is seen as highly profitable for companies and shareholders. For this reason, Barrick Gold should not continue implementing CSR at such a small scale. There are competing needs because the mine also needs to make a profit for the investors as well as remain good corporate citizens so that they maintain a good reputation. It is perceived that this good image, which can be achieved through CSR, increases profits. There is no easy solution to striking a balance between these issues and pleasing all the stakeholders on either side. The company has to make a profit for the shareholders in order for funding to be available for CSR activities.

This chapter has answered the last three research questions, and described and analysed the perceptions of the people of Solwezi, the Ministry of Education officers. It also discussed CSR as an aid modality in light of these findings. How do we ensure sustainability and equality? There are no simplistic answers or solutions to the complex poverty problems of resource dependent countries like Zambia. The next and final chapter concludes this research and shows my personal perspective towards CSR from my research findings and reflections. I endeavour to suggest some policy and practice changes, having learnt lessons from Latin America that would be helpful for the Zambian context and for CSR in general. It is my conviction that CSR is a potential funding source for community and social development, and that it will need to be channelled correctly with consensus and collaboration from all stakeholders; the community, the government department and the private sector. 


\section{CHAPTER SIX \\ Summary and conclusion}

\subsection{Introduction}

This research set out to explore how the local people in the community and the Ministry of Education officers perceive mining and corporate social responsibility. A review of the literature showed that mining has been a major part of Zambia's economy from the time commercial mining started in the late 1928. CSR though a global phenomenon is new in Zambia and has been part of Zambia's mining sector since the mid-1990s when the mines where privatised.

The analysis of the perceptions of the people of Solwezi and the Ministry of Education officers is that much as they appreciate the benefits of CSR they still believe more can be done in the area of education. The rest of this conclusion gives a summary of mining in Zambia, then discusses postdevelopment. I move on to discuss feminist approaches, limitations and areas of further research. Lastly, I give my concluding remarks.

\subsection{Concluding discussion}

Mining is the largest industry in Zambia which contributes over 70 percent of the total income of the national treasury. Even though mining is an extractive industry by nature, in the name of 'good corporate citizenship' the mining companies are doing what they can to plough back resources into the host community. The preceding chapter explains the findings from the primary research conducted about a CSR project in Solwezi and discusses the possibility of CSR being an aid modality. I described and analysed the perspectives of the local people, the chief, teachers and officers from the Ministry of Education and from Barrick Gold. I have also discussed the challenges and opportunities of CSR as an aid modality in the context of the current practice. This chapter brings the whole thesis to a close and discusses limitations and implications of this research and I suggest future research possibilities.

This research has been a journey through the mining sector in Zambia. In Chapter three I traced the history of mining globally and more specifically in Zambia and explained how mining has affected people's livelihoods. Artisan mining was taking place in Zambia during pre-colonial times, but it was not until 1928 when it was established as a commercial business. Commercial mining at this time had undercurrents of British control through the 
British South African Company because Northern Rhodesia (as Zambia was called then) was a British Colony at this time. This explains the capitalist framing of mining, its implication during the pre and post-colonial era.

The privatisation process in 1990s was underpinned by uneven power relations and the Zambian Government was at the mercy of the investors and influenced by the World Bank. People came from all over the country especially from rural areas, and from other countries in Southern Africa and from Asia and Europe, to work in the mines. I also explained how as the decades progressed, mines became more than an employer with the role of providing social welfare, in the sense that the mine was supposed to provide for all the needs of people (cradle to grave). The model was a justification for Structural Adjustment Programmes imposed by the World Bank and IMF in subsequent years not only with new owners after privatisation of all the mines but even with the Zambian management of the mines because profits were not being ploughed back into the business.

The welfare system provided by mining companies evolved to become CSR which is neither mandatory nor a legal requirement. However, it is an ethical and economic obligation which companies have opted to do. I have also demonstrated how mining was treated as a "cash cow" by the Zambian government without corresponding recapitalization and reinvestment into the industry. This and other factors such as low prices on the LME, reduced production and other economic hardships that followed led to the privatisation of the mines. This was no easy option but there was no other course of action to take. This harsh reality created a situation where jobs were scarce and social services dwindled. However, the copper prices increased again on the LME in the mid-2000s and new mines opened up in what is dubbed the New Copperbelt (Solwezi), the provincial capital of North-western province.

I have discussed the history of CSR and the different ways in which it is currently being practised by different companies. I gave some definitions and key CSR debates based on various authors' and practices. The mining companies in the New Copperbelt, Barrick Gold and First Quantum Minerals, are both engaged in CSR working on a myriad of social projects such as education, health, HIV and AIDS and water. This thesis researched the education projects supported by Barrick Gold. The importance of this is not only in relation to other social issues, but is also in the context of how education is a way in which the people of Solwezi can derive economic, social and other benefits from the mining companies who have invested in their area. I showed how CSR can be an opportunity to integrate economic and 
social policy, in addition to being an aid modality. The key debates around CSR from different authors and companies and with varying perspectives of CSR as an aid modality. Some consider it is philanthropic, others that it is ethical and legal and others that it is more for economic purposes for the company to make more profit if they are seen as a "good" corporate entity.

This thesis focused on local voices and perspectives around impact of CSR in education in Solwezi. As I listened to the people from the community, school and Ministry of Education staff I realised that several things: firstly, although people value CSR due to the contribution being made in the education sector, they still think that more needs to be done and there is still room for improvement. Secondly CSR can be a form of aid for social development but the complexity of accountability partnership and participation still need to be addressed by Barrick Gold in particular. Thirdly, there are still issues of power relations that need to be negotiated so that the people in the community and the Ministry of Education are not vulnerable and disempowered. Lastly I also realise that more sustainable projects or investment is needed if the community is to "reap real benefits" from the mine.

One of the critiques of aid from postdevelopment perspectives is the hegemony of the West, whereby developed countries exert pressure on the other countries and practice a form of control on their resources. For example, Zambia as a copper producing nation is a price taker and cannot set the price at which copper is sold (Fraser, 2010). Therefore, the Zambian government and indeed the investors will sell copper at the price pre-determined by the LME. African and other resource-based countries have to adhere to prices set by the market forces. Orbie (2007) suggests that the idea of commodity pricing regulation faces resistance for several commodities in addition to minerals and oil, including tea, cocoa, cotton and sugar. This pricing situation gives currency to the idea of Western hegemony, and African countries have no choice but to comply with the prices set by external powers. It augments the power relations whereby regardless of Zambia's mineral resources, Zambians cannot determine the price at which these minerals are sold. This shows the disparities between the developed and 'developing' countries. For example, Glencore, a commodities trading company, has been cited for tax evasions (as discussed in Chapter two) but nothing has been done to address this.

For example the CEO at Barrick Gold in Zambia is a white male of Western origin. Race, class and gender remain critical issues in a case like Barrick Gold's Solwezi mine. For example, white males tend to be employed in higher paying jobs and live in better housing 
with their children attending better schools. The majority of the mine workers, who are Zambian, live in modest housing and their children attend modest schools. Yet Zambians are still grateful that they have jobs, and living without this work could be much worse. Therefore in applying postdevelopment as a theoretic lens and feminist approaches in this thesis, I have been able to interrogate power relations and hierarchies the underpin the manner in which mining is done in Zambia and how these uneven power relations also shape how CSR is practiced.

On the other hand feminist approaches encourage interaction between the researched and the researcher. This philosophical approach questions power relations and hierarchies and seeks empowerment for the research participants. With this backdrop, I have been seeking to contribute to empowering the people of Solwezi through the analysis of this case, which provides valuable information for the staff in the Sustainability Department at Barrick Gold. More importantly, the people in the community, the chief, teachers, school managers and officer at Ministry of Education. I have sought to decipher how the situation could improve for Africa in general, and Zambia in particular, to better undertake community development and provide social services. While I recognize that I cannot prescribe simplistic answers to complex problems, I still believe it is worth trying to ask these questions and seek answers. One contentious issue I have been grappling with is the voices of the people in Solwezi and those of Ministry of Education jointly planning and implementing development projects because in my view they understand the local needs and solutions better than Barrick Gold identifying these without such involvement. This builds capacity, ownership and continuity among the local people and the Ministry of Education.

I also employed the feminist approaches as my philosophical approach because it enabled me to reflect on my work, interact with my research participants, and seek to empower them and myself in the process. It also helped me question and examine the power relations between Barrick Gold, the people in the community and the Ministry of Education. The people in the community are by no means a homogenous group; they too have their own hierarchies and power struggles, and these are exacerbated by external factors such as Barrick Gold.

Therefore this research put perspectives of people in the community at the centre and sought to get perspectives from the people in community who are the intended beneficiaries of the CSR project. I also document the impressions of Ministry of Education concerning the education projects Barrick Gold is implementing. It is clear that more synergy, collaboration, 
stronger partnership and cooperation is required if the projects are to give the people optimal results. By putting these voices at the core of my research, I am hoping to challenge the unequal power relations.

\subsection{Recommendations}

1. The Ministry of Education have a policy document and in my opinion they should share this with Barrick Gold so that education projects are implemented to supplement what Ministry of Education is doing.

2. The Central Government should formulate and enforce regulatory frameworks so that CSR can conform to the requirements of this regulation and not just an adhoc activity.

3. It would be better to increase the capacity of the government to provide these services because they will remain after the mining company has depleted the copper and left the area.

4. Barrick Gold also have community engagement and sustainability policies, they should also share these with the Ministry of Education so that they have a common understanding on how they intend to implement CSR projects.

5. My final recommendation on this matter of communication and accountability is that Barrick Gold should be more transparent and accountable jointly plan projects with the people in the community and the Ministry of Education. In addition the Ministry of Education officers should demand more from Barrick Gold in terms of formal communication and written reports.

\subsection{Future research}

Future research is required on the integration of economic and social policy and practice. The key question would be how the private sector can contribute to provision and access of social services such as education, health and agriculture. Future research is also required on the need for more expenditure in access to education and health services as essential drivers and contributors to economic growth. CSR is just one avenue through which this integration can be achieved but more needs to be done. There is also need for further research to define and document good practices of CSR in other countries within sub-Saharan Africa and adapt these practices to Zambia. Furthermore, it is important for more research to understand how other local people view CSR, especially in a sensitive sector such as mining which has to do 
with land and other natural resources such as rivers, mountains and trees which they hold in high esteem as important sources of livelihood, identity, history and tradition. It would also be good to hear from the children themselves who are direct beneficiaries of projects and how schools, clinics, water systems or any other CSR projects impact them. Their aspirations and suggestions regarding CSR would also be useful. Solwezi District also provides a good case study for analysing how the mining sector affects people and the environment in Zambia. The issue of environmental consequences of mining has been a point of discussion in many mining dependant countries and Solwezi being a new mining area would be a good case for more research and innovation in environmental sustainability.

\subsection{Limitations of this research}

Time and resources could not permit me to stay much longer in the field. As such, this could not be action-research and I was unable to advocate for increased and more community-led CSR projects to Barrick Gold and mining companies in the immediate term. However, I am convinced that the findings of this thesis will be valuable for those wishing to undertake such advocacy in future because I intend to share reports with Barrick Gold, the community, schools and Ministry of Education. Another limitation for the research was the lack of documents publicly available. For example, I did not have access to school attendance records for previous years and this made comparison impossible in terms of what the situation was before Barrick Gold started implementing CSR activities. I obtained some documents from Barrick Gold but most policies they mentioned during interviews were considered as confidential. This limited my ability to compare and corroborate information.

\subsection{Concluding remarks}

Africa as a continent is rich in natural resources. It is paradoxical that it is classified as poorest continent and so questions must be asked. More aid in terms of loans, grants, foreign direct investment, CSR and philanthropy flows into Africa more than any other continent. It is very difficult to reconcile how a resource rich continent can be called a dark continent, under developed, least developed, developing, Third World, and any other term that exists in the plethora of development speak. There are no easy answers. In fact, there are more questions to be asked. How did Africa get to this place of despondency? Is there really ever going to be a time when all people are equal and treat each other as such? I do not have the answers either but these are the questions in my mind. 
I have discussed mining, CSR, education and postdevelopment using feminist approaches as my philosophical approach. The literature revealed how different companies around the world view and practice CSR. It also revealed how mining in its current form as a capitalist activity can cause harm to peoples' livelihood and how the host community and to a certain degree the host country is usually on the losing end. My fieldwork explained the aspirations and suggestions of the people of Solwezi. For me, this is the central finding of this thesis, what they think, feel and see in the whole spectrum of mining and CSR projects. Although policy and practice cannot change overnight, I firmly believe it is worth trying to look into these deep-seated issues and seek some answers. The change in the manner of CSR operations which Chevron is implementing in Niger Delta is a ray of hope that things can change for the better no matter how long it takes.

As one long journey begins with one step, I know this is one step in bringing equality and equitable distribution of resources, as opposed to the current 'winner takes all' scenario. As things stand, the struggle for me and my people continues. Thus this study is not exhaustive, but rather I have endeavoured to add to the on-going debate about development as a Western construct, and its definitions, assumptions and solutions. I will end with a quote from one of the research participants, Uranium, who stated that "development is not development until it can impact positively on people's lives." I would like to further add that if the CSR being implemented does not impact positively on the people in Solwezi, then it is as good as tokenism, or, as I would call it, copper-plating. 


\section{Bibliography}

Allouche, J (2006) Corporate social responsibility concepts, accountability and reporting. Hampshire: Palgrave Macmillan.

Alstine, J. V. \& Afionis, S, (2013). Community and company capacity: The challenge of resource-led development in Zambia's 'New Copperbelt.' Community Development Journal, 48(3), 360-376.

Amott, T. \& Matteai, J. (1996) Race, Gender and Work: A Multi-Cultural Economic History of Women in the United States. Boston: South End Press.

Auty, R.M. (1993) Sustaining Development in Mineral Economies: The resource curse thesis. London: Routledge.

Auty, R.M. \& Mikesell, R.F. (1998) Sustainable development in mineral economies. Oxford: Clarendon Press.

Bank of Zambia (2013) Press Release, Bank of Zambia, Lusaka.

Banks, G. (2008) Understanding resource conflicts in Papua New Guinea. Asia Viewpoint, 49(1), pp 23-34.

Banks, G.; Kuir-Ayius, D.; Kombako, D. \& Sagir, B. (2013) Conceptualising mining impacts, livelihoods and corporate community development in Melanesia. Community Development Journal, 48(3), pp 484-500.

Barrick Gold (2013) Lumwana Mine CSR activities. Solwezi: Barrick Gold.

Bendell, J. (2005) In whose name? The accountability of corporate social responsibility. Development in Practice, 15(3\&4), pp 362-374.

Bill \& Melinda Gates Foundation. (2013) What we do. Retrieved $15^{\text {th }}$ September 2013 from http://www.gatesfoundation.org/What-We-Do/Global-Health/HIV

British Broadcasting Corporation (2012) Why Poverty Documentary. Accessed 6 November 2013 from http://www.youtube.com/watch?v=WNYemuiAOfU.

Bulmer-Thomas, V. (2003). The economic history of Latin America since independence. Cambridge: Cambridge University Press.

Carmody, P. R. (2007) An Asian-driven economic recovery in Africa? The Zambian Case. World Development, 37(7), pp 1197-1207.

Carmody, P. R. \& Owusu, F. Y (2007) Competing hegemons? Chinese versus American geoeconomic strategies in Africa. Political Geography, 26, pp 504-524.

Chambers, R. (1983) Rural development, putting the last first. England: Longman Group.

Cowen, M \& Shenton, R. (1996) Doctrines of development. London: Routledge. 
Cramer, J. (2006) Corporate Social Responsibility and Globalization, An action plan for Business. Sheffield: Greenleaf Publishing.

Creswell, J. W. (2009) Research design qualitative, quantitative mixed methods approaches. California: Sage Publications Inc.

Crang, M. \& Cook, I. (2007) Doing ethnographies: Analysing field materials. London: Sage Publications Ltd.

De Haan, A. (2007) Reclaiming social policy: Globalisation, social exclusion and new poverty reduction strategies. Hampshire. Palgrave Macmillan.

De Haan, A. (2009) How the aid industry works, an introduction to international development. Sterling, Kumarian Press.

Devex Impact Editor (2013) Beyond philanthropy: What happens when a multinational creates its own development agency. Accessed on 19 November 2013, https://www.devex.com/en/news/beyond-philanthropy-what-happens

England, K. V. L. (1994) Getting personal: Reflexivity, positionality and feminist research. Professional Geographer, 46(1), pp 80-89.

Escobar, A. (1995) Encountering development: The making and unmaking of the Third World. New Jersey: Princeton University Press.

Ferguson, J. (1999) Expectations of Modernity: Myths and Meanings of Urban Life on the Zambian Copperbelt. Berkeley: University of California Press.

Frame, B. (2005) Corporate Social Responsibility: a challenge for the donor community. Development in Practice, 15(3\&4) pp 422-432

Fraser, A. (2010) Introduction in Fraser, A. \& Larmer, M. (Eds) Zambia, Mining and Neoliberalism, Boom and bust on the globalised Copperbelt. New York: Palgrave Macmillan.

Fraser, A. \& Lungu, J. (2007) For whom the wind falls? Winners and losers in the privatisation of Zambia's copper mines. Lusaka: Catholic Centre for Justice Development and Peace.

Fredrick, W. C. (1988) Business and society, corporate strategy, public policy, ethics. U.S.A: McGraw-Hill Inc.

Freeman, T. (2006) 'Best practice' in focus groups research: making sense of different views. Journal of Advanced Nursing, 56(5), pp491-497.

Fonterra (2013) Accessed 28 ${ }^{\text {th }}$ August 2013

https://www.fonterramilkforschools.com/news/school-milk-now-inthebop-and-gisborne-1462

Garvey, N. \& Newall, P. (2005) Corporate accountability to the poor? Assessing the 
effectiveness of community based strategies. Development in Practice 15(3\&4), pp 389-404

Gewald, J.B. \& Soeters, S. (2010) The case of Luanshya/Baluba in Fraser, A. \& Larmer, M. (Eds) Zambia, Mining and Neoliberalism, Boom and bust on the globalised Copperbelt. New York: Palgrave Macmillan.

Gibson-Graham J. K. (2005) Surplus possibilities: Post development and community Economies, Singapore Journal of Tropical Geography, 26(1), pp 4-26.

Gilberthorpe, E. (2013) Community development in Ok Tedi, Papua New Guinea: the role of anthropology in extractive industries, Community Development Journal, 48(3), pp 466-483.

Gilberthorpe, E and Banks, G (2011) Development on whose terms? CSR discourse and Social realities in Papua New Guinea's extractive industries sector, Resources Policy. 37(2), pp 185-193.

Graulau, J. (2008) Is mining good for development? The intellectual history of an unsettled question. Progress in Development Studies, 8(2), pp 129-162.

Haalboom, B. (2012) The intersections of Corporate Social Responsibility guidelines and Indigenous Rights: Examining neoliberal governance of a proposed mining project in Suriname. Geoforum 43, pp 969-979.

Harris, E. \& Kende-Robb, C (2008) Integrating macroeconomic policies and social objectives in Dani, A. A. \& De Haan, A. (Eds) New frontiers of social policy; Inclusive states social policy and structural inequalities. Washington DC: The World Bank

Hay, I (2010) Qualitative Research Methods in Human Geography. Canada: Oxford University Press.

Idemudia, U (2011) Corporate social responsibility and developing countries: moving the critical CSR research agenda in Africa forward. Progress in Development Studies, 11(1), pp1-18

Johnston, R. G.; Gregory, D.; Pratt, G. (2000) Dictionary of Human Geography. Massachusetts: Blackwell Publishers.

Kabeer, N. (2005) Gender equality and women's empowerment: A critical analysis of the third Millennium Development Goal. Gender and Development, 13(1), 13-24.

Kakabadse, A. and Kakabadse, N. (2007) CSR in practice delving deep. Hampshire: Palgrave Macmillan. 
Kakabadse, A. and Morsing M. (2006) Corporate social responsibility: Reconciling aspiration with application. Hampshire: Palgrave Macmillan.

Kalumbi, J \& Mukuka, P. (2013) The monthly bulletin. Lusaka, Zambia: Central Statistics

Kiikpoye, K. A. New corporate social responsibility models in oil companies in Nigeria's delta region: What challenges for sustainability? Progress in Development Studies, 12(4), pp 259-273.

Kindon, S. \& Wood, E.S. (2009) Participatory action research in geographic teaching, learning and research. Journal of Geography in Higher Education 33(1) pp19-32.

Kitchin, R. and Tate, N. (2000) Conducting research in human geography. Harlow: Pearson Education.

Lambert, T. (N.D.) Accessed $15^{\text {th }}$ December 2013, www.timeline of Zambia

Lindgreen, A and Swaen, V (2010) Corporate social responsibility. International Journal of Management Reviews, 12(1) pp 1-7.

Loluave, B.J. (2011) Is sustainable development a faceless rhetoric? An assessment of educational sustainability at the Porgera Mine, Papua New Guinea. (Unpublished Masters' thesis) Massey University, Palmerstone North, New Zealand.

Loxley, J. (2013) Are public-private partnerships (PPPs) the answer to Africa's infrastructure needs? Review of African Political Economy, 40(137) pp 485-495.

Lungu, J. (2008) Copper Mining Agreements in Zambia: Renegotiation or Law Reform? Review of African Political Economy, 35(117), pp 403-415.

Lungu, J. (2008) Socio-economic change and natural resource exploitation: A case study of the Zambian copper mining industry. Development Southern Africa, 25(5) pp 543-560.

Lungu, J \& Mulenga, C. (2005) Corporate social responsibility practices in the extractive industries in Zambia. Ndola: Mission Press.

Macmillan, H. (2012) Mining housing and welfare in South Africa and Zambia: an historical perspective. Journal of Contemporary African Studies, 30(4), pp 539-550.

Maconachie, R. \& Hilson, G. (2013) Editorial introduction: The extractive industries, community development and sustainable livelihood change in developing countries Community Development Journal, 48(3), pp 347-359.

Mandela, N. (1995) Long walk to freedom. London: Abacus.

Mapsof.net (2013) Accessed $15^{\text {th }}$ November 2013, http://mapsof.net/zambia.

McEwan, C (2011) Postcolonialism, feminism and development: intersections and dilemmas. 
Progress in Development Studies (1) 2 pp 93-111.

Ministry of Education (1996) Educating our future, Lusaka, Zambia: Ministry of Education.

Ministry of Finance and National Planning (2006) Vision 2030, A prosperous middle-income nation by 2030. Lusaka, Zambia: Ministry of Finance and National Planning.

Ministry of Mines (2007) Zambia Mines and Minerals Act, Lusaka, Zambia.

Ministry of Mines.

May, S. (2007) The debate over corporate social responsibility, Oxford: Oxford University Press.

Moyo, D. (2009) Dead aid. London: Penguin Group.

Mususa, P. (2012) Mining, welfare and urbanization: the wavering urban character of Zambia's Copperbelt. Journal of Contemporary African Studies, 30(4), pp 571-587.

Murray, W. E. \& Overton, J. D. (2011) Progress in Development Studies 11(4) pp 307-319.

Nast, H. J. (1994) Women in the field: Critical feminist methodologies and theoretical perspectives. Professional Geographer 46(1), pp54-66.

Negi, R. (2010) The mining boom, capital and chiefs. In Fraser, A. \& Larmer, M. (Eds) Zambia, Mining and Neoliberalism, Boom and bust on the globalised Copperbelt. New York, Palgrave Macmillan.

Okonjo, I. N. (2012) Aid versus Trade. Accessed 8 August 2012 from http://www.viewchange.org/videos/ted-ngozi-okonjo-iweala-on-aid-versus-trade.

Ontiveros, S. R. (1986) Corporate social responsibility contemporary viewpoints. Oxford: Clio Press.

Orbie, J (2007) The European Union and the commodity debate: From trade to aid. Review of African Political Economy. 112, pp 297-311.

Palomino-Schalscha, M. A. (2012) Indigeneity, autonomy and new cultural spaces: The decolonisation of practices, being and place through tourism in Alto Bio-Bio, Chile. (Unpublished PhD thesis) University of Canterbury, Christchurch.

Petrick, J. A. (2009) Corporate social responsibility. In Winkel, C. (Ed) Encyclopaedia of Business in Today's World, 405-407.

Phillips, M. (2005) Contested words; An introduction to Human Geography. Burlington: Ashgate.

Potter, R.B.; Binns, T.; Elliot, J.A. \& Smith, D. (2008) Geographies of development. An introduction to development studies. Edinburgh: Pearson education Limited.

Rahnema, M. \& Bawtree, V. (1997) The Post-development Reader. London: Zed Books. 
Rist, G. (1997) The history of development from Western origins to global faith. Zed Books, London.

Rose, G (1993) Feminism and geography: The limits of geographical knowledge. Oxford: Polity.

Rose, G (1997) Situating knowledges: positionality, reflexivities and other tactics. Progress in Human Geography 21(3) pp 305-320.

Scheyvens, R. \& Storey, D. (2003) Development fieldwork, A practical guide.

London: Sage Publications.

Schech, S. \& Haggis, J. (2002) Development a cultural reader. Oxford: Blackwell Publishers.

Schuermans, N. \& Newton, C (2007) Being a young and foreign researcher in South Africa: Towards a postcolonial dialogue. Singapore Journal of Tropical Geography 33(3), pp 295-300.

Sen, A. (2000) Education as freedom. New York: Anchor Books.

Servos C. M. \& Marcuello C. (2007) NGOs, corporate social responsibility and social accountability: Inditex vs. Clean Clothes, Development in Practice 17(3) pp393-403.

Sharpe, J. P. (2009) Geographies of postcolonialism: Spaces of power and representation. London: Sage.

Sidaway, J.D. (2007) Spaces of postdevelopment, Progress in Human Geography 31(3) pp 345-361.

United Nations (2013) We can end poverty: Millennium Development Goals 2015 and beyond. Retrieved 14 November, 2013 from http://www.un.org/millenniumgoals/.

Usunier, J.; Furrer, O. \& Furrer-Parrinjaquet, A (2011) The perceived trade-off between corporate social and economic responsibility: A cross-national study., International Journal of Cross Cultural Management 11(3) pp 279-302.

Visvanathan, N. et al (1997) The women, gender and development reader. London: Zed books.

Visser,W.; Matten, D.; Pohl, M. \& Tolhurst, N. (2007) The A to Z of Corporate Social Responsibility. Sussex: John Wiley \& Sons.

Wall, C. (2008) Buried treasure: Discovering and implementing the value of corporate social responsibility. Sheffield: Greenleaf Publishing.

Walter, M. \& Martinez-Alier J. (2011) How to be heard when nobody wants to listen: Community action against mining in Argentina. Canadian Journal of Development 30(1-2), pp 281-301. 
Wikipedia (2013) Accessed October 2013 http://www.google.co.nz/imgres?imgurl=http://upl oad.wikimedia.org/wikipedia/commons/1/1a/Copperbelt districts.png\&imgrefurl=http://com mons.wikimedia.org/wiki/

Yakovleva, N., Brust, D.V., \& Mutti, D. (2008) Corporate social responsibilities of mining companies in Argentina. Research Center for Business Relations Sustainability and Society, United Kingdom: Cardiff University Press.

Yin, R. (2009) Case study research design and methods. London: Sage Publications.

Zambia Maps (2013) Copperbelt Districts. Retrieved 19 November 2013 from http://mapsof.net/map/copperbelt-districts

Zambian Watchdog (2013) Accessed 6 November 2013 from www.zambianwatchdog.com

Zambia Weekly (2013) KCM to lay off workers. Accessed 8 November 2013 from http://zambia-weekly.com/ 


\section{APPENDICES}

\section{INFORMATION SHEET FOCUS GROUPS}

\section{CORPORATE SOCIAL RESPONSIBILITY IN THE MINING SECTOR IN ZAMBIA}

My name is Womba Mayondi I am studying at Victoria University of Wellington (VUW). I am collecting information for my Master's Thesis in partial fulfillment of my degree. My topic is Corporate Social Responsibility (CSR) in the Mining Sector in Zambia. This research project will specifically look at the education projects undertaken by the mining company in your area. The research aims to examine the impact of a Corporate Social Responsibility funded primary education project in Zambia's mining sector. This research also intends to explore whether CSR can provide viable funding to facilitate increased access to education in Zambia.

I am therefore going to hold a focus group discussion with the people who benefit from CSR. These focus groups interviews will enable me to gain an in-depth understanding of how CSR works in practice from the perspective of the beneficiaries in the community.

The focus groups will last for one and half hours approximately. They will be recorded in writing with prior consent from the participants. I will ask you some questions and I assure you that the information will be used solely for the purpose of my academic research. It will be treated confidential, meaning your name or identity will not be disclosed and nothing you say will be attributed to you or your community. You can refuse to answer a question without providing any reason for your decision.

Once I have carried out all focus groups, I will analyse the information. All the research material from focus groups will be kept secure and only me and my supervisor will have access to it. The materials will be kept in a locked cabinet and password protected file on the computer. The material will be destroyed two years following the conclusion of the research.

The information will be used in the following ways;

(i) publication in academic or professional journals

(ii) dissemination at academic or professional conferences

(iii) deposit of the research paper or thesis in the University Library (student research)

(iv) To generate information for more effective CSR for Barrick Gold and other corporate firms in Zambia.

I will conduct the focus group with two research assistants who will help with translation and note taking. They have signed confidentiality agreements which state that they shall under no circumstances divulge any information to anyone. 
You can request feedback from me through contacting me on phone or email.

This project has been approved by the VUW Human Ethics Committee.

\section{Womba Mayondi}

Phone: +64211314456 NZ or +260968401651 Zambia

Email: mayondwomb@myvuw.ac.nz

\section{Supervisor}

Dr. Marcela Palomino Schalscha

Email: marcela.palomino-schalscha@vuw.ac.nz

Phone: +6444635899

Note: This information will be explained in the local language for community members. Translation will be done in Zambia and those who can read the local language will be given copies to read. There are however some who can only speak but cannot read. 


\section{INFORMATION SHEET INTERVIEWS}

\section{CORPORTAE SOCIAL RESPONSIBILITY IN THE MINING SECTOR IN ZAMBIA}

My name is Womba Mayondi I am studying at Victoria University of Wellington (VUW). I am collecting information for my Master's Thesis in partial fulfilment of my degree. My topic is Corporate Social Responsibility (CSR) in the Mining Sector in Zambia. This research proposal will specifically look at CSR activities undertaken by mining companies. I will investigate one mining company and its education interventions in Zambia. If the private sector has resources to offer mainstream development practice for social services then it is a potential source of funding that communities and governments and communities could utilise. The research aims to assess the impact of a Corporate Social Responsibility funded primary education project in Zambia's mining sector. This research also intends to explore whether CSR can provide viable funding approaches to facilitate access to education in Zambia.

I am therefore going to interview and conduct focus groups with the people who benefit from CSR, the leaders in the community, staff who actually work in the CSR department, staff at the school and at the Ministry of Education. This will enable me generate and triangulate the information in order to have an in-depth understanding of how CSR is done and the linkages with local people and government department in charge of education.

The interviews and focus groups will last for one and half hours approximately. They will be recorded on an audio device and with prior consent from the interviewees. Otherwise notes will be taken down manually and clarification over certain points will be sought. You can refuse to answer a question without providing any reason to do so. You can also request that the recorder be turned off.

I will ask you some questions and I assure you that the information will be used solely for the purpose of my academic research. It is confidential, meaning your identity will not be disclosed and nothing you say will be attributed to you. I will just state the facts without specific attribution to any individual or group. All material will be kept secure and only the researcher will have access to it. Recordings and other materials will be kept in a locked cabinet and password protected file on the computer. The recordings and notes will be destroyed two years following the conclusion of the research.

The information will be used in the following ways;

(i) publication in academic or professional journals

(ii) dissemination at academic or professional conferences

(iii) deposit of the research paper or thesis in the University Library (student research)

(iv) To generate information for more effective CSR for Barrick Gold and other corporate firms in Zambia. 
I will conduct the interview with one research assistant will help me with note taking. Because the information required is confidential. To this effect he has signed a confidentiality agreement which states that under no circumstances will be divulge any information to anyone.

You can request feedback from me through contacting me on phone or email.

This project has been approved by the VUW Human Ethics Committee. 


\section{CONSENT FORM FOCUS GROUP PARTICIPANTS}

\section{CORPORATE SOCIAL RESPONSIBILITY IN THE MINING SECTOR IN ZAMBIA}

\section{Researcher:}

WombaMayondi

Phone...... $+64211314456 \mathrm{NZ}$ or +260968401651 Zambia

Email........mayondwomb@myvuw.ac.nz

\section{Supervisor:}

Dr. Marcela Palomino-Schalscha

Email: marcela.palomino-schalscha@vuw.ac.nz

Phone: +6444635899

The research has been explained to me and I have understood this research project and what is required. I will participate in the focus group discussion with other colleagues. The discussions will be confidential and I can seek clarification before I respond. I can decline to answer a question without giving any reasons. I understand that the information will be kept confidential and the published results will not use my name, no opinions will be attributed to me in anyway.

I understand the results of this project might be published as Womba's Master's thesis and also in a journal article, book chapter or conference presentation, and/or will be given to her University, the Zambian Ministry of Education and Barrick Gold. This information (the discussion responses) will be destroyed two years after completion of the project.

I understand that I can either give oral recorded or written consent based on my preference.

I hereby give responses to the questions below:

Tick circle where appropriate

I agree to take part in this research.

I would like to receive a written summary of the results of this research when it is completed

Sign:

Name:

Date:

Note: The information in this form will be explained in the local language for members of the community. Translation will be done in Zambia for those who can read the local language because some cannot read the local language but they can speak it.

There will be a consent form for each participant whether focus groups or interviews. 


\section{CONSENT FORM FOR INTERVIEWS}

\section{CORPORATE SOCIAL RESPONSIBILITY IN THE MINING SECTOR IN ZAMBIA}

\section{Researcher:}

Womba Mayondi

Phone...... +64211314456 NZ or +260968401651 Zambia

Email.........mayondwomb@myvuw.ac.nz

\section{Supervisor:}

Dr. Marcela Palomino-Schalscha

Email: marcela.palomino-schalscha@vuw.ac.nz

Phone: +6444635899

The research has been explained to me and I have understood this research project and what is required. I have had an opportunity to ask questions and seek clarification before I respond. I understand that I can request for the tape recording to be stopped and I can also decline to answer a question without giving any reasons. I understand that the information will be kept confidential and the published results will not use my name, no opinions will be attributed to me in anyway.

I understand the results of this project might be published as Womba's Master's thesis and also in a journal article, book chapter or conference presentation, and/or will be given to her University, the Zambian Ministry of Education and Barrick Gold. I also understand that pictures will be taken and I can decline if I do not wish pictures to be taken. The information (interview responses) will be destroyed two years after completion of the project.

I understand that I can either give oral recorded or written consent based on my preference.

I hereby give responses to the questions below:

Tick circle where appropriate

I agree to take part in this research.

I would like to receive a written summary of the results of this research when it is completed

Sign:

Name:

Date:

There will be a consent form for each participant whether focus groups or interviews. 


\section{CORPORATE SOCIAL RESPONSIBILITY IN THE MINING SECTOR IN ZAMBIA}

\section{Questions for focus group discussion}

Focus Group Discussions with members of the community and some of the children who go to the school being supported by Barrick Gold, the chief and headpersons. They will be selected from among community members in the vicinity of the school.

The same questions will be used for the Chief and headmen who will not be part of the focus groups.

1. How long has this school been in existence?

2. When did the mine start supporting the school?

3. Were consultations held before the projects begun?

4. What has changed at the school since the project began?

5. In your opinion, why is the situation this way?

6. Describe your relationship with the mine in terms of project implementation?

7. Describe your relationship with the community?

8. What is your opinion of the kind of education services you had in the past say 4 or 5 years ago?

9. What is it like now and please explain your answer?

10. What is the gender distribution of pupils at the school?

11. What was it before Barrick Gold started implementing the project?

12. If you could tell BG to do something better what would it be?

Note: For the focus group discussion all questions will be asked in the local language. They will be encouraged to respond in the local language. 


\section{CORPORATE SOCIAL RESPONSIBILITY IN THE MINING SECTOR IN ZAMBIA}

\section{Questions for Key Informant Interview}

Different key informants will be interviewed. They are; the CSR Managers, Officers and staff depending on availability. I hope I can have at least 2 staff members from Barrick Gold.

1. Does the mining company have a written CSR strategy?

2. When was it formulated?

3. Who formulated it?

4. This being a global corporation, is the CSR strategy in Zambia different from other countries?

5. Who is responsible for ensuring that the mandate of the strategy is met?

6. Who are the primary and secondary beneficiaries?

7. What are the selection criteria for beneficiaries?

8. What approach is used to implement projects? i.e. who does assessments? Who implements? Are there any cultural considerations? What is the relationship between Barrick Gold, Ministry of Education and the community?

9. Who conducts evaluations?

10. What relationship do you have with the Ministry of Education/Community Development?

11. What makes your role in the organisation worthwhile? 


\section{CORPORATE SOCIAL RESPONSIBILITY IN THE MINING SECTOR IN ZAMBIA}

Questions for semi-structured interviews with District Education Planning Unit/Department, two teachers and the school manager.

1. What is the relationship between yourself and Barrick Gold with regards to access to education?

2. What are the communication arrangements between your office and Barrick Gold with regards to education projects?

3. How are education projects implemented by Barrick Gold? i.e. who decides what should be done? Which schools? Is it rehabilitation? Teacher support? Materials? Furniture?

4. What is the distribution of girls and boys attending school now? There are more boys than girls.

5. What was it before Barrick Gold started implementing this project?

6. What is your relationship with the school and community over project implementation?

7. What is working really well with regards to the education project and the support from the company?

8. If you would wish BG to do anything differently what would it be? 